\title{
Mean Circulation of the Upper Layers of the Western Equatorial Pacific Ocean
}

\author{
YVES GOURIOU \\ Institut Français de Recherche Scientifique pour le Développement en Coopération, \\ Institut Français de Recherche pour l'explotation de la Mer, Plouzané, France
}

\section{JOHN TOOLE}

Department of Physical Oceanography, Woods Hole Oceanographic Institution, Woods Hole, Massachussetts

\begin{abstract}
Hydrographic (0-1000 dbar) and direct current measurements $(0-600 \mathrm{dbar})$ along $165^{\circ} \mathrm{E}\left(20^{\circ} \mathrm{S}-10^{\circ} \mathrm{N}\right)$ between January 1984 and July 1991 are used to investigate the mean circulation and its relationships with the distributions of salinity and potential vorticity on isopycnal surfaces. Less well documented mean sections along $142^{\circ} \mathrm{E}$ and $137^{\circ} \mathrm{E}$ are used to complement the $165^{\circ} \mathrm{E}$ analysis. The Equatorial Undercurrent is centered on the equator at $165^{\circ} \mathrm{E}$ and on $0.5^{\circ} \mathrm{N}$ at $142^{\circ} \mathrm{E}$. No variation in its transport $\left(15.0 \times 10^{6} \mathrm{~m}^{3} \mathrm{~s}^{-1}\right)$ is found between those longitudes. We find indication of the Equatorial Undercurrent at $137^{\circ} \mathrm{E}-0.75^{\circ} \mathrm{N}$ in the geostrophic field. The northern and southern Subsurface Countercurrents are clearly identified by extrema of eastward velocity at $165^{\circ} \mathrm{E}$ around $3^{\circ} \mathrm{N}$ and $3^{\circ} \mathrm{S}(250 \mathrm{dbar})$. No evidence of a southern Subsurface Countercurrent is found at $142^{\circ} \mathrm{E}$, At $137^{\circ} \mathrm{E}$ the northem Subsurface Countercurrent is not characterized by a local extrema of eastward velocity: the North Equatorial Countercurrent seems to extend from the surface to 400 dbar with a southward shift of its core. Analysis of the seasonal variability at $165^{\circ} \mathrm{E}$ indicates that the Equatorial Undercurrent transport increases by a factor 2 between January $\left(10.7 \times 10^{6} \mathrm{~m}^{3} \mathrm{~s}^{-1}\right)$ and July $\left(21.5 \times 10^{6} \mathrm{~m}^{3} \mathrm{~s}^{-1}\right)$ and the Equatorial Intermediate Current transport is halved $\left(6.3 \times 10^{6} \mathrm{~m}^{3} \mathrm{~s}^{-1}\right.$ in January, $3.5 \times 10^{6} \mathrm{~m}^{3} \mathrm{~s}^{-1}$ in July). In contrast, the transport of the Subsurface Countercurrents does not vary substantially between those two months. The meridional distributions of salinity and potential vorticity show that the axes of the main eastward currents are associated with strong meridional property gradients, not with property extrema. The eastward currents thus represent a barrier to the northward extension of the high salinity Tropical Water. Relatively weak meridional gradients of salinity and potential vorticity are observed in the westward directed South Equatorial Current and Equatorial Intermediate Current.
\end{abstract}

\section{INTRODUCTION}

Increased scientific interest in the El Nino/Southern Oscillation (ENSO) phenomena has focussed researchers' attention on the western equatorial Pacific Ocean. The exchange of heat between the ocean and atmosphere (principally by evaporation) is thought to be key to ENSO. In turn, the latent heat flux depends critically on ocean temperature: evaporation can be intense when sea surface temperature is near $30^{\circ} \mathrm{C}$ as is typical of the western Pacific [W'ebster and Lukas, 1992]. In the past decade, an unprecedented number of oceanographic research cruises have been made in the western Pacific in support of the international Tropical Ocean Global Atmosphere program (TOGA). From an oceanographic viewpoint, these studies seek to define the processes controlling the warm water pool. In the following, a subset of these cruise data is used to deduce aspects of the mean upper ocean circulation, and to characterize its annual and interannual variability. Principal attention is paid to the zonal flow between longitudes $137^{\circ} \mathrm{E}$ and $165^{\circ} \mathrm{E}$ from $10^{\circ} \mathrm{N}$ to $20^{\circ} \mathrm{S}$.

The present study is novel in two ways. First, we construct average fields from 27 occupations of a transequatorial section at $165^{\circ} \mathrm{E}$ within a $71 / 2$ year period (Table 1 ). It is argued that the average fields estimated from this large data set are representative of the mean circulation. Second, each of these cruises

Copyright 1993 by the American Geophysical Union.

Paper number 93JC02513.

0148-0227/93/93JC - 02513\$05.00 (save one) made direct measurement of upper ocean velocity. We utilize these data to construct an average zonal velocity section, without resort to the thermal wind relation. Previously, shorter term, but temporally denser, velocity sections were obtained in the central equatorial Pacific (Hawaii-to-Tahiti shuttle experiment [Wyrtki and Kilonsky, 1984]; PEQUOD [Firing, 1987]). Here the velocity section is used to estimate transports of the major near-equatorial currents, as well as the meridional distribution of potential vorticity (including the relative vorticity term). Data along repeated meridional sections are also available farther east at $141.5^{\circ} \mathrm{E}-143^{\circ} \mathrm{E}$ and $137^{\circ} \mathrm{E}$. Average fields are estimated at these longitudes as well, and comparison is made to the circulation deduced at $165^{\circ} \mathrm{E}$. Our aim is to document the mean circulation in the western Pacific, characterize its relationship to the property distributions, and where possible, shed light on the dynamics of the flow.

The following section describes the data set and outlines our analysis procedures. Section 3 presents the mean sections, deferring discussion of variability to Section 4 and the uncertainty in the averaged fields to the appendix. General discussion and conclusions appear in section 5 .

\section{DATA AND METHODS}

In this study we used data collected along three longitudes in the western equatorial Pacific Ocean: $165^{\circ} \mathrm{E}, 141.5^{\circ}-143^{\circ} \mathrm{E}$, and $137^{\circ} \mathrm{E}$ (Figure 1). The focus of the $165^{\circ} \mathrm{E}$ analysis is the time interval January 1984 to July 1991. A much smaller data set is available about $141.5^{\circ}-143^{\circ} \mathrm{E}$, spanning the period July 1985 to June 1990. Complementary hydrographic data, obtained bian- 
TABLE 1. Dates and Latitudinal Extension of the 27 Cruises at $165^{\circ} \mathrm{E}$, With Method of Current Measurements

\begin{tabular}{|c|c|c|c|}
\hline Cruises & Dates & Latitudes & Current \\
\hline SURTROPAC 01 & $\operatorname{Jan} .10-20,1984$ & $20^{\circ} \mathrm{S}-7^{\circ} \mathrm{N}$ & Profiler \\
\hline SURTROPAC 02 & Aug. 5 - 15, 1984 & $20^{\circ} \mathrm{S}-7^{\circ} \mathrm{N}$ & Profiler \\
\hline SURTROPAC 03 & $\operatorname{Jan} 9-21,1985$ & $20^{\circ} \mathrm{S}-10^{\circ} \mathrm{N}$ & Profiler \\
\hline SURTROPAC 04 & 28 June - 09 July 1985 & $20^{\circ} \mathrm{S}-8^{\circ} \mathrm{N}$ & Protiler \\
\hline SURTROPAC 05 & $\operatorname{Jan} .10-21,1986$ & $20^{\circ} \mathrm{S}-10^{\circ} \mathrm{N}$ & Profiler \\
\hline US/PRC 01 & 30 Jan. - 5 Feb. 1986 & $6^{\circ} \mathrm{S}-10^{\circ} \mathrm{N}$ & \\
\hline SURTROPAC 06 & June $17-27,1986$ & $20^{\circ} \mathrm{S}-10^{\circ} \mathrm{N}$ & Profiler \\
\hline US/PRC 02 & Dec. $08-16,1986$ & $9^{\circ} \mathrm{S}-10^{\circ} \mathrm{N}$ & $\mathrm{ADCP}$ \\
\hline SURTROPAC 07 & Jan. $10-21,1987$ & $20^{\circ} \mathrm{S}-10^{\circ} \mathrm{N}$ & Profiler \\
\hline SURTROPAC 08 & July $2-15,1987$ & $20^{\circ} \mathrm{S}-10^{\circ} \mathrm{N}$ & Profiler \\
\hline TEW3 & July $20-26,1987$ & $5^{\circ} \mathrm{S}-8^{\circ} \mathrm{N}$ & $\mathrm{ADCP}$ \\
\hline PROPPAC 01 & Sep. $9-20,1987$ & $20^{\circ} \mathrm{S}-6^{\circ} \mathrm{N}$ & Profiler \\
\hline US/PRC 03 & Oct. $13-21,1987$ & $10^{\circ} \mathrm{S}-10^{\circ} \mathrm{N}$ & $\mathrm{ADCP}$ \\
\hline SURTROPAC 09 & Jan. $16-28,1988$ & $20^{\circ} \mathrm{S}-10^{\circ} \mathrm{N}$ & Profiler \\
\hline PROPPAC 02 & 28 March - 08 April 1988 & $20^{\circ} \mathrm{S}-6^{\circ} \mathrm{N}$ & Profiler \\
\hline US/PRC 04 & May $15-23,1988$ & $10^{\circ} \mathrm{S}-10^{\circ} \mathrm{N}$ & $\mathrm{ADCP}$ \\
\hline SURTROPAC 10 & June $14-27,1988$ & $20^{\circ} \mathrm{S}-10^{\circ} \mathrm{N}$ & Profiler \\
\hline PROPPAC 03 & Sep. $11-22,1988$ & $20^{\circ} \mathrm{S}-6^{\circ} \mathrm{N}$ & Profiler \\
\hline US/PRC 05 & Nov. $8-17,1988$ & $10^{\circ} \mathrm{S}-10^{\circ} \mathrm{N}$ & ADCP \\
\hline SURTROPAC 11 & Jan. $6-19,1989$ & $20^{\circ} \mathrm{S}-10^{\circ} \mathrm{N}$ & Profiler \\
\hline US/PRC 06 & May $14-23,1989$ & $10^{\circ} \mathrm{S}-10^{\circ} \mathrm{N}$ & $\mathrm{ADCP}$ \\
\hline SURTROPAC 12 & 29 June - 12 July 1989 & $20^{\circ} \mathrm{S}-10^{\circ} \mathrm{N}$ & Profiler \\
\hline US/PRC 07 & Nov. $12-20,1989$ & $10^{\circ} \mathrm{S}-10^{\circ} \mathrm{N}$ & ADCP \\
\hline SURTROPAC 13 & Dec. $15-26,1989$ & $16^{\circ} \mathrm{S}-8^{\circ} \mathrm{N}$ & Profiler \\
\hline US/PRC 08 & 24 June - 03 July 1990 & $10^{\circ} \mathrm{S}-10^{\circ} \mathrm{N}$ & $\mathrm{ADCP}$ \\
\hline SURTROPAC 14 & March $12-22,1991$ & $19^{\circ} \mathrm{S}-8^{\circ} \mathrm{N}$ & $\mathrm{ADCP}$ \\
\hline SURTROPAC 15 & July $19-28,1991$ & $19^{\circ} \mathrm{S}-10^{\circ} \mathrm{N}$ & ADCP \\
\hline
\end{tabular}

nually by the Japanese Meteorological Agency along $137^{\circ} \mathrm{E}$ between 1972 and 1985, are also examined.

\subsection{Cruise Summaries}

Four independent research programs made measurements along $165^{\circ} \mathrm{E}$ (Table 1 , Figure $2 a$ ). There were 15 cruises from the Surveillance Trans-Océanique du Pacifique (SURTROPAC) program led by the Institut Français de Recherche Scientifique pour le Developpement en Coopération (ORSTOM) group, based in Nouméa (New Caledonia). The first six of these (SURTROPAC 01-06) were described in a paper by Delcroix et al. [1987]: cruises 7 to 10 contributed to Delcroix et al.'s [1992] study of the 1987-1988 ENSO event. The SURTROPAC cruises were biannual, generally taking place in January and June-July. Beginning in 1987, the SURTROPAC program was complemented by the Production Pélagique dans le Pacifique (PROPPAC) program, also conducted by ORSTOM, Nouméa. PROPPAC cruises occurred in spring and fall. Sampling on these expeditions extended from $20^{\circ} \mathrm{S}$ to as far north as $10^{\circ} \mathrm{N}$ (Table 1). Stations were made every half degree of latitude between $3^{\circ} \mathrm{N}$ and $3^{\circ} \mathrm{S}$ (between $2^{\circ} \mathrm{N}$ and $2^{\circ} \mathrm{S}$ during the first seven cruises), and every degree of latitude poleward of $3^{\circ} \mathrm{N}$ and $3^{\circ} \mathrm{S}$ : The other major program of hydrography along $165^{\circ} \mathrm{E}$ in this time period was the United States/People's Republic of China (US/PRC) cooperative program for Air-Sea Interaction Studies in the tropical western Pacific. Eight cruises were completed between January 1986 and July 1990 on an irregular schedule (Table 1). Observations were made between $10^{\circ} \mathrm{S}$ and $10^{\circ} \mathrm{N}$; resolution was also every half degree of latitude between $3{ }^{\circ} \mathrm{N}$ and $3^{\circ} \mathrm{S}$, and every degree of latitude poleward of $3^{\circ} \mathrm{N}$ and $3^{\circ} \mathrm{S}$. It must be noted that the stations south of $7^{\circ} \mathrm{S}$ deviated west of the $165^{\circ} \mathrm{E}$ meridian. The southernmost station $\left(10^{\circ} \mathrm{S}\right)$ was generally made off the coast of the Solomon Islands at $163^{\circ} \mathrm{E}$ ( $162.5^{\circ} \mathrm{E}$ during US/PRC 2). This departure from the $165^{\circ} \mathrm{E}$ meridian is ignored in the present analysis. Finally, we included data from leg 3 of the Transports of Equatorial Waters (TEW) expedition [Mangum et al., 1991]. This cruise spanned the latitudes from $5^{\circ} \mathrm{S}$ to $8^{\circ} \mathrm{N}$ on $165^{\circ} \mathrm{E}$.

Two research programs occupied meridional sections at longitudes $141.5^{\circ} \mathrm{E}-143^{\circ} \mathrm{E}$ : the US/PRC and the Western Equatorial Pacific Ocean Circulation Study (WEPOCS) [Lindstrom et al., 1987]. For convenience in the following, we designate these sections as the $142^{\circ} \mathrm{E}$ line. Six sections were made along $141.5^{\circ} \mathrm{E}$ between the Papua New Guinea coast at $2.6^{\circ} \mathrm{S}$ and $9 \mathrm{~N}$ as part of the US/PRC program. Three sections were occupied

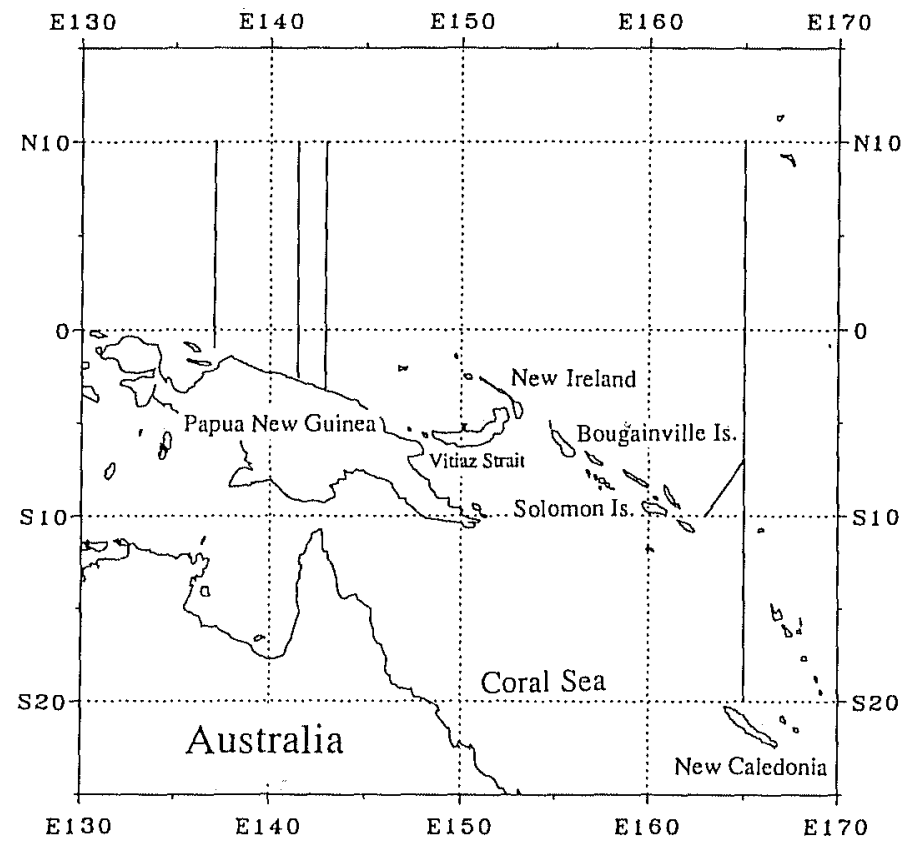

Fig. 1. Map of the western tropical Pacific and position of the meridional sections analy'zed $\left(165^{\circ} \mathrm{E}, 142^{\circ} \mathrm{E}, 137^{\circ} \mathrm{E}\right)$ (solid lines). 

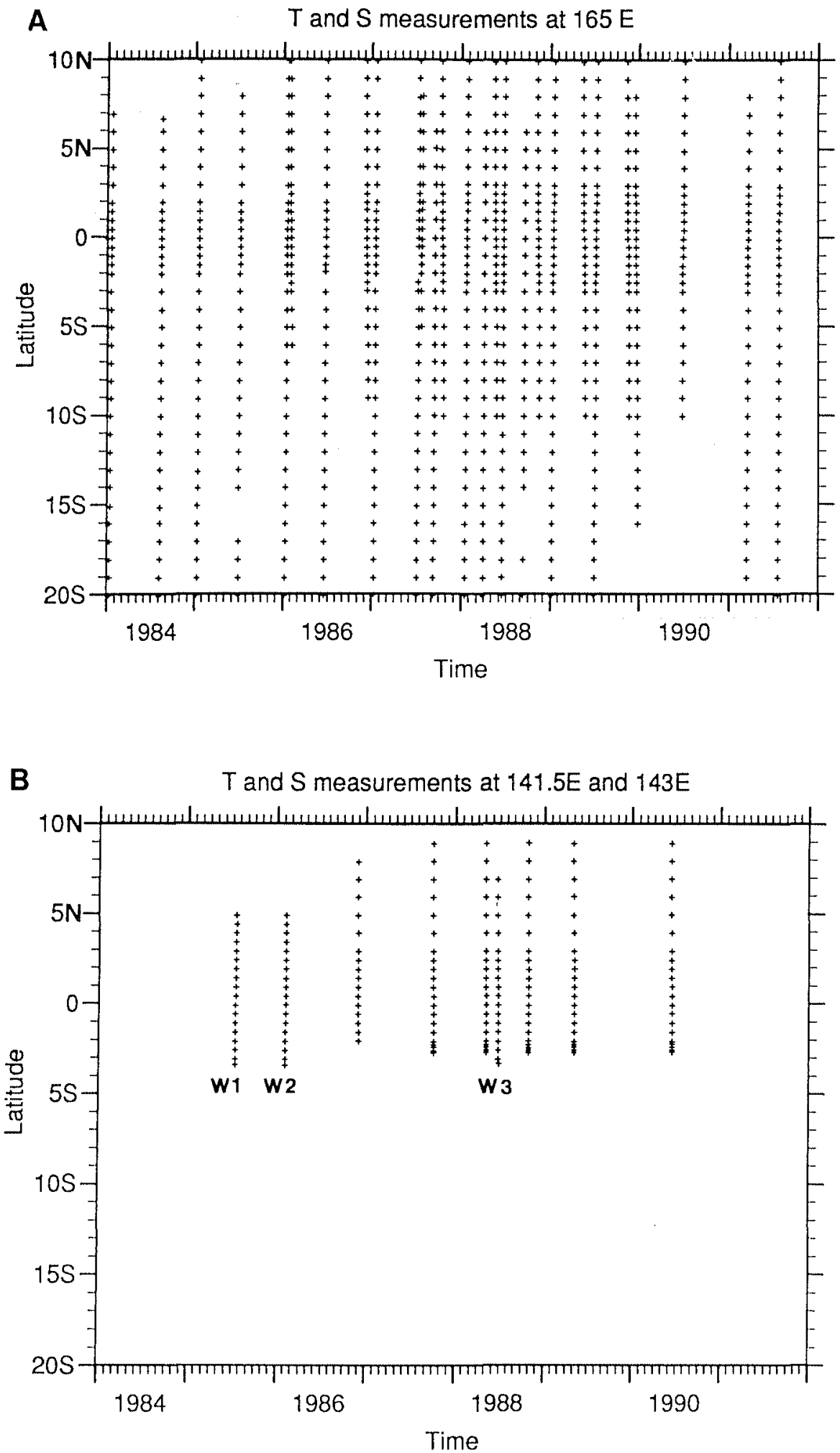

Fig. 2. Time-latitude plots of the hydrographic stations. (a) along $165^{\circ} \mathrm{E}$ and $(b)$ along $141.5^{\circ} \mathrm{E}$ and $143^{\circ} \mathrm{E}$. (W1, WEPOCS 01 ; W2, WEPOCS 02; W3, WEPOCS 03).

along $143^{\circ} \mathrm{E}$ between $3.30^{\circ} \mathrm{S}$ to at least $5^{\circ} \mathrm{N}$ as part of the WEPOCS program (Table 2, Figure $2 b$ ). US/PRC cruise 1 only sampled between the equator and $5^{\circ} \mathrm{N}$ along $141.5^{\circ} \mathrm{E}$ and did not contain direct velocity measurements, so is not included in the present analysis. Station spacing at $141.5^{\circ} \mathrm{E}$ was $0.5^{\circ}$ between $3^{\circ} \mathrm{N}$ and $2^{\circ} \mathrm{S}$, decreasing to approximately $30 \mathrm{~km}$ between $2^{\circ} \mathrm{S}$ and the coast. North of $3^{\circ} \mathrm{N}$, casts were made at whole degrees of latitude. The third meridian analyzed here, $137^{\circ} \mathrm{E}$, has been sampled by the Japan Meteorological Agency since 1967. Their observations extend north from New Guinea $\left(1^{\circ} \mathrm{S}\right)$ to the coast of Japan $\left(34^{\circ} \mathrm{N}\right)$. We only used the sections between 1972 and 1985 , as during that period two sections were made each year 
TABLE 2. Dates and Latitudinal Extension of the Nine Cruises at $141^{\circ} 30^{\circ} \mathrm{E}$ (US/PRC) and $143^{\circ} \mathrm{E}$ (WEPOCS)

\begin{tabular}{|c|c|c|c|}
\hline Cruises & Dates & L.atitudes & Current \\
\hline WEPOCS 01 & July $11-15,1985$ & $3.31^{\circ} \mathrm{S}-5^{\circ} \mathrm{N}$ & \\
\hline WEPOCS 02 & Feb. $4-07,1986$ & $3.32^{\circ} \mathrm{S}-5^{\circ} \mathrm{N}$ & $\mathrm{ADCP}$ \\
\hline US/PRC 02 & 28 Nov. - 1 Dec. 1986 & $2.00^{\circ} \mathrm{S}-8^{\circ} \mathrm{N}$ & \\
\hline US/PRC 03 & 30 Sep. -4 Oct. 1987 & $2.69^{\circ} \mathrm{S}-9^{\circ} \mathrm{N}$ & $\mathrm{ADCP}$ \\
\hline US/PRC (04 & May $3-6,1988$ & $2.71^{\circ} \mathrm{S}-9^{\circ} \mathrm{N}$ & $\mathrm{ADCP}$ \\
\hline WEPOCS 03 & June $21-26,1988$ & $3.23^{\circ} \mathrm{S}-7^{\circ} \mathrm{N}$ & $\mathrm{ADCP}$ \\
\hline US/PRC 05 & Oct. $26-29,1988$ & $2.70^{\circ} \mathrm{S}-9^{\circ} \mathrm{N}$ & $\mathrm{ADCP}$ \\
\hline US/PRC 06 & 30 April - 04 May 1989 & $2.70^{\circ} \mathrm{S}-9^{\circ} \mathrm{N}$ & $\mathrm{ADCP}$ \\
\hline US/PRC 08 & June $11-14,1990$ & $2.69^{\circ} \mathrm{S}-9^{\circ} \mathrm{N}$ & ADCP \\
\hline
\end{tabular}

(in January and July) and they covered the equatorial region to $1^{\circ} \mathrm{S}$. Half degree meridional resolution was achieved south of $8^{\circ} \mathrm{N}$, with $1^{\circ}$ spacing to the north.

\subsection{Hydrographic Data}

During the first five SURTROPAC cruises at $165^{\circ} \mathrm{E}$, conductivity, temperature, and depth (CTD) measurements were made with a Bisset-Bermann model 9040 STD probe. A SeaBird SBE model 9-02 CTD probe was utilized for the later SURTROPAC and the PROPPAC cruises. Temperature and salinity measurements were reduced to a 5 -dbar interval ( 2 dbar for SURTROPAC 14 and 15), as described by Delcroix et al. [1987, 1992]. EG\&G/Neil Brown Instrument System (NBIS) MKIIIb CTDs were employed by the US/PRC program. Profiles of temperature and salinity were reduced to a 2 -dbar interval as described by Cook et al. [1990] and Lake et al. [1991].'The early SURTROPAC expeditions sampled to $1000 \mathrm{dbar}$; subsequent cruises extended the measurements to about 2000 dbar. All US/PRC casts in the present study extended to at least $2000 \mathrm{dbar}$ or the ocean bottom where shallower, with approximately $1 / 3$ reaching below $3000 \mathrm{dbar}$. These deep-water potential temperature-salinity data were employed during data reduction to insure internal consistency of the US/PRC salinity data to better than 0.005 psu [Cook et al., 1990; Lake et al., 1991].

To assess the accuracy of each cruise's salinity data, $\theta-S$ diagrams at each latitude were plotted using all available stations. It appeared that for a given temperature (below $10^{\circ} \mathrm{C}$ ) the dispersion of the $\theta-S$ points was larger for the SURTROPACPROPPAC stations than for the US/PRC measurements. This dispersion was mainly due to the data of the first five SURTROPAC cruises. Comparisons on individual isotherms of salinity measured during those cruises and the mean salinity on those temperatures est mated from the US/PRC data did not show systematic bias. No simple correction was thus possible, and the data were accepted as they were. The quality of the more recent salinity measurements is generally much improved, the exceptions being SURTROPAC 8, PROPPAC 1 , and PROPPAC 3 . Systematic bias was found between salinity measured during those cruises and the average US/PRC salinities: -0.018 (standard deviation (s.d.) of 0.003 ) on the $3^{\circ} \mathrm{C}$ isotherm during SURTROPAC $8,-0.018$ (s.d. 0.005) on the $5^{\circ} \mathrm{C}$ isotherm during PROPPAC 1, and of -0.034 (s.d. 0.003) on the $5^{\circ} \mathrm{C}$ isotherm for PROPPAC 3 (negative differences denote salinities less than the US/PRC values). Arguing that these differences represented instrumental errors, simple bias corrections (given above) were applied to the respective salinity profiles of each cruise, yielding an internally consistent data set. During the WEPOCS cruises, hydrographic measurements were made with MKIII CTD probes. The first two cruises of this program were analyzed by Tsuchiya et al. [1989]. Comparisons between the two sets of measurements, and with the US/PRC data from the same area did not reveal significant salinity biases. These data were analyzed as reported. All of the WEPOCS profiles extend to the ocean bottom; the US/PRC casts all reach deeper than $2000 \mathrm{dbar}$ (or the bottom where shallower). The Japan Meteorological Agency cruises at $137^{\circ} \mathrm{E}$ obtained discrete water sample measurements every $20-50 \mathrm{~m}$ between the surface and $250 \mathrm{~m}$; spacing was $100-200 \mathrm{~m}$ to a depth of $1000-1500 \mathrm{~m}$. Casts were generally not deeper than $600 \mathrm{~m}$ at the half degree latitudes (i.e., $0.5^{\circ} \mathrm{S}$, $\left.0.5^{\circ} \mathrm{N}, 1.5^{\circ} \mathrm{N}, \ldots 7.5^{\circ} \mathrm{N}\right)$. Those cruises have recently been analyzed in Qiu and Joyce [1992], where details can be found about the validation of the data.

\subsection{Velocity}

Upper ocean velocity profiles were obtained by each of the cruises analyzed here (except along $137^{\circ} \mathrm{E}$ ). The SURTROPAC (1-14) and PROPPAC expeditions utilized an Aanderaa-Tareq profiling current meter (PCM) [Düing and Johnson, 1972] free falling along a cable under a drifting buoy. The measurements were referenced to the velocity at $600 \mathrm{~m}$ measured by a current meter placed at the lower end of the cable [Delcroix et al., 1987]. An Acoustic Doppler Current Profiler (ADCP) was used during SURTROPAC 14 and 15; the ship was equipped with an RD Instruments $150-\mathrm{kHz}$ system. For SURTROPAC 14, where both velocity measurement systems were employed, Delcroix et al. [1991] report differences between PCM velocity profiles relative to $600 \mathrm{~m}$ and ADCP absolute velocities of order $10 \mathrm{~cm}$ $\mathrm{s}^{-1}$, randomly distributed with latitude. ADCP sampling extended to $250 \mathrm{dbar}$ on SURTROPAC 14 and $350 \mathrm{dbar}$ during SURTROPAC 15. ADCP instruments (RD Instruments $150-\mathrm{kHz}$ profilers) were also used on the US/PRC, WEPOCS, and TEW-3 programs. At $165^{\circ} \mathrm{E}$, the US/PRC system sampled the water column from $20 \mathrm{~m}$ to $270 \mathrm{~m}$ (cruise 2), $320 \mathrm{~m}$ (cruise 3), $340 \mathrm{~m}$ (cruise 4), $400 \mathrm{~m}$ (cruise 5), $420 \mathrm{~m}$ (cruise 6, 7, 8). Thus, the Equatorial Undercurrent was always entirely sampled, but not so the Equatorial Intermediate Current beneath (cruises 2, 3, and 4 only partially sampled the Equatorial Intermediate Current). The maximum error in these data was estimated to be $7 \mathrm{~cm} \mathrm{~s}^{-1}$ for the zonal component of velocity [Delcroix et al., 1992].

These direct current measurements were not reliable close to the surface, whatever the method used. In the case of the PCM, the measurements are only valid once the buoy-cable system reaches its equilibrium position, at which time the profiling current meter is 5 or $10 \mathrm{~m}$ below the sea surface [Delcroix et al., 1987]. Ship keel depth plus acoustic blanking period limit ADCP measurements to depths greater than $20 \mathrm{~m}$, and sometimes $30 \mathrm{~m}$ [Bahr et al., 1989]. In the following, velocities have been extrapolated to the surface using the first reliable measurement, generally at $20 \mathrm{~m}$. To compute the transport of the main current, we integrated the velocity profiles, neglecting all 
velocities less than $2.5 \mathrm{~cm} \mathrm{~s}^{-1}$, which is the sensitivity threshold of the current meter used in the PCM system [Delcroix et al., 1987]. We used the same threshold to compute the geostrophic transport and the transport stream functions. No direct velocity measurements are available at $137^{\circ} \mathrm{E}$; the averaged hydrographic data were utilized to estimate the zonal geostrophic currents. Geostrophic velocity sections were also estimated for the averaged sections at 142 and $165^{\circ} \mathrm{E}$ for comparison with the directly measured currents. We determined the vertical profile of eastward velocity at the equator from the second derivative of the geostrophic relationship between $1^{\circ} \mathrm{N}$ and $1^{\circ} \mathrm{S}$ [Hayes, 1982].

\subsection{Averaging Procedures}

We constructed average sections based on the repeated hydrographic/velocity measurements. The study is limited to physical parameters, velocity, temperature, and salinity, and those quantities derived from them. As nearly all stations used in this study extended to $1000 \mathrm{dbar}$, but a significant number did not go deeper, the present study focuses on the upper kilometer of the water column. (The principle exceptions are the half degree stations along $137^{\circ} \mathrm{E}$; see above. These temperature and salinity profiles were extended in depth by horizontal linear interpolation between the adjacent stations.) The averaged sections were constructed at the resolution of the original data noted above. When a station on a particular cruise was missing, temperature, salinity, and velocity were linearly interpolated between adjacent stations when they were not more distant than $2^{\circ}$ of latitude. Larger gaps were simply left; averages at those latitudes were based on a reduced number of casts (Figure 2).

The equatorial pycnocline is characterized by huge vertical gradients. At a given latitude, slight variation in the depth of the pycnocline leads to significant variation of properties at a given pressure. In order to limit the artificial smoothing of features in the vertical obtained when averaging on pressure surfaces, we performed the averaging on potential density surfaces. The concept of averaging on isopycnals breaks down near the surface, where significant temporal variability was observed (caused by air-sea heat and freshwater exchange, wind stress, etc.). Some isopycnals were present only intermittently, and the surface mixed layer properties changed markedly with time. Our averaging procedure at each latitude was to first estimate the mean depth and properties (temperature, salinity, velocity) of the mixed layer (where the base of the mixed layer on individual stations was defined by the potential density anomaly surface $0.1 \mathrm{mg} \mathrm{cm}^{-3}$ greater than the surface value). The average property profiles were then derived by linear interpolation between the average mixed layer base and the first isopycnal surface which was sampled on every cruise. Then the averaged properties on isopycnals were linearly interpolated onto pressure surfaces with a 5-dbar vertical resolution.

Differences between averaging on density surfaces versus on pressure surfaces are seen mainly in the temperature and density fields. The mean vertical temperature gradient within the thermocline (and $\mathrm{N}^{2}$ ) is on average 1.2 times greater (1.1 for $\mathrm{N}^{2}$ gradient) when the averaging is performed on density surfaces (this will prove important for our subsequent analysis of the meridional distribution of potential vorticity). Furthermore, the standard deviations of the temperature fluctuations on density surfaces about the mean $165^{\circ} \mathrm{E}$ section are approximately $0.25^{\circ} \mathrm{C}$ in the thermocline and smaller below. The corresponding analysis on pressure surfaces returns standard deviations greater than $1^{\circ} \mathrm{C}$. The latter signal derives principally from vertical dis- placements of the thermocline. Maximum standard deviations are found around $3^{\circ} \mathrm{N}$ and $3^{\circ} \mathrm{S}$ at $200 \mathrm{dbar}$, where values are greater than $3^{\circ} \mathrm{C}$. The mean salinity fields derived by the two schemes are quite comparable. The high-salinity Tropical Water cores are perhaps more narrowly confined in the vertical when averaging is done on density surfaces. As was noted with temperature, greater variability about the mean is found on pressure surfaces (s.d. 0.2 psu) than on density surfaces (s.d. 0.1 psu). No differences were discerned between averaging methods for the mean velocity field or measures of the velocity variability.

The sections at $165^{\circ} \mathrm{E}$ were not evenly distributed during the period 1984-1991 (Figure 2a). Sampling was dense in 1988. Outside this period there were generally at least two sections per year (one in January, the other in July); the exception was 1990 when only one cruise occurred. In order not to bias the average toward years where there were more cruises, the sections were first grouped into 6-month intervals each year: October to April, and May to September. In the remainder of this paper we will refer to the October-April period as "January" and use "July" for the period May-September. This division allows representation, albeit crudely, of the seasonal cycle.

The mean velocity section was obtained by straightforward combination of the PCM measurements referenced to $600 \mathrm{dbar}$, and the absolute ADCP measurements. No attempt was made to change the reference of the PCM measurements. Away from the equator, geostrophic calculations relative to a deep pressure level (e.g., $1000 \mathrm{dbar}$ ) suggest the mean velocity at $600 \mathrm{dbar}$ in the tropical Pacific is small, about $5 \mathrm{~cm} \mathrm{~s}^{-1}$ or less. Thus we believe the present mean velocity section and gradient of this field (such as the relative vorticity) are reasonably accurate. More problematic are transport figures where velocity biases, if they are correlated over a few degrees of latitude, could introduce large errors. It will be shown that geostrophic transport estimates for the main currents, except for the South Equatorial Current, relative to $600 \mathrm{dbar}$ and to 1000 dbar differ by less than $10 \%$. This result indicates that the mixing of the ADCP and PCM measurements does not significantly bias the transport estimates for the extraequatorial currents.

Construction of the section north of Papua New Guinea involved merging measurements from two longitudes, $141.5^{\circ} \mathrm{E}$ and $143^{\circ} \mathrm{E}$ (done to increase the number of sections in the average). Neglect of differences over a few degrees of longitude is typically easy to justify given the long zonal scales of the equatorial circulation, but is more problematic close to the nonzonal New Guinea coast, where there is a strong subsurface current, the New Guinea Coastal Undercurrent [Tsuchiya et al., 1989]. The WEPOCS sections $\left(143^{\circ} \mathrm{E}\right)$ extended to $3.5^{\circ} \mathrm{S}$ while the US/PRC cruises $\left(141.5^{\circ} \mathrm{E}\right)$ reached $2.6^{\circ} \mathrm{S}$ (both were to shallow water at the coast). Not having a simple way to correct for the coastline, we simply averaged the sections against latitude to $2.6^{\circ} \mathrm{S}$ and estimated the error in the mean due to the truncation of the WEPOCS sections. The westward transport between the potential density anomaly surfaces 23.5 and $26.4 \mathrm{mg} \mathrm{cm}^{-3}$, which includes the main core of the Coastal Undercurrent (the circulation in that layer will be examined later in this paper), was summed from the coast to $0.5^{\circ} \mathrm{S}$, the northern limit of the Coastal Undercurrent. The transport was $12.1 \times 10^{6} \mathrm{~m}^{3} \mathrm{~s}^{-1}$ during WEPOCS 02 (February 1986) and $12.8 \times 10^{6} \mathrm{~m}^{3} \mathrm{~s}^{-1}$ during WEPOCS 03 (June 1988). From the coast to $2.6^{\circ} \mathrm{S}$, the transport was $5.2 \times 10^{6} \mathrm{~m}^{3} \mathrm{~s}^{-1}$ during WEPOCS 02 and $4.0 \times 10^{6} \mathrm{~m}^{3} \mathrm{~s}^{-1}$ during WEPOCS 03 . Truncation at $2.6^{\circ} \mathrm{S}$ thus misses $43 \%$ of the New Guinea Coastal Undercurrent transport during WEPOCS 02 and $31 \%$ during WEPOCS 03 , which in turn leads to an under- 
estimation here of the mean Coastal Undercurrent transport. However, since there were many more sections at $141.5^{\circ} \mathrm{E}$ than $143^{\circ} \mathrm{E}$, the error is not gross. Based on our averaged section, the transport from $2.6^{\circ} \mathrm{S}$ to $0.5^{\circ} \mathrm{S}$, between the 23.5 and $26.4 \mathrm{mg}$ $\mathrm{cm}^{-3}$ potential density anomaly surfaces is $11.2 \times 10^{6} \mathrm{~m}^{3} \mathrm{~s}^{-1}$. Had we somehow included the transport from the WEPOCS stations south of $2.6^{\circ} \mathrm{S}$, the mean transport figure would have been $12.5 \mathrm{x}$ $10^{6} \mathrm{~m}^{3} \mathrm{~s}^{-1}$

As there were not enough cruises along these longitudes to warrant grouping by season, we simply averaged all the sections. The US/PRC 04 and WEPOCS 03 cruises were quite close together in time (Table 2). These were combined prior to forming the average. Visually, a slight bias towards cruises in boreal summer is suggested (Figure $2 b$ ), but we have no quantitative measure of the error in the mean that is incurred. Furthermore the $142^{\circ} \mathrm{E}$ average north of $5^{\circ} \mathrm{N}$ is suspect, as only six cruises made hydrographic measurements and only five cruises made ADCP measurements north of this latitude. In contrast, the Japan Meteorological Agency cruises sampling at $137^{\circ} \mathrm{E}$ was very regular. Separate averaging of the January and July cruise data was performed, as well as estimation of the overall mean.

\section{MEAN FIELDS}

\subsection{Temperature and Salinity}

The temperature and salinity distributions in the west Pacific have been extensively discussed by many authors. Most recently, mean sections along $165^{\circ} \mathrm{E}$ were presented by, Delcroix et al. [1987] and Toole et al. [1988], and along $137^{\circ} \mathrm{E}$ by Qiu and Joyce [1992]. Here we focus principally on the differences in the temperature and salinity fields between $165^{\circ} \mathrm{E}, 142^{\circ} \mathrm{E}$, and $137^{\circ} \mathrm{E}$. The mean sea surface temperature is above $29^{\circ} \mathrm{C}$ from $10^{\circ} \mathrm{S}$ to $6^{\circ} \mathrm{N}$ at $165^{\circ} \mathrm{E}$ (Figure $3 a$ ), and from the New Guinea coast to $2.5^{\circ} \mathrm{N}$ at $137^{\circ} \mathrm{E}$ (Figure $4 a$ ). The average temperature section at $142^{\circ} \mathrm{E}$ (Figure $5 \mathrm{a}$ ), shows $29^{\circ} \mathrm{C}$ water extending to $9^{\circ} \mathrm{N}$. This extreme northward extent probably reflects the seasonal bias of the cruises to boreal summer. The standard deviation of the temperature fluctuations at $165^{\circ} \mathrm{E}$ about the mean is maximum at the surface; greater than $0.5^{\circ} \mathrm{C}$ at the equator, increasing to $1.5^{\circ} \mathrm{C}$ at $20^{\circ} \mathrm{S}$. The increase of the sea surface temperature variance away from the equator probably reflects the amplitude of the seasonal air-sea heat exchange (chiefly the solar heating cycle whose amplitude increases with latitude). As noted earlier, below $200 \mathrm{dbar}$, the temperature standard deviations are less than $0.25^{\circ} \mathrm{C}$. At the equator, the spreading of the thermocline, which indicates the presence of the Equatorial Undercurrent, is visible at $165^{\circ} \mathrm{E}$ and $142^{\circ} \mathrm{E}$, but not clearly so at $137^{\circ} \mathrm{E}$. The baroclinic gradients associated with the northern Subsurface Countercurrent around $3^{\circ} \mathrm{N}$ are seen at all three longitudes (note the depth of the $10^{\circ} \mathrm{C}$ isotherm for example). Owing to the proximity of New Guinea to the equator, evidence of the southern counterpart is apparent only at $165^{\circ} \mathrm{E}$.

The main pattern in the mean salinity field is the tongue of high salinity around 150 dbar (Figures $3 b, 4 b, 5 b$ ). Following Tsuchiya et al. [1989], we refer to this water mass as Tropical Water, as it originates at the surface around the tropic of Capricorn in the South Pacific. The salinity maximum of the northern Tropical Water just appears on these figures at $9^{\circ}-10^{\circ} \mathrm{N}$ (around $110 \mathrm{dbar}$ ). At $165^{\circ} \mathrm{E}$, the southern Tropical Water exhibits a salinity extremum around $13^{\circ} \mathrm{S}(35.841$ psu, s.d. 0.071 at $155 \mathrm{dbar}$, with a hint of another at $6^{\circ} \mathrm{S}(35.817$ psu, s.d. 0.134 at 170 dbar), more evident in property plots on density anomaly surfaces (Figure 6). The difference between the maximum value at $13^{\circ} \mathrm{S}$ and the relative minimum at $9^{\circ} \mathrm{S}$ (35.765 psu, s.d. 0.108 at $155 \mathrm{dbar}$ ) is significant at the 0.05 level, but not so the difference between the relative minimum at $9^{\circ} \mathrm{S}$ and the second maximum at $6^{\circ} \mathrm{S}$. The maximum salinity at $142^{\circ} \mathrm{E}$ and $137^{\circ} \mathrm{E}$ occurs at the New Guinea coast, where values are about 35.5 psu. Tsuchiya et al. [1989] show how high-salinity influence is carried westward from the Vitiaz Strait by the New Guinea Coastal Undercurrent. Using nutrient data on the $300 \mathrm{cl} \mathrm{t}^{-1}$ (centiliters per ton; equivalent to $10^{-8} \mathrm{~m}^{3} \mathrm{~kg}^{-1}$ ) surface (between $180 \mathrm{dbar}$ and $200 \mathrm{dbar}$ ), this group argued that the salty waters in the Coastal Undercurrent come from the Solomon Sea. Tropical Water in the Solomon Sea on that surface was higher in oxygen, and lower in phosphate, silica, and nitrate than the waters north of Bougainville Island and New Ireland. Thus, even though the salt content of the Tropical Water at $165^{\circ} \mathrm{E}$ is comparable to that in the Coastal Undercurrent, a direct, zonal, flow path connecting these apparently does not exist.

The distribution of salinity in the upper $50 \mathrm{~m}$ at $165^{\circ} \mathrm{E}$ exhibits a local maximum at $3^{\circ} \mathrm{S}$ (salinity $>34.5$ psu between $5^{\circ} \mathrm{S}$ and $3^{\circ} \mathrm{N}$ ). This could be the result of equatorial upwelling; $165^{\circ} \mathrm{E}$ lies at the western edge of the easterly trade winds. The maximum might also be the indirect consequence of the precipitation excess over evaporation under the atmospheric convergence zones, which give rise to the low surface salinities about $8 \% \mathrm{~N}$ and $10^{\circ} \mathrm{S}$ [Philander, 1990]. Farther west the equatorial salinity maximum is less well developed, and appears centered around $2^{\circ} \mathrm{N}$. The low values in the south at $142^{\circ}$ and $137^{\circ} \mathrm{E}$ are probably associated with river runoff from New Guinea. The winds here are monsoonal, and so equatorial upwelling is likely to be less important than farther east. Apparently the tendency for coastal upwelling to introduce high salinity into the surface waters is overcome by precipitation and runoff in the mean.

\subsection{Velocity}

The average zonal velocity fields at the three meridians find the North Equatorial Countercurrent between the equator and $9^{\circ} \mathrm{N}\left(7^{\circ} \mathrm{N}\right.$ at $\left.137^{\circ} \mathrm{E}\right)$ with a maximum velocity between 4 and $6^{\circ} \mathrm{N}$ (Figures $3 c, 4 c, 5 c$ ). This eastward surface flow is contiguous with the subsurface eastward Equatorial Undercurrent and the northern Subsurface Countercurrent. North of the surface Countercurrent, the southern edge of the North Equatorial Current was sampled. The westward directed South Equatorial Current extends in the averaged field at $165^{\circ} \mathrm{E}$ from the equator to $6^{\circ} \mathrm{S}$. Eastward flow was also found between $6^{\circ} \mathrm{S}$ and $11^{\circ} \mathrm{S}$, the South Equatorial Countercurrent, with maximum velocity between $8^{\circ} \mathrm{S}$ and $9^{\circ} \mathrm{S}$. This current lies between the two salinity extrema of the southern Tropical Water, suggesting zonal advection plays a role in defining the salinity distribution. Between $11^{\circ} \mathrm{S}$ and $14^{\circ} \mathrm{S}$, a second branch of the westward directed South Equatorial Current is found with maximum speed $\left(>10 \mathrm{~cm} \mathrm{~s}^{-1}\right.$ ) subsurface. Still farther south, the mean velocity section shows yet another band of eastward flow. This current was first described by Merle et al. [1969], who estimated its mean latitude to be $17.5^{\circ} \mathrm{S}$ on the basis of nine cruises between December 1965 and May 1968 along $170^{\circ} \mathrm{E}$. They called the flow the South Tropical Countercurrent. Kessler and Taft [1987] argued that this eastward current was part of the southern subtropical gyre [see Wyrtki, 1975]. As the present data sets at $142^{\circ}$ and $137^{\circ} \mathrm{E}$ do not extend this far south, we can shed no light on the westward extent of these zonal surface currents. 

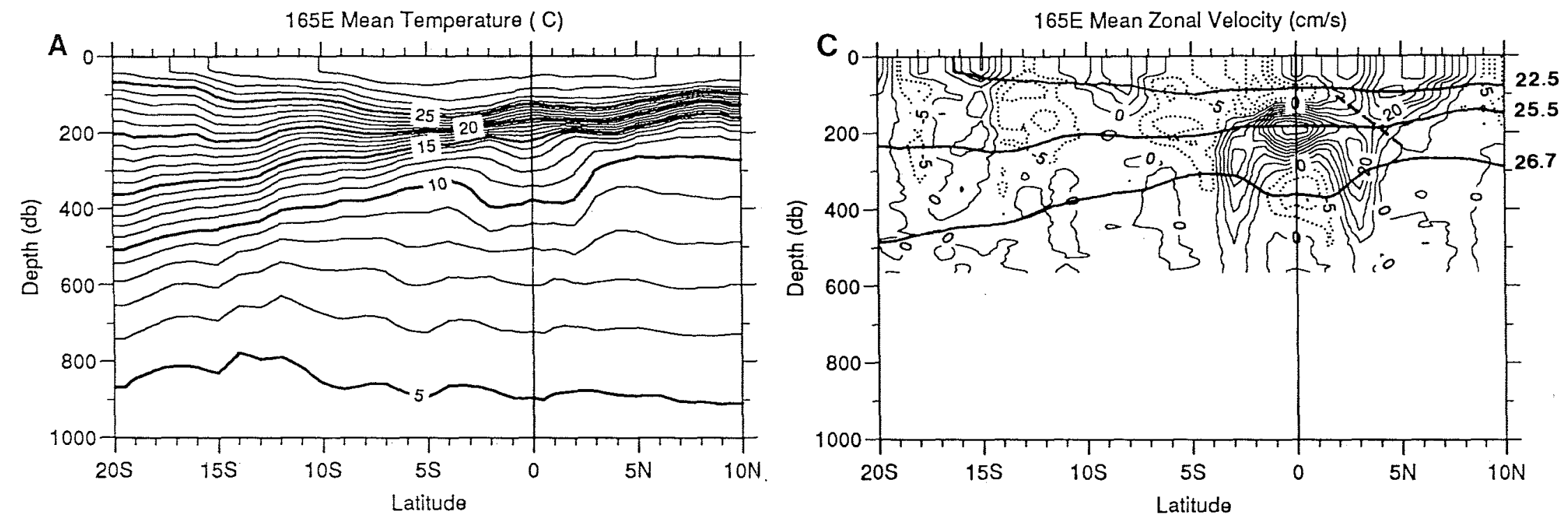

165E Mean Salinity (psu)
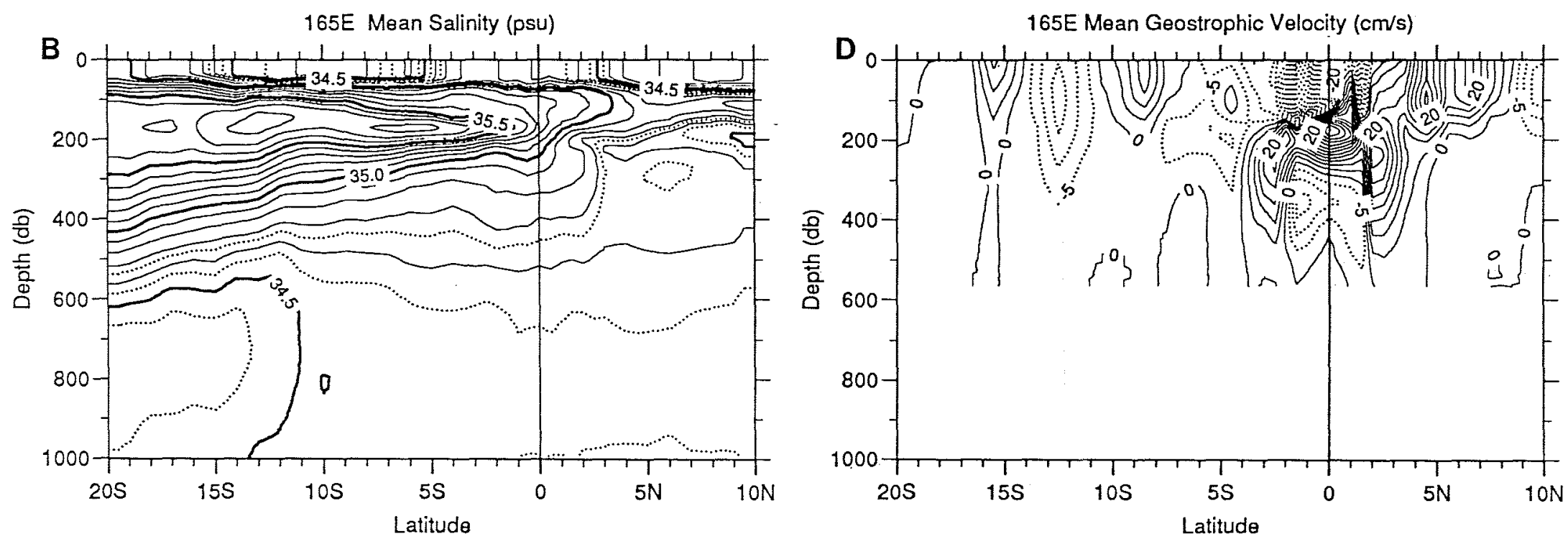

Fig. 3. Mean meridional sections of $(a)$ temperature in ${ }^{\circ} \mathrm{C},(b)$ salinity in psu, and $(c)$ zonal velocity in $\mathrm{cm} \mathrm{s}^{-1}$ along $165^{\circ} \mathrm{E}$. The zonal geostrophic velocity relative to $600 \mathrm{dbar}$ calculated from the data in Figure $3 a$ and Figure $3 b$ appears in Figure $3 d$. Solid contours denote eastward flow. Isopycnal surfaces used in this paper are drawn in figure $3 c$ : sigma-theta $22.5,25.5,26.7 \mathrm{mg} \mathrm{cm}^{-3}$. 

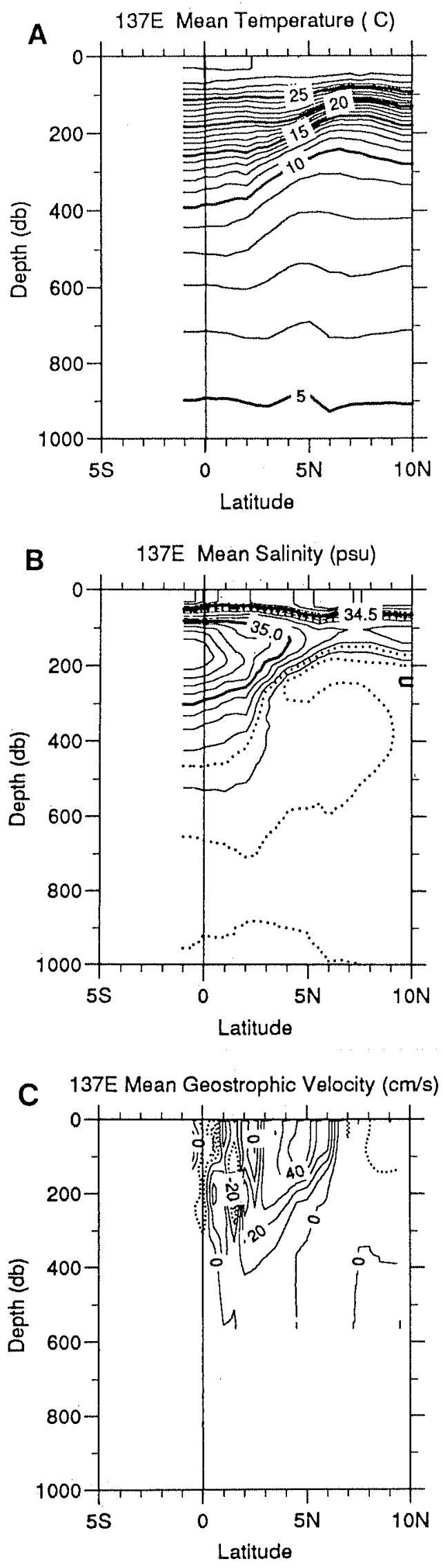

Fig. 4. Mean meridional sections of $(a)$ temperature in ${ }^{\circ} \mathrm{C}$ and $(b)$ salinity in psu along $137^{\circ} \mathrm{E}$. The zonal geostrophic velocity relative to $600 \mathrm{dbar}$ calculated from the data in Figure $4 a$ and Figure $4 b$ appears in Figure $4 c$. Solid contours denote eastward flow.
Subsurface, the principle currents in the study region are located between $4^{\circ} \mathrm{N}$ and $4^{\circ} \mathrm{S}$ (or the New Guinea coast). The Equatorial Undercurrent at $165^{\circ} \mathrm{E}$ lies on average between $2 \%$ and $2^{\circ} \mathrm{S}$ from $100 \mathrm{dbar}$ to $300 \mathrm{dbar}$. The velocity extremum, with mean speed of $48 \mathrm{~cm} \mathrm{~s}^{-1}$ (s.d. $15 \mathrm{~cm} \mathrm{~s}^{-1}$ ), is positioned on the equator. The $165^{\circ} \mathrm{E}$ average velocity field includes a section in October 1987, US/PRC 03, during which the Equatorial Undercurrent disappeared and was replaced by westward currents, and a cruise in May 1988 in which the Equatorial Undercurrent core speed exceeded $90 \mathrm{~cm} \mathrm{~s}^{-1}$ [McPhaden et al., 1990; Delcroix et al., 1992]. Our average core speed agrees very well with the mean derived from the long-term equatorial current meter mooring at this meridian: $46.9 \mathrm{~cm} \mathrm{~s}^{-1}$ (s.d. $7.7 \mathrm{~cm} \mathrm{~s}^{-1}$ ) for the period January 1986 to January 1992, at the mean core depth $(200 \mathrm{~m})$ of the Equatorial Undercurrent [McCarty and McPhaden, 1993]. On the flanks of the Equatorial Undercurrent, extending to greater depths, are the Subsurface Countercurrents, positioned quite symmetrically about the equator at $165^{\circ} \mathrm{E}$. Maximum velocity is higher in the northern jet $\left(27 \mathrm{~cm} \mathrm{~s}^{-1}\right.$ at $2.5^{\circ} \mathrm{N}$, s.d. $\left.11 \mathrm{~cm} \mathrm{~s}^{-1}\right)$ than the southern $\left(22 \mathrm{~cm} \mathrm{~s}^{-1}\right.$ at $2.5^{\circ} \mathrm{S}$, s.d. $12 \mathrm{~cm} \mathrm{~s}^{-1}$ ). Below the Equatorial Undercurrent we find the Equatorial Intermediate Current [Delcroix and Hénin, 1988] with westward speeds in excess of $10 \mathrm{~cm} \mathrm{~s}^{-1}$. This flow is located between $2^{\circ} \mathrm{N}$ and $2^{\circ} \mathrm{S}$, at depths from 300 to $500 \mathrm{dbar}$; the mean field has a speed maximum of $15 \mathrm{~cm} \mathrm{~s}^{-1}$ at $0.5^{\circ} \mathrm{N}$ (s.d. 12 $\left.\mathrm{cm} \mathrm{s}^{-1}\right)$. Only five ADCP profiles out of the 10 available extend to 450 dbar and sample the entire extent of the Equatorial Intermediate Current.

The standard deviations of the velocity fluctuations about the mean $165^{\circ} \mathrm{E}$ velocity section are everywhere larger than $5 \mathrm{~cm} \mathrm{~s}^{-1}$ with values greater than $20 \mathrm{~cm} \mathrm{~s}^{-1}$ above $100 \mathrm{dbar}$. Maximum variability is found between $2^{\circ} \mathrm{N}$ and $2^{\circ} \mathrm{S}$ (s.d. $>30 \mathrm{~cm} \mathrm{~s}^{-1}$ ) with standard deviations greater than $40 \mathrm{~cm} \mathrm{~s}^{-1}$ between $1^{\circ} \mathrm{N}$ and $1^{\circ} \mathrm{S}$ in the top $90 \mathrm{dbar}$. Given the propensity for westerly wind burst activity in this region, local wind forcing is thought to be responsible for much of the variability on the equator. The contoured field of velocity variance shows a relative maximum at the equator at the level of the Undercurrent $\left(15-20 \mathrm{~cm} \mathrm{~s}^{-1}\right)$, decreasing to about $10 \mathrm{~cm} \mathrm{~s}^{-1}$ in the Intermediate Current and 5-15 $\mathrm{cm} \mathrm{s}^{-1}$ in Subsurface Countercurrents. That higher variability was found within the equatorial wave guide is not a surprise.

In comparison to $165^{\circ} \mathrm{E}$, the Equatorial Undercurrent along $142^{\circ} \mathrm{E}$ is displaced to the north; the velocity core is centered on $0.5^{\circ} \mathrm{N}$ with an average maximum speed of $51 \mathrm{~cm} \mathrm{~s}^{-1}$ at $230 \mathrm{dbar}$ (s.d. $12.1 \mathrm{~cm} \mathrm{~s}^{-1}$ ). The northern Subsurface Countercurrent is again characterized by a velocity maximum distinct from the Equatorial Undercurrent, but no separate eastward velocity core is found to the south within the depth interval sampled by the ADCP. As noted earlier, the mean temperature section (Figure $5 a$ ) south of the equator at these and greater depths is relatively flat (no downward slope of isotherms toward the equator is apparent below the thermocline as seen at $165^{\circ} \mathrm{E}$ ). South of $1^{\circ} \mathrm{S}$, the thermocline depth flow is strongly westward with a maximum velocity of $59 \mathrm{~cm} \mathrm{~s}^{-1}$ at $2.17^{\circ} \mathrm{S}$, at $200 \mathrm{dbar}$ (s.d. $11 \mathrm{~cm}$ $\mathrm{s}^{-1}$ ). This is the New Guinea Coastal Undercurrent described by Tsuchiya et al. [1989]. Somewhat shallower, a second core of westward flow $\left(1^{\circ} \mathrm{S}, 100 \mathrm{dbar}, 34 \mathrm{~cm} \mathrm{~s}^{-1}\right)$ appeared in the mean field. This subsurface maximum of westward velocity is observed on the individual sections between 50 dbar and $100 \mathrm{dbar}$, from $3^{\circ} \mathrm{N}$ to $1^{\circ} \mathrm{S}$ (except during WEPOCS 03 and USPRC 03).

The ADCP measurements did not in general extend deep enough to sample the Equatorial Intermediate Current at $142^{\circ} \mathrm{E}$. Westward flow was observed under the Undercurrent at $142^{\circ} \mathrm{E}$ 

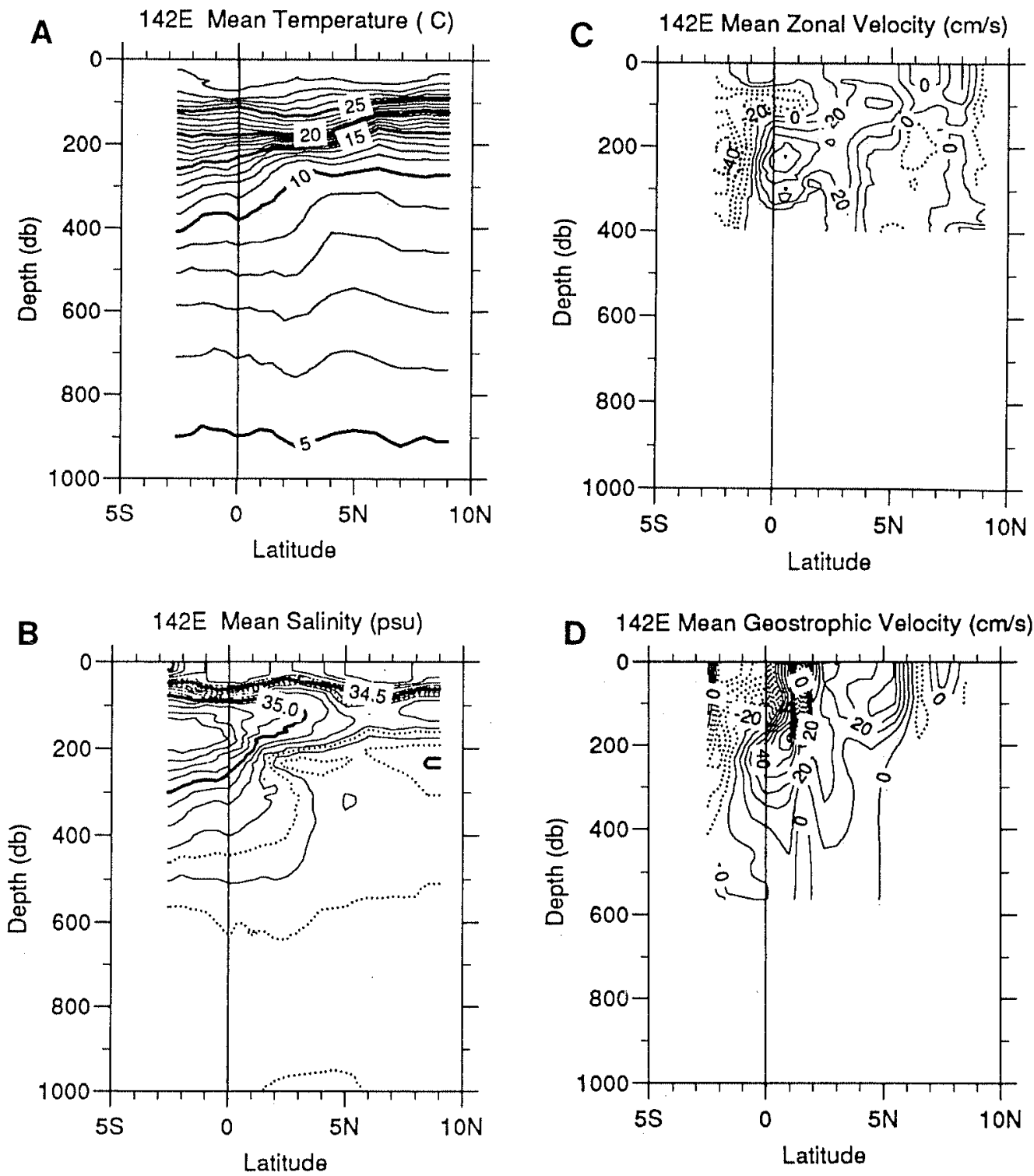

Fig. 5. Mean meridional sections of $(a)$ temperature in ${ }^{\circ} \mathrm{C},(b)$ salinity in psu, and $(c)$ zonal velocity in $\mathrm{cm} \mathrm{s}^{-1}$ along $142^{\circ} \mathrm{E}$. The zonal geostrophic velocity relative to 600 dbar calculated from the data in Figure $5 a$ and Figure $5 b$ appears in Figure $5 d$. Solid contours denote eastward flow.

during WEPOCS 02 (350 dbar), USPRC 03 (at $400 \mathrm{dbar}$ ), and USPRC 06 (at $400 \mathrm{dbar}$ ), but appeared more as a northward extension of the New Guinea Coastal Undercurrent. Never was a local maximum of westward flow observed under the Undercurrent as in the mean section at $165^{\circ} \mathrm{E}$. However, the direct measurements by Kort et al. [1966] along $140^{\circ} \mathrm{E}$ did document a well-defined Equatorial Intermediate Current with a maximum velocity of $40 \mathrm{~cm} \mathrm{~s}^{-1}$ at $500 \mathrm{~m}$. These data also gave a hint of a southern Subsurface Countercurrent, but with velocities less than $10 \mathrm{~cm} \mathrm{~s}^{-1}$. Detailed examination of the seven sections of direct velocity measurements about $142^{\circ} \mathrm{E}$ found no evidence of the southern Subsurface Countercurrent, suggesting this flow must have originated east of $142^{\circ} \mathrm{E}$ during our study period. The southern Subsurface Countercurrent was present at $155^{\circ} \mathrm{E}$ on a section in January 1986 [Tsuchiya et al., 1989].

As no direct velocity measurements are available at $137^{\circ} \mathrm{E}$, we estimated the zonal currents from the thermal wind relation. Use of the geostrophic relationship to compute the zonal component of the velocity at the equator has been widely used, since it was demonstrated that with sufficient averaging, good agreement can be obtained with directly measured currents (i.e., Hayes [1982], Lukas and Firing [1984], Delcroix et al. [1987]). However, the validity of this technique in the far western Pacific, where the zonal currents are not symmetric about the equator, was not clear. In support of the calculation at $137^{\circ} \mathrm{E}$, we also estimated geostrophic currents at our other two meridians and made comparisons to the directly measured velocity. We first referenced the geostrophic velocity to $1000 \mathrm{dbar}$, but there were some discrepancies with the mean sections of directly measured velocity. The main one was that currents at the equator had too strong an eastward component, with no evidence of the westward Equatorial Intermediate Current. Instead, a maximum of eastward velocity between $400 \mathrm{dbar}$ and $600 \mathrm{dbar}$ was obtained at the equator with westward currents at $400 \mathrm{dbar}$ about $1.5^{\circ} \mathrm{N}$ and $1.5^{\circ} \mathrm{S}$. So, we chose a $600-\mathrm{dbar}$ zero-velocity surface to reference the geostrophic velocities (Figure $3 d$ ). In this case, the geostrophic estimate of the Undercurrent core velocity is 61 $\mathrm{cm} \mathrm{s}^{-1}, 13 \mathrm{~cm} \mathrm{~s}^{-1}$ stronger that directly measured. The 600-dbar 
A
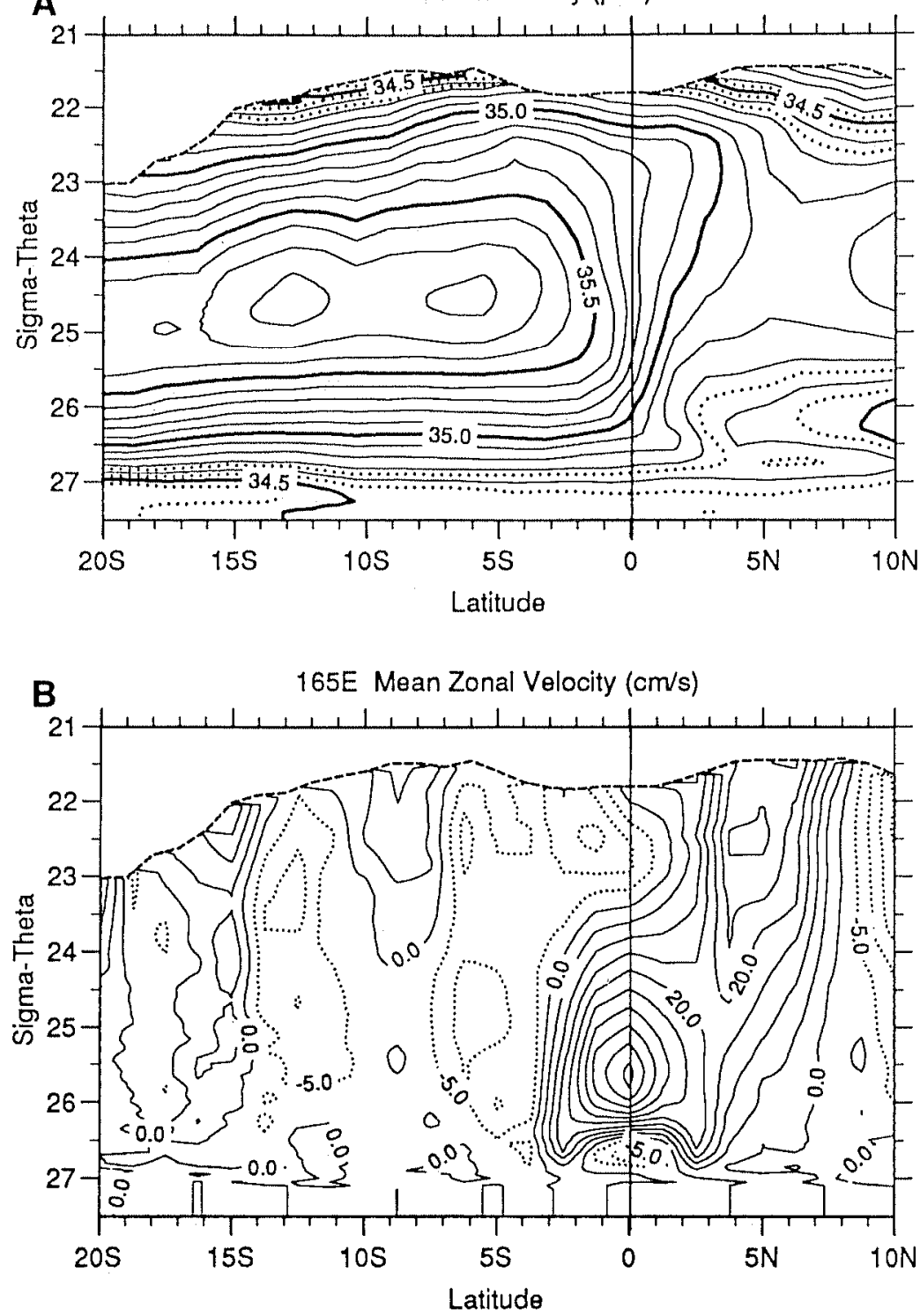
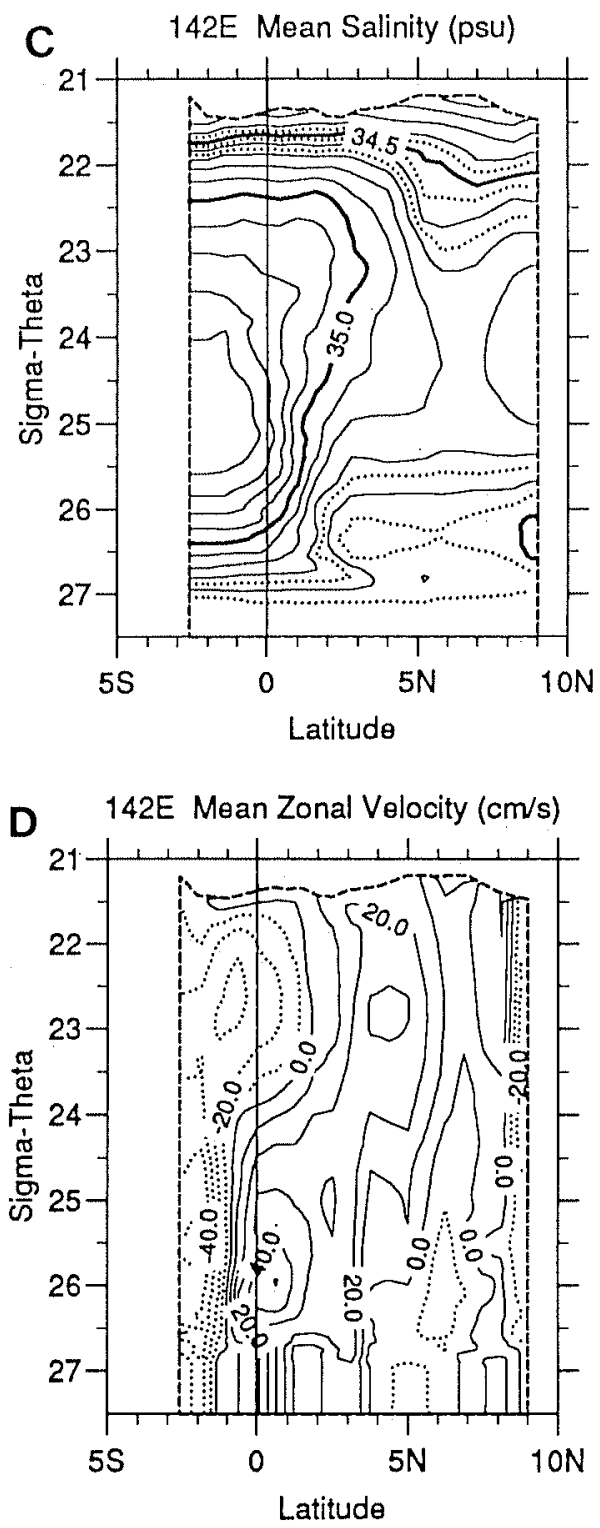

Fig. 6. Mean meridional sections with potential density anomaly as ordinate. (a) Salinity in psu and (b) zonal velocity in $\mathrm{cm} \mathrm{s}^{-1}$ along $165^{\circ} \mathrm{E}$. $(c)$ Salinity in psu and $(d)$ zonal velocity in $\mathrm{cm} \mathrm{s}^{-1}$ along $142^{\circ} \mathrm{E}$. Solid contours denote eastward relative flow.

reference yields a well-defined Intermediate Current which, quantitatively, compares quite well with the measurements. The measured velocities gave an averaged maximum speed of $15 \mathrm{~cm}$ $\mathrm{s}^{-1}$ at $0.5^{\circ} \mathrm{N}$ (13 $\mathrm{cm} \mathrm{s}^{-1}$ at the equator), the geostrophic velocity is maximum at $1.25^{\circ} \mathrm{S}: 16 \mathrm{~cm} \mathrm{~s}^{-1}\left(10 \mathrm{~cm} \mathrm{~s}^{-1}\right.$ at the equator).

Agreement between the directly measured and geostrophic currents relative to $600 \mathrm{dbar}$ at $165^{\circ} \mathrm{E}$ could reflect the preponderance of PCM measurements in the average that were also referenced to $600 \mathrm{~m}$ (cf. appendix). In contrast, all of the velocity measurements that make up the $142^{\circ} \mathrm{E}$ average section were made with an ADCP, and are thus absolute. Nevertheless, here also we found that the best reference for computing the geostrophic velocity close to the equator was $600 \mathrm{dbar}$ (Figure $5 d$ ). In general, the agreement between direct and geostrophic currents was poorer than at $165^{\circ} \mathrm{E}$; only eight sections were used to compute the mean density profile. Even so, the geostrophic calculation retrieves the location and strength of the main near equatorial currents. As mentioned previously, the $142^{\circ} \mathrm{E}$ average north of $5^{\circ} \mathrm{N}$ is suspect due to the small number of cruises that extended north of that latitude.

Qiu and Joyce [1992] previously reported geostrophic currents at $137^{\circ} \mathrm{E}$ north of $2^{\circ} \mathrm{N}$ employing a reference of $1000 \mathrm{dbar}$. Here we extend the computation to $1^{\circ} \mathrm{S}$ (Figure $4 c$ ), using a reference of $600 \mathrm{dbar}$ as motivated by the data at $142^{\circ} \mathrm{E}$. Quite interestingly, the velocity distribution exhibits an eastward subsurface current centered at $0.75^{\circ} \mathrm{N}$ between $100 \mathrm{dbar}$ and $300 \mathrm{dbar}$ (23.5 $\mathrm{cm} \mathrm{s}^{-1}$ at $190 \mathrm{dbar}$ ). This current also appeared when a reference of $1000 \mathrm{dbar}$ was chosen for the geostrophic calculation $\left(18 \mathrm{~cm} \mathrm{~s}^{-1}\right)$. We speculate that this eastward jet is the Equatorial Undercurrent. The weak core speed, in comparison to our sections farther east, suggests $137^{\circ} \mathrm{E}$ is near the westernmost extent of the Undercurrent. If so, curvature and zonal gradients of the flow associated with the retroflection of the Undercurrent probably limit the validity of the equatorial geostrophic relation. However, hints of the Equatorial Undercurrent had previously been found along $137^{\circ} \mathrm{E}$ by direct measurement in January 1967 . 
1968, 1970 during the first cruises of the Japanese program [Masuzawa, 1967; Masuzawa, 1968; Masuzawa et al., 1970]. Direct measurements of currents made during the Vitiaz cruise 38 in January-April 1966 also indicated the presence of the Equatorial Undercurrent at $137^{\circ} \mathrm{E}$ [Kort et al., 1966]. South of the equator, westward flow is deduced. By analogy to the $142^{\circ} \mathrm{E}$ section, we tentatively define this as the extension of the New Guinea Coastal Undercurrent. Like the Equatorial Undercurrent, this flow is much reduced at $137^{\circ} \mathrm{E}$ as compared with $142^{\circ} \mathrm{E}$. At $137^{\circ} \mathrm{E}$, weak eastward flow is obtained at the southernmost station pair on the section $\left(0.5^{\circ}-1^{\circ} \mathrm{S}\right)$. Based on the salinity distribution, we would argue this is spurious, as this flow direction sends the Southern Tropical Water core back towards its source. North of the equator, the most significant difference in the currents at $137^{\circ} \mathrm{E}$ versus the other meridians is the structure of the two Countercurrents. Here there is no velocity minimum between the North Equatorial Countercurrent and its subsurface counterpart (Figure $4 c$ ). What appears is a deep reaching eastward current, whose core shifts southward with increasing depth.

\subsection{Current Transport Estimates}

The main difficulty in estimating the transport of the various near-equatorial current is definitional: deciding where the boundaries are between the Subsurface Countercurrents and the Equatorial Undercurrent, and between the North Equatorial Countercurrent and northern Subsurface Countercurrent (Figure $3 c$ ). We have set the limits of these currents as follows: (1) the Equatorial Undercurrent is the eastward current in the thermocline between $2^{\circ} \mathrm{S}$ and $2^{\circ} \mathrm{N}$; (2) the southern Subsurface Countercurrent is the eastward flow between $2^{\circ} \mathrm{S}$ and $4.5^{\circ} \mathrm{S}$; (3) the limit between the two northern Countercurrents and the Undercurrent was set at the relative minimum of eastward velocity (dashed line on Figure $3 c$ ). In the latter case we did not follow Delcroix et al. [1987], who chose the surface $23.5 \mathrm{mg}$ $\mathrm{cm}^{-3}$ (corresponding roughly to the $25^{\circ} \mathrm{C}$ isotherm) as a lower limit for the Countercurrent. (4) The South Equatorial Current transport includes all westward flow between $15^{\circ} \mathrm{S}$ and $3^{\circ} \mathrm{N}$. We report separately the transport of the westward current between $20^{\circ} \mathrm{S}$ and $15^{\circ} \mathrm{S}$ (SEC 2 in Table 3). (5) The South Tropical Countercurrent has been defined as the eastward current south of $13^{\circ} \mathrm{S}$. Our estimates of the mean volume transport of these currents at $165^{\circ} \mathrm{E}$ appear in Table 3. Agreement between the directly measured and geostrophic transports is excellent, especially for the subsurface currents (differences are $2 \times 10^{6} \mathrm{~m}^{3} \mathrm{~s}^{-1}$ or less). Both direct and geostrophic figures give a northern Subsurface Countercurrent transport greater than the southern one, by an amount of $4 \times 10^{6} \mathrm{~m}^{3} \mathrm{~s}^{-1}(34 \%)$ in the case of the direct measurements and $5 \times 10^{6} \mathrm{~m}^{3} \mathrm{~s}^{-1}(43 \%)$ with the geostrophic estimation. The main transport discrepancy between directly measured and geostrophic transports at $165^{\circ} \mathrm{E}$ is for the South Equatorial Current; the measured transport is lower than the geostrophic by $13 \times 10^{6} \mathrm{~m}^{3} \mathrm{~s}^{-1}$. This difference comes principally from the large westward surface currents at the equator deduced geostrophically, but not directly measured, (Figure $3 d$ ). In addition, ageostrophic surface flows driven by wind are thought important in the western Pacific [McPhaden et al., 1990]. On the other hand, $\mathrm{ADCP}$ and profiler measurements are not reliable from the surface to $20 \mathrm{dbar}$ (see above).

Delcroix et al. [1987] reported transport estimates from the first six SURTROPAC cruises (a period in which no El Niño conditions were observed) (Table 3). They obtained larger transports than are given here for each of the investigated currents by $16-56 \%$. The smaller Equatorial Undercurrent value obtained here reflects the fact that during the 1986-1987 El Niño the Undercurrent decreased and even disappeared (it was replaced by westward flow during USPRC 03). Extended periods of reduced North Equatorial Countercurrent flow were also observed during this time [Delcroix et al., 1992].

Transport figures obtained from the $142^{\circ} \mathrm{E}$ mean section are quite comparable to those for $165^{\circ} \mathrm{E}$ (Table 4); the principal discrepancies are again definitional. For example, the $142^{\circ} \mathrm{E}$ direct velocity measurements did not extend as deep as at $165^{\circ} \mathrm{E}$. Additional eastward Equatorial Undercurrent transport is suggested from the geostrophic calculations below $300 \mathrm{dbar}$ (the limit of the ADCP data). Thus we find little zonal change in total Undercurrent transport between $142^{\circ}$ and $165^{\circ} \mathrm{E}$. What we term the South Equatorial Current in Table 4 is the westward current south of $1^{\circ} \mathrm{N}$; that is, it includes the New Guinea Coastal Undercurrent. This combined westward transport is essentially identical to our South Equatorial Current transport value for $165^{\circ} \mathrm{E}$. Recall however, the property distributions noted above argue against a straightforward link between these flows. We obtain a smaller North Equatorial Countercurrent transport at $142^{\circ} \mathrm{E}$ than $165^{\circ} \mathrm{E}$, in contrast with Toole et al. [1988], who found the Countercurrent transport decreased to the east. As not all of the sections used in the $142^{\circ} \mathrm{E}$ average spanned the full latitudinal extent of the Countercurrent, and the sections are relatively limited in number (at least in comparison with the $165^{\circ}$ and $137^{\circ} \mathrm{E}$ meridians) we are less confident in the $142^{\circ} \mathrm{E}$ Countercurrent transport figure.

TABLE 3. Mean Transport at $165^{\circ} \mathrm{E}$ in $10^{6} \mathrm{~m}^{3} \mathrm{~s}^{-1}$

\begin{tabular}{lcccc}
\hline & $\begin{array}{c}\text { Direct } \\
\text { Meastrement }\end{array}$ & $\begin{array}{c}\text { Geostrophy* } \\
\text { /600 dbar }\end{array}$ & $\begin{array}{c}\text { Geostrophy* } \\
\text { /1000 dbar }\end{array}$ & $\begin{array}{c}\text { Delcroix el al. } \\
{[1987]}\end{array}$ \\
\hline STCC & 6.6 & 2.7 & 2.3 & $?$ \\
SEC 2 & -2.9 & -1.3 & -4.9 & $?$ \\
SECC & 3.7 & 3.6 & 3.8 & $?$ \\
SEC & -24.8 & -37.7 & -41.7 & -38.8 \\
SSCC & 7.6 & 6.5 & 10.6 & 8.8 \\
EUC & 15.3 & 17.3 & 26.1 & 19.7 \\
EIC & -4.5 & -4.9 & -2.6 & -7.0 \\
NSCC & 11.7 & 11.4 & 11.1 & 14.8 \\
NECC & 20.4 & 19.6 & 18.9 & 27.4 \\
\hline
\end{tabular}

STCC, South Tropical Countercurrent; SEC, South Equatorial Current; SECC, South Equatorial Countercurrent; SSCC, Southern Subsurlace Countercurrent; EUC, Equatorial Undereurrent; EIC, Equatorial Intermediate Current; NSCC, Northern Subsurface Countercurrent; NECC, North Equatorial Countercurrent.

$*$ Geostrophic velocity computed every hall degree ol latitude between $1^{\circ}$ and $3^{\circ}$. 
TABLE 4. Mean Transport it $142^{\circ} \mathrm{E}$ in $10^{6} \mathrm{~m}^{3} \mathrm{~s}^{-1}$

\begin{tabular}{lcc}
\hline & $\begin{array}{c}\text { Direct } \\
\text { Measurement }\end{array}$ & $\begin{array}{c}\text { Geostrophy } \\
1600 \text { dbar }\end{array}$ \\
\hline SEC & -23.8 & -31.0 \\
EUC & $13.8^{+}$ & 26.3 \\
NSCC & 10.7 & 9.0 \\
NECC & 16.9 & 27.6 \\
\hline
\end{tabular}

SEC, South Equatorial Current; EUC, Equatorial Undercurrent; NSCC, Northern Subsurface Countercurrent; NECC, North Equatorial Countercurrent.

* The transports are computed to $400 \mathrm{dbar}$.

t The transport is only computed to $300 \mathrm{dbar}$. The geostrophic transport for the EUC below 300 dbar is $6.510^{6} \mathrm{~m}^{3} \mathrm{~s}^{-1}$.

As expected from the velocity section, the Equatorial Undercurrent transport is much reduced at $137^{\circ} \mathrm{E}\left(4.1 \times 10^{6} \mathrm{~m}^{3}\right.$ $\mathrm{s}^{-1}$ with a reference at $600 \mathrm{dbar}, 1.9 \times 10^{6} \mathrm{~m}^{3} \mathrm{~s}^{-1}$ with a reference at $1000 \mathrm{dbar}$ ) (Tables 5 , and 6)). Lacking a means to distinguish the North Equatorial Countercurrent and northern Subsurface Countercurrent at $137^{\circ} \mathrm{E}$, we report the combined transport (43.1 $\times 10^{6} \mathrm{~m}^{3} \mathrm{~s}^{-1}$ with a reference of $600 \mathrm{dbar}, 48.2 \times 10^{6} \mathrm{~m}^{3} \mathrm{~s}^{-1}$ referenced to $1000 \mathrm{dbar}$ ). At $165^{\circ} \mathrm{E}$, the sum of the North Equatorial Countercurrent and northern Subsurface Countercurrent transport is $32.1 \times 10^{6} \mathrm{~m}^{3} \mathrm{~s}^{-1}$ (geostrophically relative to $600 \mathrm{dbar}$ : $31.0 \times 10^{6} \mathrm{~m}^{3} \mathrm{~s}^{-1}$ ). This study confirms a downstream decrease in Countercurrent transport in the western Pacific. Qiu and Joyce [1992] obtained a somewhat larger average Countercurrent transport of $51.5 \times 10^{6} \mathrm{~m}^{3} \mathrm{~s}^{-1}$ at $137^{\circ} \mathrm{E}$ (s.d. 17.5 $\times 10^{6} \mathrm{~m}^{3} \mathrm{~s}^{-1}$ ) for the Japan Meteorological Agency cruises between January 1967 and July 1988. The difference with our estimation comes mainly from the fact that Qiu and Joyce estimated the Countercurrent transport for each cruise and then worked out the average, whereas we estimated the transport from our mean section of velocity. In the former, the seasonal meridional displacement and areal expansion of the Countercurrent resulted in integrations over different latitudinal bounds. The different averaging period employed by our studies does not appear to cause the difference. Restricting Qiu and Joyce's Countercurrent average to the cruises between 1972 and 1985 that are examined here yields a figure of $52 \times 10^{6} \mathrm{~m}^{3} \mathrm{~s}^{-1}$ (s.d. $18.4 \times 10^{6} \mathrm{~m}^{3} \mathrm{~s}^{-1}$ ), essentially identical to what they reported.

On the basis of one cruise (WEPOCS 2), Tsuchiya et al. [1989] estimated that of the $10 \times 10^{6} \mathrm{~m}^{3} \mathrm{~s}^{-1}$ transport in the Equatorial Undercurrent at $143^{\circ} \mathrm{E}, 7 \times 10^{6} \mathrm{~m}^{3} \mathrm{~s}^{-1}$ comes from the New Guinea CoastaI Undercurrent. In a further attempt to quantify this subsurface circulation and document relationships between the currents, the volume transport stream function was estimated from our mean velocity sections. We focus on the po-

TABLE 5. Geostrophic Transport at $137^{\circ} \mathrm{E}$ in $10^{6} \mathrm{~m}^{3} \mathrm{~s}^{-1}$, Reference 600 dbar

\begin{tabular}{lccc}
\hline & Mean* $^{*}$ & July $^{+}$ & January $^{++}$ \\
\hline EUC & 4.1 & & 12.4 \\
NECC & 43.1 & 52.5 & 34.9 \\
\hline
\end{tabular}

EUC, Eqquatorial Undercurrent; NECC, North Equatorial Countercurrent.

* EUC transport computed between $0^{\circ}$ and $1.5^{\circ} \mathrm{N}$, NECC transport computed between $2^{\circ} \mathrm{N}$ and $8^{\circ} \mathrm{N}$.

+ No estimation of the EUC transport has been made for July (see text). NECC transport computed between $1.5^{\circ} \mathrm{N}$ and $8^{\circ} \mathrm{N}$.

++ EUC transport computed between $0^{\circ}$ and $3^{\circ} \mathrm{N}$, NECC transport computed between $3^{\circ} \mathrm{N}$ and $8^{\circ} \mathrm{N}$.
TABILE 6. Geostrophic Transport at $137^{\circ} \mathrm{E}$ in $10^{6} \mathrm{~m}^{3} \mathrm{~s}^{-1}$, Reference 1000 dbar

\begin{tabular}{lrcc}
\hline & Mean* $^{*}$ & July $^{+}$ & January $^{++}$ \\
\hline EUC & 1.9 & & 5.7 \\
NECC & 48.2 & 56.3 & 44.8 \\
\hline
\end{tabular}

EUC, Equatorial Undercurrent; NECC, North Equatorial Countercurrent.

* EUC transport computed between $0^{\circ}$ and $1.5^{\circ} \mathrm{N}$, NECC transport computed between $2^{\circ} \mathrm{N}$ and $8^{\circ} \mathrm{N}$.

+ No estimation of the EUC transport has been made for July (see text). NECC transport computed between $1.5^{\circ} \mathrm{N}$ and $8^{\circ} \mathrm{N}$.

++ EUC transport computed between $0^{\circ}$ and $3^{\circ} \mathrm{N}$, NECC transport computed between $3^{\circ} \mathrm{N}$ and $8^{\circ} \mathrm{N}$.

tential density anomaly interval between 23.5 and $26.4 \mathrm{mg} \mathrm{cm}^{-3}$. These surfaces encompass the major flux of the Equatorial Undercurrent (Figure 6). Running integrations of the velocity fields were made starting at the southern end of each section (Figure 7). The zero for these curves is thus arbitrary. It is perhaps fortuitous then that the stream function for $165^{\circ} \mathrm{E}$ is zero at $15^{\circ} \mathrm{S}$, just the latitude where the Sverdrup transport is zero [Kessler and Taft, 1987]. Yet with this reference for the $165^{\circ} \mathrm{E}$ stream function, the westward transport south of $5^{\circ} \mathrm{S}$ is entirely compensated by the southern Subsurface Countercurrent and Equatorial Undercurrent flow south of the equator; the stream function goes through zero right at the equator $\left(0.25^{\circ} \mathrm{N}\right.$, as there is a velocity profile every $0.5^{\circ}$ of latitude between $2.5^{\circ} \mathrm{S}$ and $2.5^{\circ} \mathrm{N}$ ). The curve continues to increase northward across the rest of the Undercurrent and northern Countercurrents to $7^{\circ} \mathrm{N}$, where the North Equatorial Current begins.

The character of the stream function is similar at $142^{\circ} \mathrm{E}$, but compressed meridionally. In this case, the stream function regains zero north of the equator, at $1.75^{\circ} \mathrm{N}$. Westward transport in the New Guinea Coastal Undercurrent is compensated by the Equatorial Undercurrent flow south of $1.75^{\circ} \mathrm{N}$. As before, the stream function continues to increase farther north. Table 7 displays the volume transport and transport weighted mean salinity for different ranges of latitude for this density interval. The New Guinea Coastal Undercurrent integrates to $-10.4 \times 10^{6} \mathrm{~m}^{3} \mathrm{~s}^{-1}$ with a mean salinity of 35.340 . The transport between $0.75^{\circ} \mathrm{S}$ and $1.75^{\circ} \mathrm{N}$ is eastward at $10.0 \times 10^{6} \mathrm{~m}^{3} \mathrm{~s}^{-1}$ with a mean salinity of 35.066. Assuming the stream function zero is correct, these figures indicate significant mixing of the southern Tropical Water with lower salinity waters takes place during the Coastal Undercurrent retroflection. At $165^{\circ} \mathrm{E}$, we chose the latitude of the South Tropical Countercurrent as a southern limit to compute the South Equatorial Current transport in this density interval. Between $14.5^{\circ} \mathrm{S}$ and $3.5^{\circ} \mathrm{S}$ the velocity sums to $-10.9 \times 10^{6}$ $\mathrm{m}^{3} \mathrm{~s}^{-1}$ at an average salinity of 35.558 . Although this volume transport is basically the same as that of the New Guinea Coastal Undercurrent, the South Equatorial Current waters moving west at $165^{\circ} \mathrm{E}$ are far saltier than those of the Coastal Undercurrent at $142^{\circ} \mathrm{E}$. This provides additional evidence that these two flows are not simply connected. At $165^{\circ} \mathrm{E}$, eastward volume transport to compensate the South Equatorial Current flow is obtained between $3.5^{\circ} \mathrm{S}$ and $0.25^{\circ} \mathrm{N}\left(10.3 \times 10^{6} \mathrm{~m}^{3} \mathrm{~s}^{-1}\right.$ having mean salinity of 35.233 ). The eastward increase of Undercurrent salinity was a robust feature of these data, quite independent of the spatial limits of integration employed, implying that the Undercurrent entrains salty southern Tropical Water as it flows east. We find about twice as much eastward transport in this density interval north of the transport strean function zero at $165^{\circ} \mathrm{E}$ than $142^{\circ} \mathrm{E}$ (Table 7). This is not a robust result, 
$165 \cdot E$ - Layer: $23.5-26.4$ Integrated Transport from 20.5

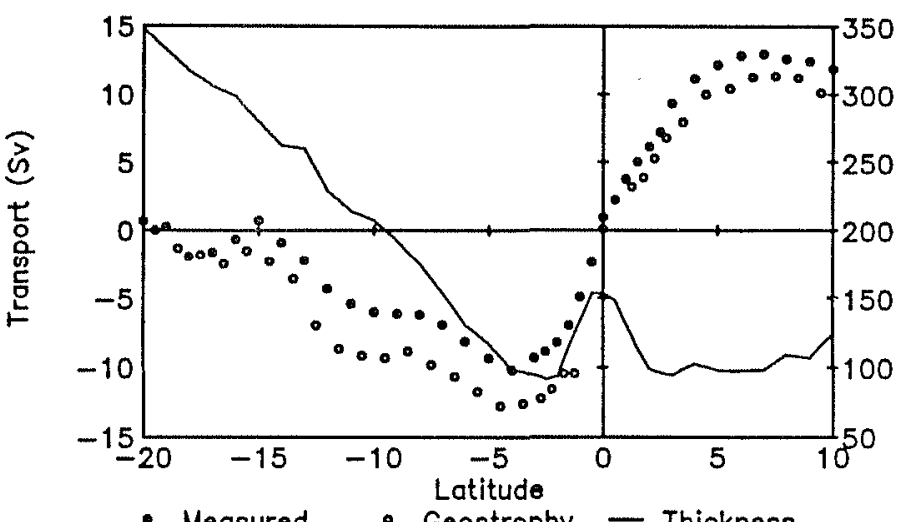

B $\quad 142 \cdot E$ - Layer: 23.5 - 26.4 Integrated Transport from $2.6 \cdot \mathrm{S}$

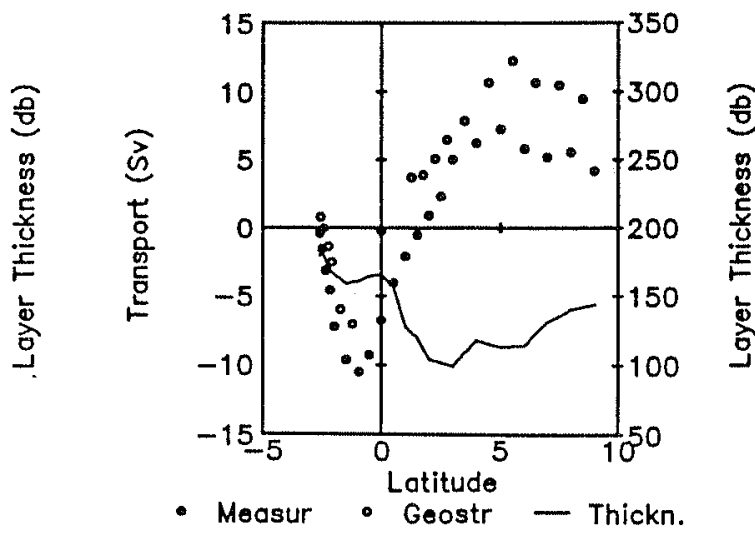

Fig. 7. Mean zonal transport stream function in $10^{6} \mathrm{~m}^{3} \mathrm{~s}^{-1}$ between the potential density anomaly surfaces 23.5 and $26.4 \mathrm{mg} \mathrm{cm}$. (a) Integrated northward from $20^{\circ} \mathrm{S}$ along $165^{\circ} \mathrm{E}$. (b) Integrated northward from $2.6^{\circ} \mathrm{S}$ along $142^{\circ} \mathrm{E}$. Solid circles, direct velocity measurements; open circles, geostrophic transport relative to $600 \mathrm{dbar}$; solid line, thickness in decibars of the layer $23.5-26.4 \mathrm{mg}$ $\mathrm{cm}^{-3}$.

as we suspect the average fields north of $5^{\circ} \mathrm{N}$ at $142^{\circ} \mathrm{E}$, based on a limited number of cruises, could be biased relative to the $165^{\circ} \mathrm{E}$ section.

More striking is the fact that the maximum Equatorial Undercurrent velocity is found on deeper density surfaces at $142^{\circ} \mathrm{E}\left(26.1 \mathrm{mg} \mathrm{cm}^{-3}\right)$ than at $165^{\circ} \mathrm{E}\left(25.7 \mathrm{mg} \mathrm{cm}^{-3}\right)$ (Figure 6). To check that the density difference was not an artifact of the different sampling at the two longitudes, we constructed a mean section at $165^{\circ} \mathrm{E}$ by using the same number of cruises, and close in time, to those used to build the mean at $142^{\circ} \mathrm{E}$. Some details in the velocity section varied as compared to that in Figure 3 (the transport of the Undercurrent was $13.6 \times 10^{6} \mathrm{~m}^{3} \mathrm{~s}^{-1}$ instead of $15.3 \times 10^{6} \mathrm{~m}^{3} \mathrm{~s}^{-1}$ ), however the density of the Equatorial Undercurrent core was the same as in the 27 -cruise average, around $25.7 \mathrm{mg} \mathrm{cm}^{-3}$. However, a Student test indicates that the velocities in the depth range of the Equatorial Undercurrent between the two longitudes are not different at the 0.05 significance level.

\subsection{Potential Vorticity}

Potential vorticity has recently been used to study the ocean circulation [e.g., Keffer, 1985; Talley, 1988], exploiting its character as a dynamical tracer. In this study, potential vorticity $(Q)$ has been calculated as

$$
Q=\left(f-u_{y}\right) E
$$

TABLE 7. Transport in $10^{6} \mathrm{~m}^{3} \mathrm{~s}^{-1}$ and Weighted Salinity Transport in psu Between the Surface Sigma-Theta 23.5 and $26.4 \mathrm{mg} \mathrm{cm}^{-3}$

$165^{\circ} \mathrm{E}$

\begin{tabular}{lcccc}
\hline Latitude & $14.5^{\circ} \mathrm{S}-3.5^{\circ} \mathrm{S}$ & $3.5^{\circ} \mathrm{S}-.25^{\circ} \mathrm{N}$ & $.25^{\circ} \mathrm{N}-7.5^{\circ} \mathrm{N}$ & $3.5^{\circ} \mathrm{S}-7.5^{\circ} \mathrm{N}$ \\
\hline Transport & -10.89 & 10.29 & 12.35 & 22.64 \\
Salinity & 35.558 & 35.233 & 34.868 & 35.034 \\
\hline
\end{tabular}

$142^{\circ} \mathrm{E}$

\begin{tabular}{lcccc}
\hline Latitude & $2.6^{\circ} \mathrm{S}-.75^{\circ} \mathrm{S}$ & $.75^{\circ} \mathrm{S}-1.75^{\circ} \mathrm{N}$ & $1.75^{\circ} \mathrm{N}-5.5^{\circ} \mathrm{N}$ & $.75^{\circ} \mathrm{S}-5.5^{\circ} \mathrm{N}$ \\
\hline Transport & -10.44 & 9.95 & 6.99 & 16.94 \\
Silinity & 35.340 & 35.066 & 34.789 & 34.952 \\
\hline
\end{tabular}

where $f$ is the Coriolis parameter and $u_{y}$ is the meridional gradient of the zonal component of velocity. The stability parameter, $E=1 / \rho . \partial \rho / \partial z$, was computed following Millard et al. [1990].

Generally, the relative vorticity is not included in the potential vorticity term as it is not readily accessible for the world ocean [Keffer, 1985; Talley 1988] and is generally negligible compared to the planetary vorticity except in regions of strong currents. As relative vorticity might be important in the Equatorial Undercurrent, we included it in the computation. The meridional shear was computed on isopycnal surfaces (so-called natural coordinates) with a centered finite difference scheme over $2^{\circ}$ of latitude off $2.5^{\circ} \mathrm{N}-2.5^{\circ} \mathrm{S}$ and over $1^{\circ}$ of latitude in between. Meridional sections of potential vorticity on density surfaces along $165^{\circ} \mathrm{E}$ and $142^{\circ} \mathrm{E}$ are presented as Figure 8. Similar pictures have previously been reported by Talley [1988]; the present ones differ on several points: (1) fine- resolution CTD data are used as opposed to standard level hydrographic observations, (2) relative vorticity has been included $\left(-u_{y}\right),(3)$ the section extends to $20^{\circ} \mathrm{S}$. (Talley's computation stopped at the equator).

The potential vorticity displays a maximum at the northern edge of the study domain, within the 22.5 and $23.5 \mathrm{mg} \mathrm{cm}^{-3}$ potential density anomaly surfaces (around $100 \mathrm{dbar}$ ) (Figure $8 a$ ). It is located just beyond the northern boundary of the North Equatorial Countercurrent and is a consequence of the extremely sharp thermocline found at that latitude (Figure $3 b$ ). This maximum is stronger ( $>14 \times 10^{-12} \mathrm{~cm}^{-1} \mathrm{~s}^{-1}$ ) than that shown in Talley [1988] $\left(10 \times 10^{-12} \mathrm{~cm}^{-1} \mathrm{~s}^{-1}\right.$ at $\left.165^{\circ} \mathrm{E}\right)$, probably because we used CTD data averaged on isopycnals. Talley showed that this potential vorticity feature, extending zonally across the entire Pacific, is coincident with a region of positive mean Ekman vertical velocity just north of the Intertropical Convergence Zone. We find a counterpart to this feature in the southern hemisphere south of about $15^{\circ} \mathrm{S}$ (values above $9 \times 10^{-12} \mathrm{~cm}^{-1} \mathrm{~s}^{-1}$ ). In this case, the high potential vorticity may be associated with the wind stress curl of the South Pacific Convergence Zone. Buoyancy forcing (specifically rainfall) could also be playing a role; the large potential vorticity values derive in part from the salinity gradient between the mixed layer and the Tropical Water. At deeper levels (sigma theta around $25.5 \mathrm{mg} \mathrm{cm}^{-3}$ ), poleward of about $5^{\circ}$ latitude in both hemispheres, potential vorticity is nearly constant on isopycnal surfaces. In the ther- 

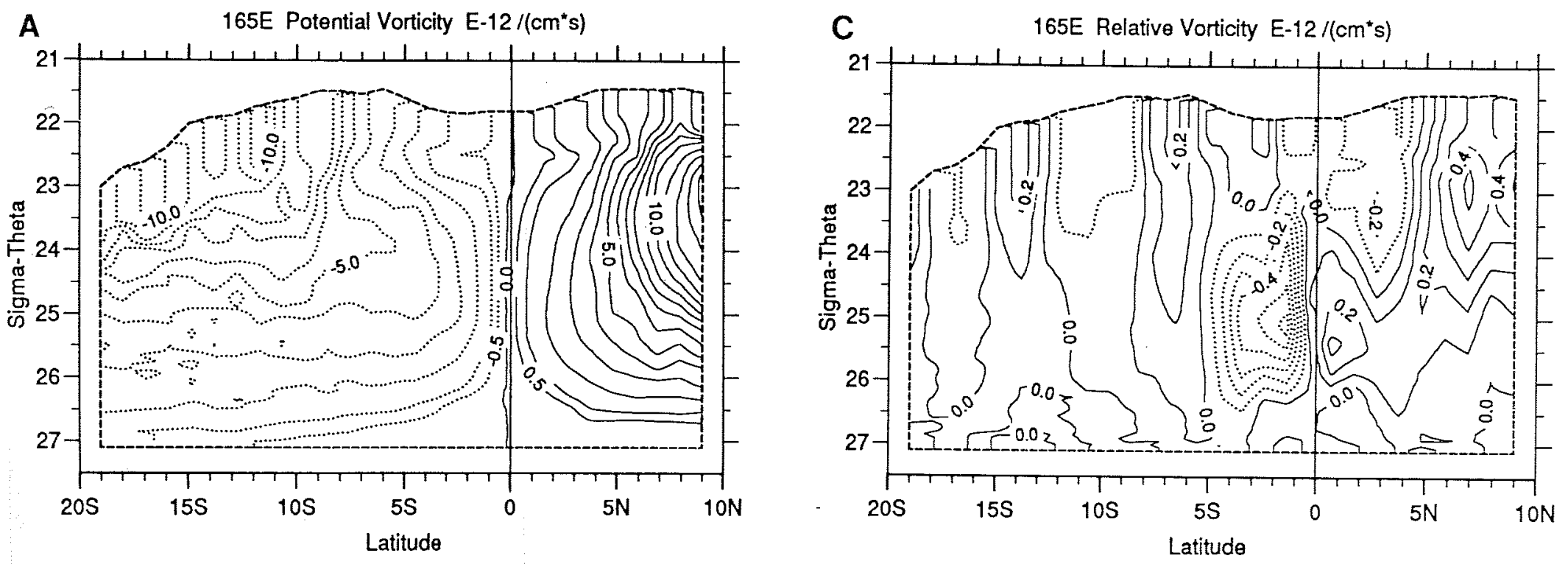

B $142 E$ Potential Vorticity E-12/(cm*s)
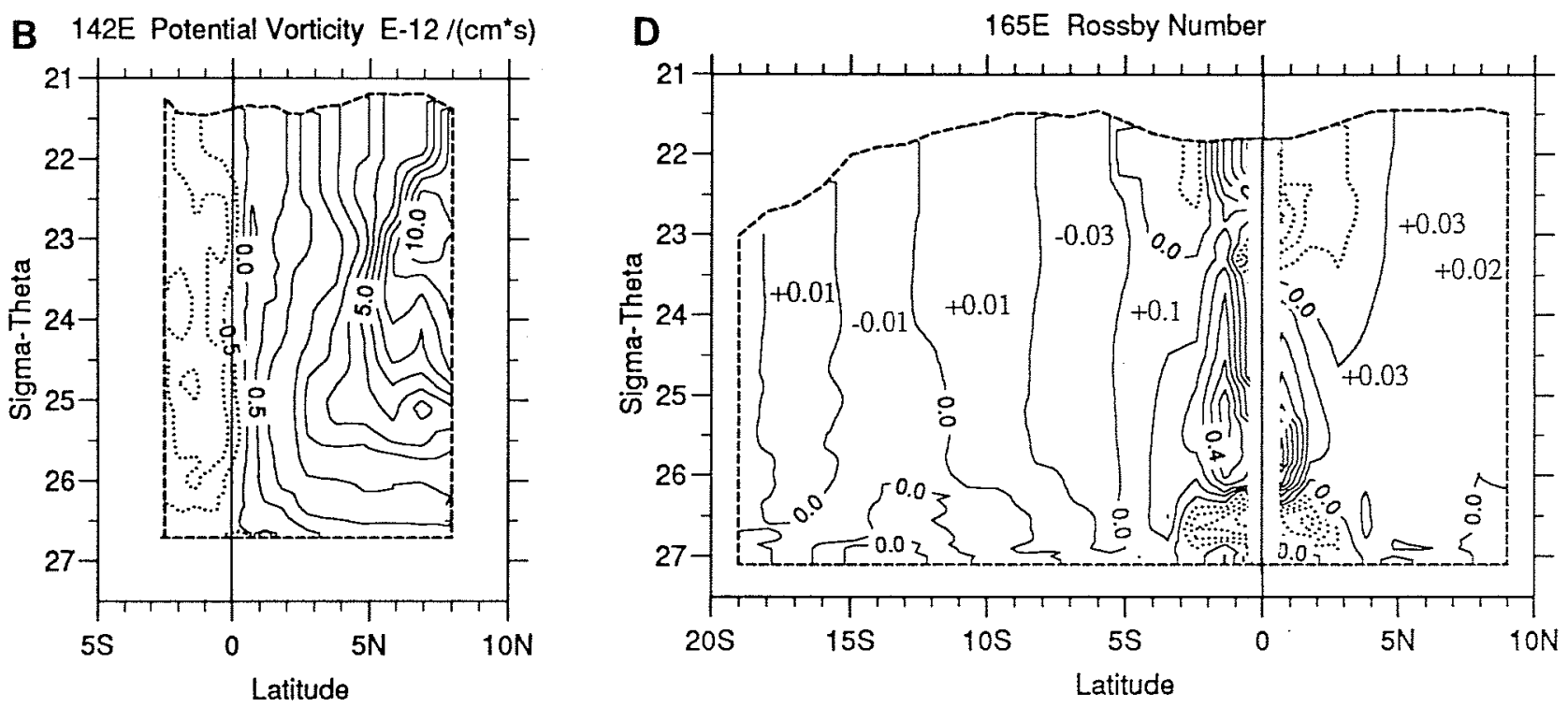

Fig. 8. Mean sections with potential density anomaly as ordinate of potential vorticity $((f-U) E)$ in $10^{-12} \mathrm{~cm}^{-1} \mathrm{~s}^{-1}$. (a) Along $165^{\circ} \mathrm{E}$ and (b) along $142^{\circ} \mathrm{E}$. (c) Mean section of relative vorticity $\left(-u_{y} E\right)$ in $10^{-12} \mathrm{~cm}^{-1} \mathrm{~s}^{-1}$ along $165^{\circ} \mathrm{E}$. (d) Mean section of Rossby number $\left(-u_{y} f\right)$ along $165^{\circ} \mathrm{E}$. Overlaid numbers indicate the order of magnitude of the Rossby number. 
mocline within two degrees of the equator, potential vorticity changes rapidly with latitude. Here the relative vorticity is significant in this region of strong currents (Figure $8 c$ ). The Rossby number is largest (about 0.5 ) at the level of the Equatorial Undercurrent ( $25.5 \mathrm{mg} \mathrm{cm}^{-3}$ density anomaly surface) and the Equatorial Intermediate Current $\left(26.7 \mathrm{mg} \mathrm{cm}^{-3}\right.$ surface) (Figure $8 d$ ). (Below we discuss the distributions of potential vorticity, salinity, and zonal component of velocity on these surfaces.) At the depths of the Equatorial Undercurrent, the relative vorticity acts to sharpen the potential vorticity front at the equator. By contrast, the shear term below the thermocline at the depths of the Equatorial Intermediate Current and Subsurface Countercurrents has the opposite sense, and acts to reduce the meridional potential vorticity gradients between $3^{\circ} \mathrm{N}$ and $3^{\circ} \mathrm{S}$, the latitudes of maximum subsurface countercurrent velocity.

The distribution of potential vorticity along $142^{\circ} \mathrm{E}$ is similar to that at $165^{\circ} \mathrm{E}$ (Figure $8 b$ ). There is a maximum of potential vorticity $\left(>10 \times 10^{-12} \mathrm{~cm}^{-1} \mathrm{~s}^{-1}\right)$ on the $23 \mathrm{mg} \mathrm{cm}^{-3}$ surface around $8^{\circ} \mathrm{N}$. Again this maximum is stronger than the one shown by Talley [1988] at $140^{\circ} \mathrm{E}-10^{\circ} \mathrm{N}\left(9 \times 10^{-12} \mathrm{~cm}^{-1} \mathrm{~s}^{-1}\right)$, although the present section does not reach $10^{\circ} \mathrm{N}$. The original feature at this longitude is the displacement from the equator toward $0.5^{\circ} \mathrm{N}$ of the zero line of potential vorticity. This shift is due to the relative vorticity, which is dominant close to the equator, arising from the strong meridional gradient of the zonal component of velocity between the Equatorial Undercurrent and the NewGuinea Coastal Undercurrent.

A notable feature of these mean $Q$ distributions (more apparent below where $Q$ on individual density surfaces is examined) is the monotonic northward increase of values along density surfaces. The well-known necessary condition for linear instability of $Q$ changing sign with latitude is thus not met by the mean flow field in the western equatorial Pacific. (In contrast, meridional shears of the central and eastern Pacific currents are thought sufficient to support instability waves [Cox; 1980; Philander et al., 1985; Lukas, 1987; Brady, 19901.) However, moored velocity measurements at the equator on $165^{\circ} \mathrm{E}$ do contain high-frequency fluctuations with characteristics akin to the waves seen in the eastern Pacific [e.g., McPhaden et al., 1990]. The $Q$ distributions imply that these must be remotely forced, or locally generated by wind stress (McPhaden et al. [1990] find significant coherence with the local wind near 10-day periods). There are two caveats that should be noted. First, the seasonal modulation of the western Pacific current shears might result in periods when $Q$, changes sign and unstable growth is possible (as occurs in the eastern Pacific). Second, at finite amplitude, energy can still be extracted from the mean flow even though the fluctuations have modified the background state so that the instability condition is no longer met. A detailed analysis of the energy budget, as was developed by Brady [1990] for the eastern Pacific, would help clarify the situation in the west.

3.4.1. The $22.5 \mathrm{mg} \mathrm{cm}^{-3}$ surface (Figure 9). This isopycnal lies close to the sea surface, just above the South Tropical Water at about $90 \mathrm{dbar}$ at $165^{\circ} \mathrm{E}-0^{\circ}$ (Figures $3 \mathrm{c}$ and 6). The principal current on that surface at each longitude is the North Equatorial Countercurrent, with a maximum velocity of $55 \mathrm{~cm} \mathrm{~s}^{-1}$ at $5^{\circ} \mathrm{N}$ $137^{\circ} \mathrm{E}, 29 \mathrm{~cm} \mathrm{~s}^{-1}$ at $5^{\circ} \mathrm{N}-141^{\circ} \mathrm{E}$, and $32 \mathrm{~cm} \mathrm{~s}^{-1}$ at $5^{\circ} \mathrm{N}-165^{\circ} \mathrm{E}$. This maximum of eastward velocity is associated with a maximum in the meridional gradient of salinity (Figures $9 b, 9 d, 9 e$ ). At each longitude the salinity is minimum at the northern edge of the North Equatorial Countercurrent and increases northward in the North Equatorial Current. Poleward of $10^{\circ} \mathrm{N}$, the salinity continues to increase to reach a maximum of 35.1 around $16^{\circ} \mathrm{N}$ [Toole et al., 1988; Qiu and Joyce, 1992]. This is the maximum of the Northern Tropical Water. South of the North Equatorial Countercurrent, at $137^{\circ} \mathrm{E}$ and $141^{\circ} \mathrm{E}$, the salinity is homogenized; at $165^{\circ} \mathrm{E}$, salinity increases southward to $5^{\circ} \mathrm{S}$ but with an inflection in the gradient just north of the equator. At that longitude, the decrease of salinity north of $5^{\circ} \mathrm{N}$ and south of $5^{\circ} \mathrm{S}$ reflects the influence of the precipitation linked to the southern and northern Intertropical Convergence Zones. Potential vorticity at $165^{\circ} \mathrm{E}$ (Figure $9 a$ ) on this surface displays a strong meridional gradient from $4^{\circ} \mathrm{N}$ to $9^{\circ} \mathrm{N}$ in the North Equatorial Countercurrent. Potential vorticity is more or less flat in the westward South Equatorial Current between $4^{\circ} \mathrm{N}$ and $4^{\circ} \mathrm{S}$, and increases again in the South Equatorial Countercurrent. At $142^{\circ} \mathrm{E}$ (Figure $9 \mathrm{c}$ ) the pattern of potential vorticity is similar with a maximum at $8^{\circ} \mathrm{N}$ that decreases in the North Equatorial Countercurrent toward $2^{\circ} \mathrm{N}$ and is more or less homogenized in the westward current south of $2^{\circ} \mathrm{N}$.

3.4.2. The $25.5 \mathrm{mg} \mathrm{cm}^{-3}$ surface (Figure 10). As noted above, this density falls in the core of the Equatorial Undercurrent at $165^{\circ} \mathrm{E}\left(190 \mathrm{dbar}\right.$ at $\left.0^{\circ} \mathrm{N}\right)$, just below the Tropical Water salinity maximum (Figures $3 c$ and 6 ). It is slightly above the Undercurrent velocity maximum at $142^{\circ} \mathrm{E}$. On this surface the Equatorial Undercurrent is readily apparent at $165^{\circ} \mathrm{E}\left(46 \mathrm{~cm} \mathrm{~s}^{-1}\right.$ at $\left.0^{\circ}-0.5^{\circ} \mathrm{S}\right)$, and $142^{\circ} \mathrm{E}\left(41 \mathrm{~cm} \mathrm{~s}^{-1}\right.$ at $\left.0.5^{\circ} \mathrm{N}\right)$. In contrast the North Equatorial Countercurrent is not associated with a velocity extremum at these longitudes. There are two maxima of eastward geostrophic current at $137^{\circ} \mathrm{E}$, the North Equatorial Countercurrent at $3.5^{\circ} \mathrm{N}\left(35 \mathrm{~cm} \mathrm{~s}^{-1}\right)$ and what could be considered the beginning of the Equatorial Undercurrent at $1^{\circ} \mathrm{N}\left(17 \mathrm{~cm} \mathrm{~s}^{-1}\right)$. The most striking feature in the property distributions with latitude are the gradients about the equator. The latitude of maximum meridional salinity gradient shifts south with distance east; it falls about $2^{\circ} \mathrm{N}-4^{\circ} \mathrm{N}$ at $137^{\circ} \mathrm{E}, 0^{\circ}-2.5^{\circ} \mathrm{N}$ at $142^{\circ} \mathrm{E}$ and $1^{\circ} \mathrm{S}-2^{\circ} \mathrm{N}$ at $165^{\circ} \mathrm{E}$ (Figure $10 b, 10 d, 10 e$ ). This displacement parallels the core of the Equatorial Undercurrent which is centered north of the equator at $142^{\circ} \mathrm{E}$ but is roughly symmetric about $0^{\circ}$ at $165^{\circ} \mathrm{E}$. This structure is also apparent in the potential vorticity distributions at $142^{\circ} \mathrm{E}$ and $165^{\circ} \mathrm{E}$ (Figures $10 a$ and $10 \mathrm{c}$ ). Poleward of the gradient region, salinity on this isopycnal is nearly constant. Potential vorticity south of $4^{\circ} \mathrm{S}$ is also quite uniform, but north of $4^{\circ} \mathrm{S}$ it increases nearly monotonically to the northern limit of this study (Figure 10a). Thus, fluid parcels appear relatively free to move meridionally poleward of $4^{\circ} \mathrm{S}$ in the southern hemisphere at these depths; the potential vorticity places a strong constraint on meridional flow north of the equator. The uniformity of $Q$ south of $4^{\circ} \mathrm{S}$ reflects a compensation for the latitudinal change of $f$ by a thinning of the pycnocline (increase of $E$ ) towards the equator.

3.4.3. The $26.7 \mathrm{mg} \mathrm{cm}^{-3}$ surface (Figure 11). At $165^{\circ} \mathrm{E}$, this surface crosses the core of the southern Subsurface Countercurrent $\left(20 \mathrm{~cm} \mathrm{~s}^{-1}\right.$ at $\left.3^{\circ} \mathrm{S}\right)$, the Equatorial Intermediate Current $\left(-15 \mathrm{~cm} \mathrm{~s}^{-1}\right.$ at $\left.0.5^{\circ} \mathrm{N}\right)$, and the northern Subsurface Countercurrent $\left(26 \mathrm{~cm} \mathrm{~s}^{-1}\right.$ at $3^{\circ} \mathrm{N}$ ) (Figures $3 c$ and 6 ). Of these, only the northern Subsurface Countercurrent $\left(26 \mathrm{~cm} \mathrm{~s}^{-1}\right.$ at $\left.3^{\circ} \mathrm{N}\right)$ is apparent at $142^{\circ} \mathrm{E}$. The other major current on this isopycnal at $142^{\circ} \mathrm{E}$ is the New Guinea Coastal Undercurrent $\left(-42 \mathrm{~cm} \mathrm{~s}^{-1}\right.$ at $2.17^{\circ} \mathrm{S}$ ). The geostrophic flow deduced at $137^{\circ} \mathrm{E}$ has a fairly broad eastward jet north of the equator $\left(16 \mathrm{~cm} \mathrm{~s}^{-1}\right.$ at $2.5^{\circ} \mathrm{N}$ ), possibly the northern Subsurface Countercurrent, with a hint of westward flow at the equator. There are several interesting features on these plots. In contrast to the $25.5 \mathrm{mg} \mathrm{cm}^{-3}$ density 
A

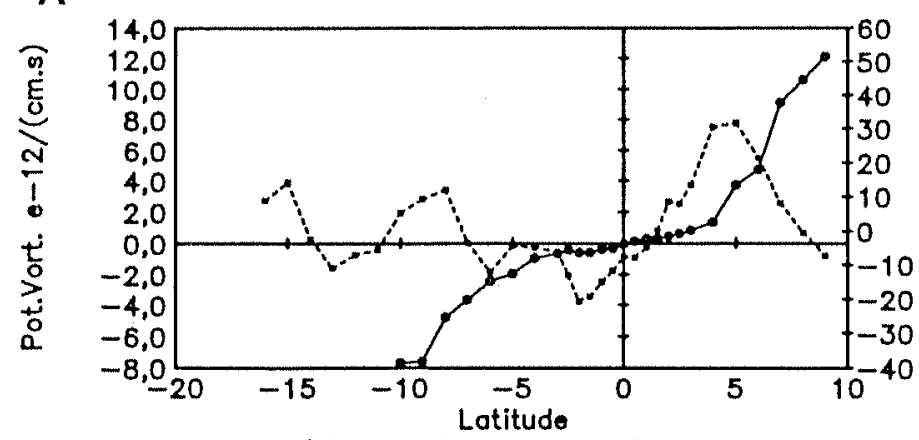

$\rightarrow$ Potential Vorticity -.. Velocity

B

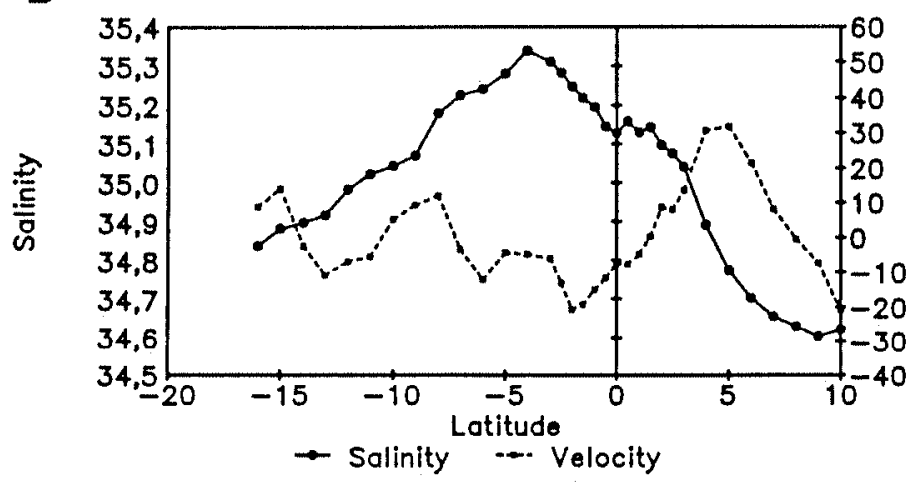

C $142 \cdot E$ - Sigma-Theta 22.5

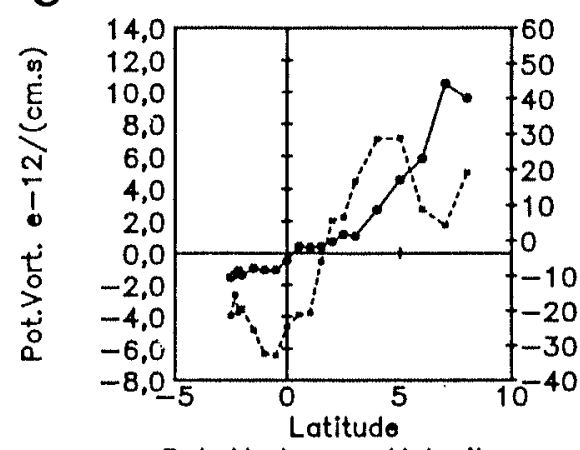

$\rightarrow$ Pot. Vort. -.- Volocity

D

142.E - Sigma-Theta 22.5

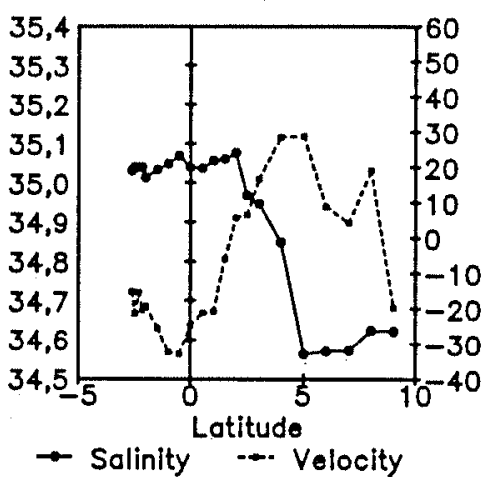

E $\quad 137 \cdot E$ - Sigma-Theta 22.5

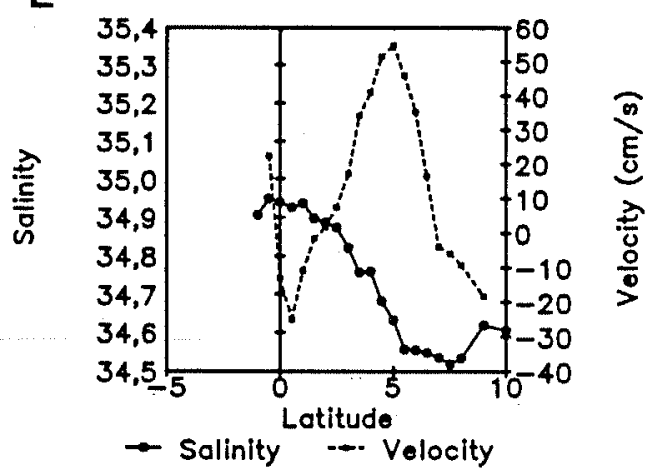

Fig. 9. Distribution of the mean zonal velocity in $\mathrm{cm} \mathrm{s}^{-1}$, mean salinity in psu, and mean potential vorticity $\left(\left(f-U_{y}\right) E\right)$ in $10^{-12} \mathrm{~cm}^{-1}$ $\mathrm{s}^{-1}$ on $22.5 \mathrm{mg} \mathrm{cm}^{-3}$ potential density anomaly. Potential vorticity is not estimated in the surface layer and so does not appear south of $10^{\circ} \mathrm{S}$. (a) Potential vorticity and mean zonal velocity along $165^{\circ} \mathrm{E}$. (b) Salinity and mean zonal velocity along $165^{\circ} \mathrm{E}$. (c) Potential vorticity and mean zonal velocity along $142^{\circ} \mathrm{E}$. (d) Salinity and mean zonal velocity along $142^{\circ} \mathrm{E}$. (e) Salinity and zonal geostrophic current relative to 600 dbar along $137^{\circ} \mathrm{E}$.

anomaly surface, the stronger meridional salinity gradient north of the equator is found at the same latitude on the three sections (between $2^{\circ}$ and $3^{\circ} \mathrm{N}$ ) (Figures $11 b, 11 d, 11 e$ ). The gradient maximum lies near the core of the northern Subsurface Countercurrent. A comparable, albeit weaker, feature is seen within the southern Subsurface Countercurrent at $165^{\circ} \mathrm{E}$ (Figure $11 b)$. Near the equator, in the Equatorial Intermediate Current, salinity varies less strongly with latitude. This is particularly true at $165^{\circ} \mathrm{E}$ (Figure $11 b$ ). That tendency for a maximum meridional gradient in the eastward currents and minimum salinity gradient in westward currents is also found in the potential vorticity distribution. The similarity is particularly evident at $165^{\circ} \mathrm{E}$ (compare Figures $11 a$ and $11 b$ ). The velocity profiles do not extend deep enough at $142^{\circ} \mathrm{E}$ to compute the relative vorticity (and the potential vorticity) on the $26.7 \mathrm{mg} \mathrm{cm}^{-3}$ surface. Hence we display the $26.6 \mathrm{mg} \mathrm{cm}^{-3}$ surface in Figure $11 c$, where the shift of the maximum gradient of potential vorticity from the equator to the latitude of the northern Subsurface Countercurrent is already noticeable.

A striking feature of the $165^{\circ} \mathrm{E}$ distributions on the $26.7 \mathrm{mg}$ $\mathrm{cm}^{-3}$ surface is the region between the Subsurface Countercurrents where $Q$ values are nearly constant and the meridional salinity gradient is reduced. These distributions are somewhat reminiscent of solutions discussed by Rhines and Young [1982] in which $Q$ is homogenized within closed gyres. Pushing the analogy, we suppose similar physics might apply to 
A

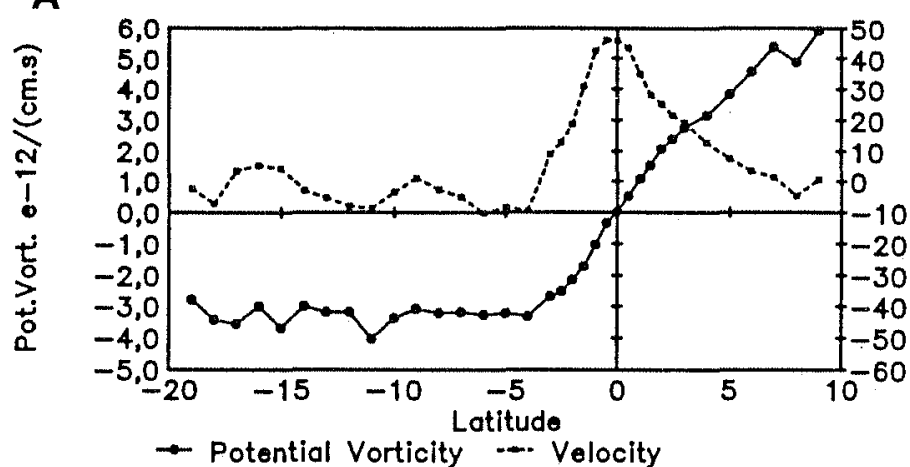

B

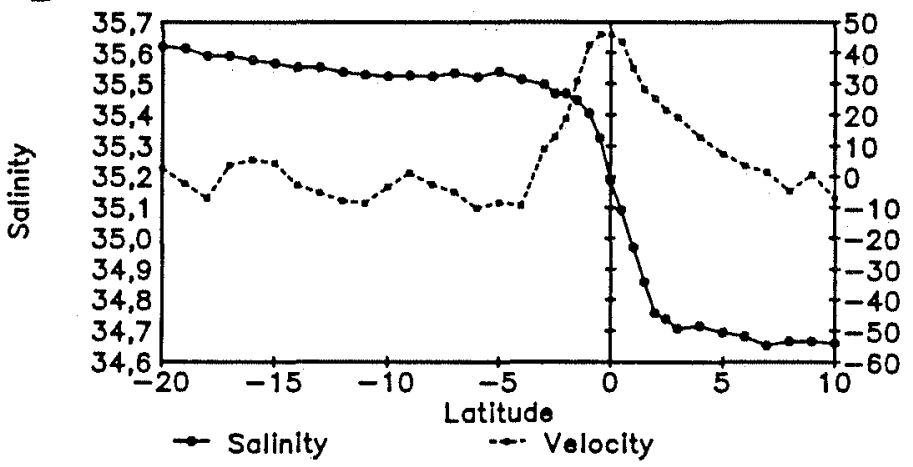

C $142 \cdot E$ - Sigma-Theta 25.5

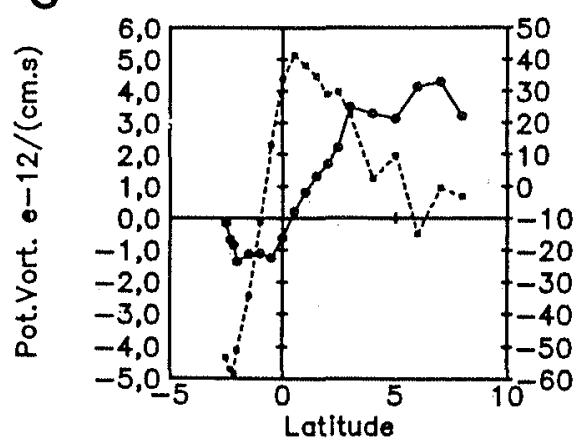

$\rightarrow$ Pot. Vort. -.. Velocity

D

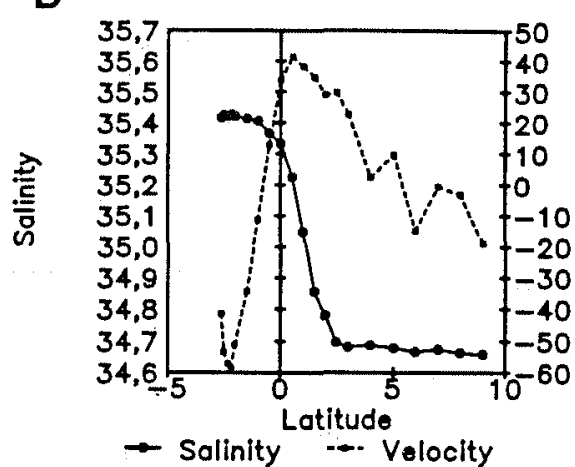

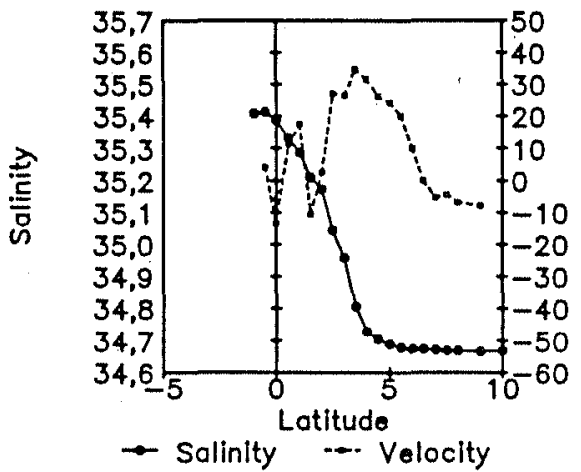

$$
\begin{aligned}
& \text { हn } \\
& \frac{E}{0} \\
& \frac{1}{0} \\
& \frac{0}{0}
\end{aligned}
$$

Fig. 10. Same as Figure 9 for the $25.5 \mathrm{mg} \mathrm{cm}^{-3}$ potential density anomaly surface.

the situation where the Equatorial Intermediate Current and equatorward parts of the Subsurface Countercurrents form zonal recirculation cells (i.e., the westward transport of the Intermediate Current returns eastward as part of the Subsurface Countercurrents). We have no evidence for such flow paths aside from the property distributions that would seem to limit meridional exchange at latitudes $2-3^{\circ}$, and the continuity constraint.

Contrary to what was observed on the $25.5 \mathrm{mg} \mathrm{cm}^{-3}$ isopycnal, potential vorticity at $165^{\circ} \mathrm{E}$ is not constant between $20^{\circ} \mathrm{S}$ and $5^{\circ} \mathrm{S}$. At these depths, the pycnocline strength changes with latitude, rather than compensating for $f$, actually weakens from $20^{\circ} \mathrm{S}$ to $5^{\circ} \mathrm{S}$ (Figure $3 a$ ), accentuating the meridional gradient of potential vorticity.

A relative salinity maximum is seen on the $26.7 \mathrm{mg} \mathrm{cm}^{-3}$ isopycnal between about $5^{\circ}$ and $7^{\circ} \mathrm{N}$ (Figures $11 \mathrm{~b}, 11 \mathrm{~d}, 11 \mathrm{e}$ ).
This maximum is associated with a relative minimum in the eastward current, or even a westward current, as at $142^{\circ} \mathrm{E}-6^{\circ} \mathrm{N}$ $\left(-10 \mathrm{~cm} \mathrm{~s}^{-1}\right)$. Tsuchiya et al. [1989] noticed that this salinity maximum is associated with a minimum of oxygen at $143^{\circ} \mathrm{E}$ and $155^{\circ} \mathrm{E}$. With weak advection, vertical mixing with the overlying saltier waters and in situ consumption could give rise to the observed property extrema. It is possible that the relevant feature is actually the relative salinity minimum at $4^{\circ} \mathrm{N}-5^{\circ} \mathrm{N}$. Reid [1965] traced the low-salinity tongue of North Pacific Intermediate Water, on the $125 \mathrm{cl} \mathrm{t}^{-1}$ surface southward along the Mindanao coast then eastward along $4^{\circ} \mathrm{N}$ to $144^{\circ} \mathrm{E}$ (cf Reid's Figure 19). F. Bingham and R. Lukas (unpublished manuscript, 1993) and Toole et al. [1988] also noticed this feature in more recent measurements off the Mindanao coast. They suggest that North Pacific Intermediate Water is carried west by the North Equatorial Current. At the North Equatorial Current bifurcation, 
A $165 \cdot E$ - Sigma-Theto 26.7

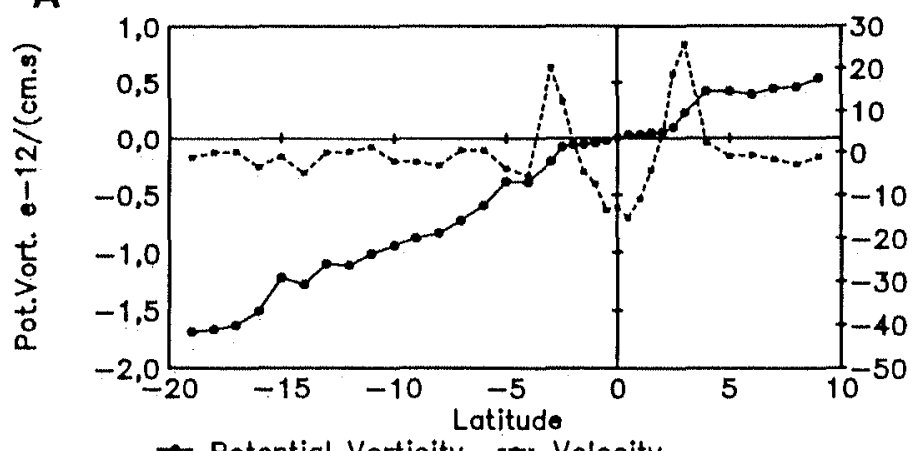

$\rightarrow$ Potential Vorticity -... Velocity

B

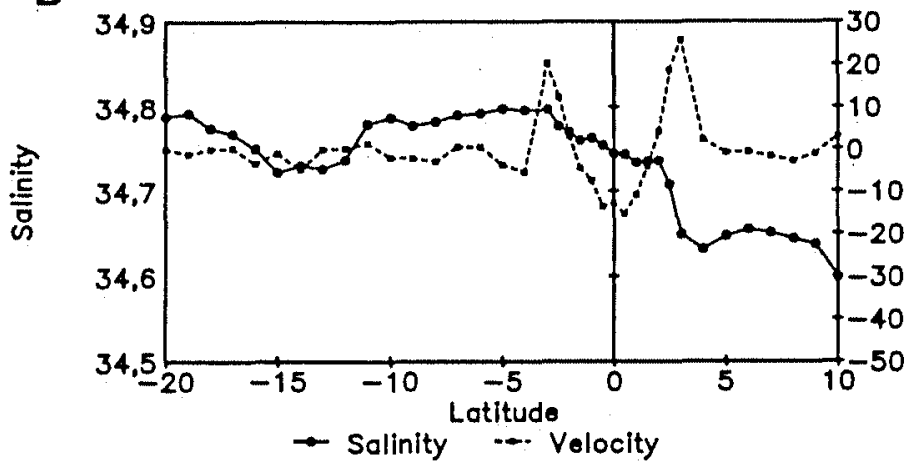

C $\quad 142 \cdot E$ - Sigma-Theto 26.6

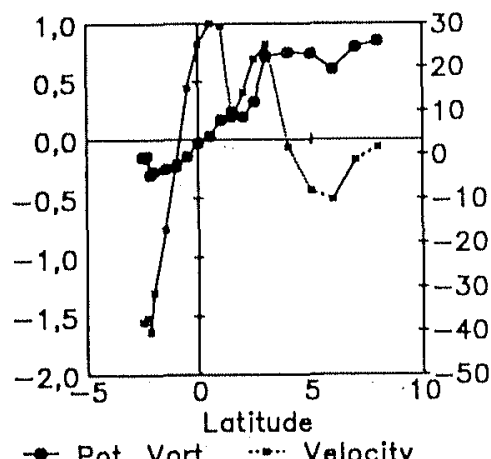

Pot. Vort. ..... Velocity

142.E - Sigma-Theto 26.7

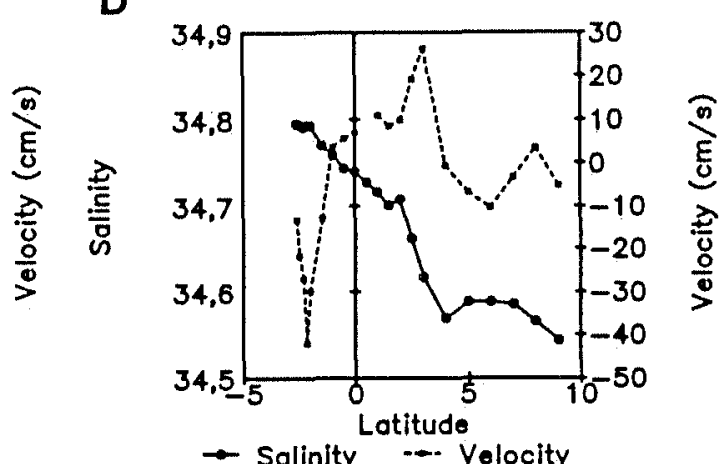

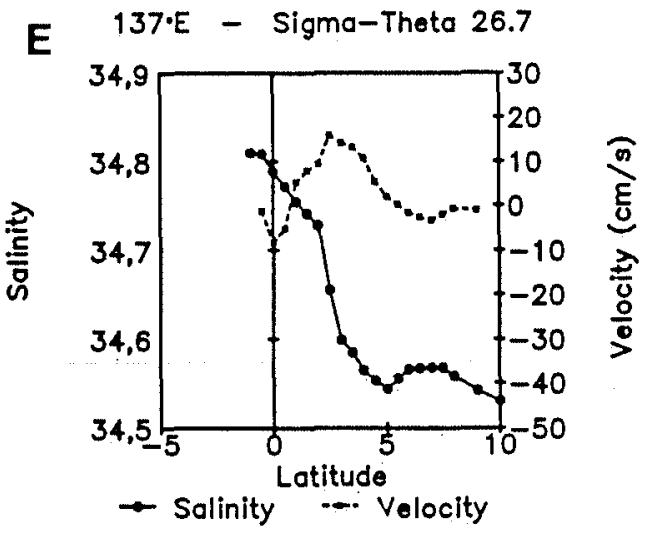

Fig. 11. Same as Figure 9 for the $26.7 \mathrm{mg} \mathrm{cm}^{-3}$ potential density anomaly surface, except for Figure $11 c$ where potential vorticity and zonal velocity are drawn on the surface $26.6 \mathrm{mg} \mathrm{cm}^{-3}$ (see text).

some of the low-salinity waters head south with the Mindanao current, and the rest north as the Kuroshio. The southward branch is hypothesized to turn back east to supply a part of the northern Subsurface Countercurrent, carrying along the low-salinity signature. The increase of salinity of this minimum from $137^{\circ} \mathrm{E}\left(34.544\right.$ at $\left.5^{\circ} \mathrm{N}\right)$ to $165^{\circ} \mathrm{E}\left(34.632\right.$ at $\left.4^{\circ} \mathrm{N}\right)$ is likely the result of mixing as fluid parcels move eastward.

The distribution of salinity on the $26.7 \mathrm{mg} \mathrm{cm}^{-3}$ surface south of the equator on $165^{\circ} \mathrm{E}$ is characterized by a broad maximum centered about $5^{\circ} \mathrm{S}$ and a local minimum between $11^{\circ}$ and $16^{\circ} \mathrm{S}$; farther south, salinity increases again, reaching values at $19^{\circ}$ $20^{\circ} \mathrm{S}$ that are comparable to the maximum at $5^{\circ} \mathrm{S}$. The potential vorticity distribution at these latitudes exhibits a monotonic increase toward the equator (principally driven by $f$ ) but with an inflection about the latitude of the salinity minimum. This salin- ity minimum was previously examined by Reid [1965] on the $125 \mathrm{cl} \mathrm{t}^{-1}$ surface (approximately $26.8 \mathrm{mg} \mathrm{cm}^{-3}$ potential density anomaly surface, some $30 \mathrm{~m}$ deeper than the $26.7 \mathrm{mg} \mathrm{cm}^{-3}$ surface examined here). In his Figure 19, Reid shows low-salinity influence on this density surface emanating from its surface outcrop in the southeast Subantarctic Pacific $\left(50-60^{\circ} \mathrm{S}\right)$, and extending equatorward then westward around the subtropical gyre of the South Pacific. Salinities within this tongue increase with distance away from the outcrop region, presumably due to vertical mixing with the overlying Tropical Water. Reid [1965] comments that this mixing might be enhanced around the islands of the Solomons and Vanuatu, as salinity values increase abruptly through this area. The minimum is, however, well defined at $165^{\circ} \mathrm{E}$ (west of the island arc: $34.726 \mathrm{psu}$ at $13^{\circ} \mathrm{S}$ on the $26.7 \mathrm{mg}$ $\mathrm{cm}^{-3}$ surface versus the $5^{\circ} \mathrm{S}$ maximum of 34.798 ). Furthermore, 
the departure of the mean $Q$ distribution from the planetary variation with latitude indicates the salinity minimum at $165^{\circ} \mathrm{E}$ is still an advective feature, as it is associated with a mean zonal current.

\section{VARIABIIITY}

\subsection{Sea Surface Dynamic Height}

The series of cruises provide some information about the variability of the circulation in the western Pacific on annual and interannual time scales. To be more specific about the events which occurred along $165^{\circ} \mathrm{E}$ between 1984 and 1991 , we analyzed the temporal evolution of the sea surface dynamic height (Figure 12) (Delcroix et al. [1992] examine the variability in much greater detail.) In the mean, from north to south, there appears the well-known succession of troughs and ridges in surface dynamic height which delimit the main currents of the equatorial Pacific Ocean [Wyrtki, 1974; Toole et al., 1988; Delcroix et al., 1992]. Obviously, strong variability occurred during the $71 / 2$ year period under analysis. The temporal and spatial variations of the dynamic height were synthesized by an empirical orthogonal function (EOF) analysis, using the 6month averaged data discussed above (EOFs were computed for the departures from the 1984-1991 mean dynamic height variation with latitude). The first EOF, representing $43 \%$ of the variance, has sea surface dynamic height fluctuations in phase between $20^{\circ} \mathrm{S}$ and $10^{\circ} \mathrm{N}$ (Figure 13a). (Qiu and Joyce [1992] found similar in-phase variation along $137^{\circ} \mathrm{E}$ between $2^{\circ} \mathrm{N}$ and $18^{\circ} \mathrm{N}$.) The time function of the first mode clearly shows the anomaly of the 1986-1987 El Niño with a peak in the July 1987 period (Figure 13b). There is also a negative extremum in 1984 where the sea surface dynamic height has nearly the same value as in 1987 (Figure 12). A time-latitude plot of the sea surface dynamic height (reference $400 \mathrm{~m}$ ), computed from expendable bathythermograph (XBT) measurements, in the western Pacific [Tournier, 1989, Figure 7] showed that after the 1982-1983 El Niño, the values were lower in 1984 than the mean seasonal cycle between $5^{\circ} \mathrm{N}$ and $5^{\circ} \mathrm{S}$. It was not before the beginning of 1985 that the sea surface dynamic height returned to normal values (above $1.9 \mathrm{~m}$ dyn; Figure 12). This slow recovery can also be observed after the 1986-1987 El Niño: it was not before 1990 that the sea surface dynamic height became larger than 1.9 $\mathrm{m}$ dyn at the equator. The time function of the first EOF hints at a seasonal cycle; values in January are generally low with high values in July (Figure 13b). The EOF analysis was repeated after removing the mean seasonal cycle (the average of the January period and the average of the July period was subtracted from the respective cruise dynamic height data), to obtain a clearer pattern of the interannual variability. The first EOF, which again explains about half the variance (44\%), is single signed from $20^{\circ} \mathrm{S}$ to $10^{\circ} \mathrm{N}$ and shows high values in 1984 and during the 1987 E1 Niño event (Figure 13c). Missing in this time function are the oscillations at twice the sampling period (Figure 13d).

It must be noted that the amplitude of the second EOF structure function (which accounts for $18 \%$ of the variance) is very low between $10^{\circ} \mathrm{N}$ and $5^{\circ} \mathrm{S}$, compared to the amplitude of the first EOF, but is of the same order of magnitude south of $5^{\circ} \mathrm{S}$ (not shown). The first EOF therefore does not explain a large part of the variance south of $5^{\circ} \mathrm{S}$. If the analysis is restricted to the latitude range $5^{\circ} \mathrm{N}$ to $5^{\circ} \mathrm{S}$, the first EOF represents $81 \%$ of the variance. The spatial pattern and the time function of this mode are very close to those shown in Figure 13a. This EOF analysis suggests the shipboard sampling at $165^{\circ} \mathrm{E}$ resolved long-period, large latitudinal-scale fluctuations associated with ENSO.

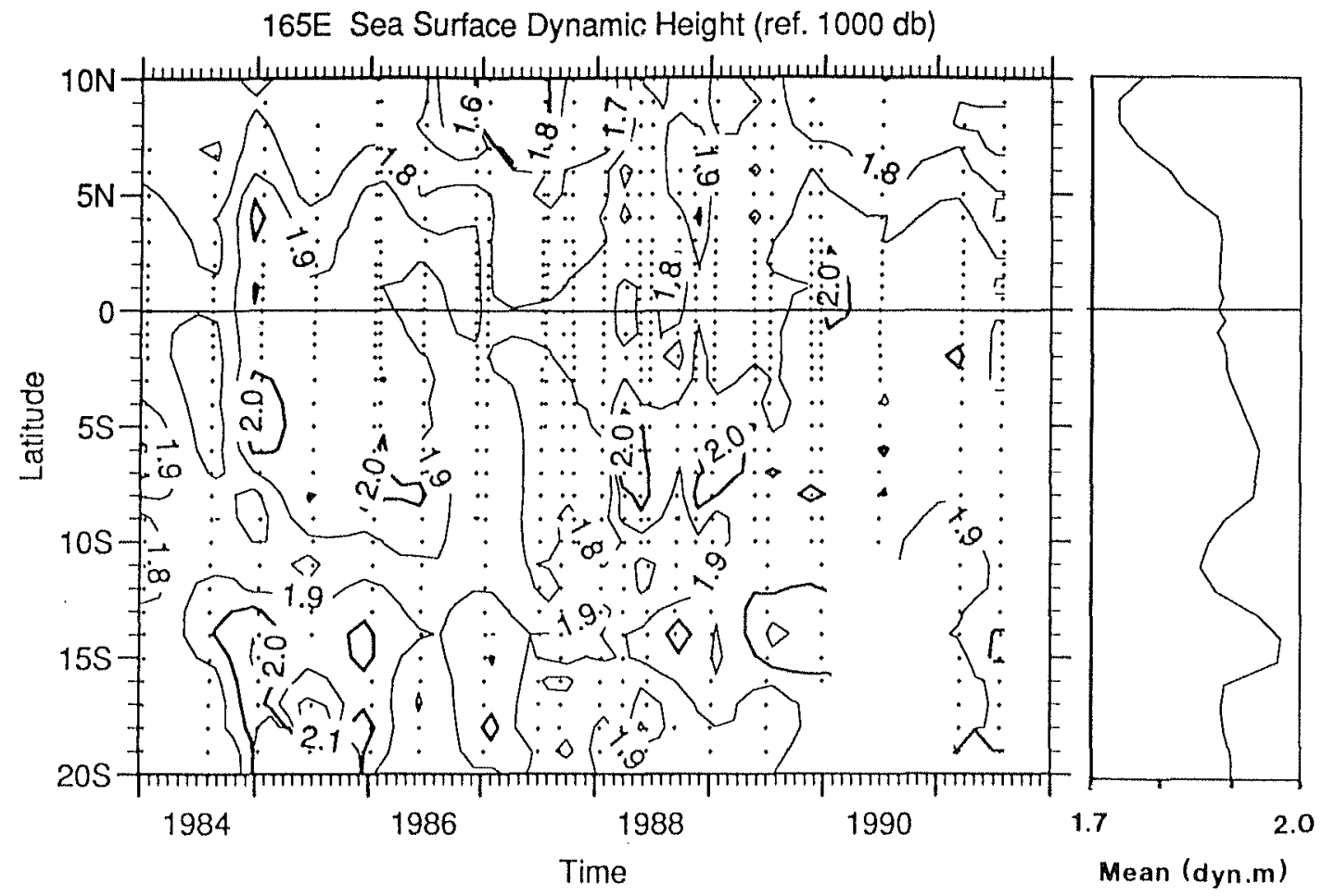

Fig. 12. Time-latitude diagram of the sea surface dynamic height in dyn m relative to 1000 dbar, The curve in the panel to the right of the contour plot is the mean (1984-1991) sea surface dynamic height relative to 1000 dbar. 

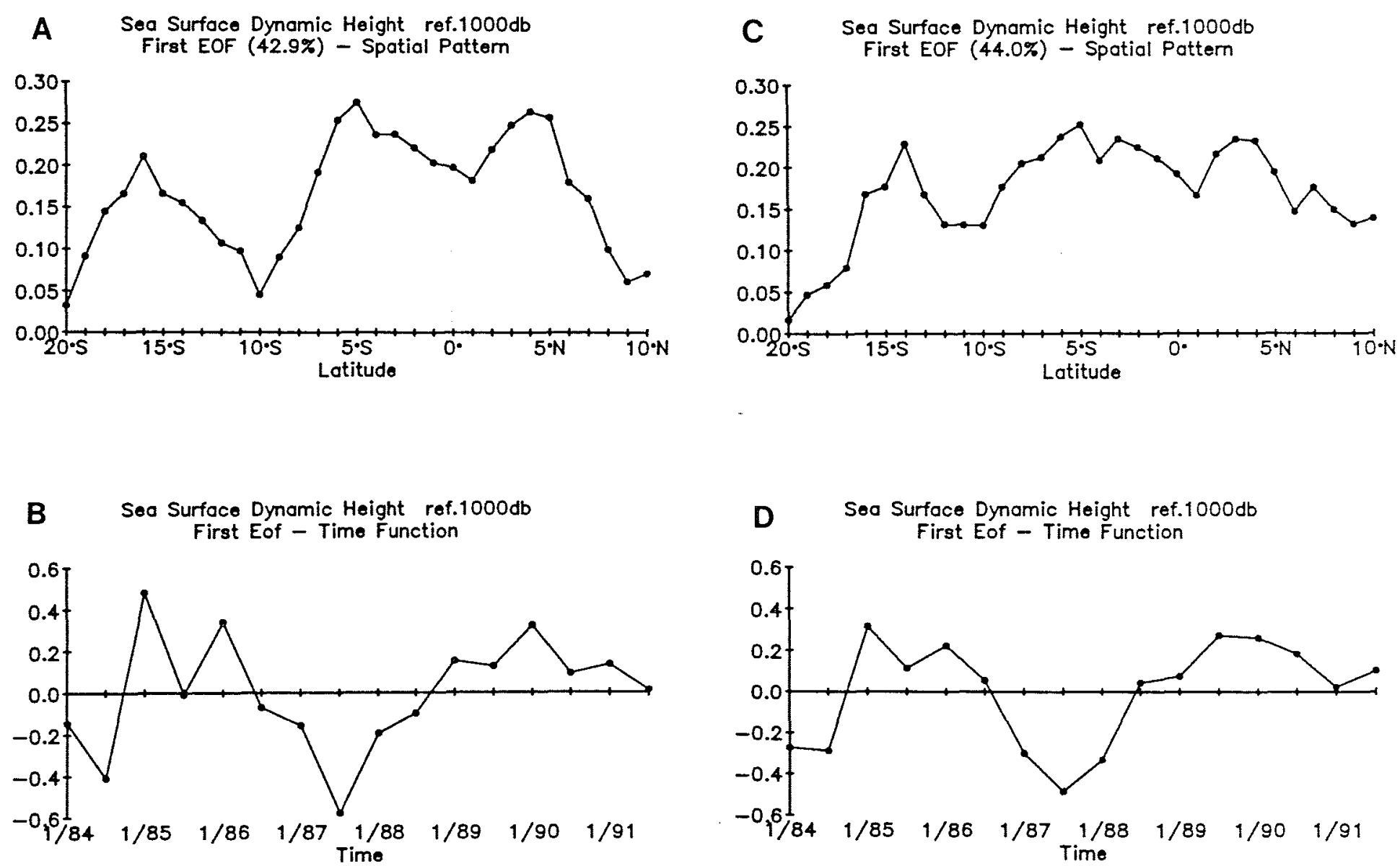

Fig. 13. First empirical orthogonal function (EOF) of the sea surface dynamic height relative to 1000 dbar with $(a, c)$ spatial pattern and $(b, d)$ time function. $(a, b)$ EOF computed for the departures from the 1984-1991 mean dynamic height variation with latitude. $(c, d)$ EOF computed after removing the mean seasonal cycle. 


\subsection{Velocity and Transport}

The temporal distribution of the cruises also allowed us to explore the seasonal differences in the zonal component of velocity at $165^{\circ}$ and $137^{\circ} \mathrm{E}$ (only the geostrophic estimates for the latter). The number of cruises along $142^{\circ} \mathrm{E}$ was not sufficient to perform such a comparison. At $165^{\circ} \mathrm{E}$ the qualitative agreement between the measured and the geostrophic velocities is good for both seasons (Figure 14). Both fields show the meridional extent of the North Equatorial Countercurrent is much greater in July than January. The Countercurrent is found between $9^{\circ} \mathrm{N}$ and $0^{\circ}$ in July $\left(7.5^{\circ} \mathrm{N}\right.$ and $1.5^{\circ} \mathrm{N}$ geostrophically), and between $8.5^{\circ} \mathrm{N}$ and $3^{\circ} \mathrm{N}$ in January $\left(9^{\circ} \mathrm{N}\right.$ and $4^{\circ} \mathrm{N}$ geostrophically). The seasonal meridional displacement of the Countercurrent is more clearly seen by following its surface velocity maximum. The core of this current is found between $4^{\circ} \mathrm{N}$ and $5^{\circ} \mathrm{N}$ in July and between $6^{\circ} \mathrm{N}$ and $7^{\circ} \mathrm{N}$ in January. This meridional displacement of the core of the North Equatorial Countercurrent was previously noted by Tournier [1989] in geostrophic currents (relative to 400 m) computed from XBT measurements in the western Pacific. She found that the Ekman pumping is the main forcing mechanism for this current. The South Equatorial Countercurrent is found between $8^{\circ} \mathrm{S}$ and $11^{\circ} \mathrm{S}$ in July, and between $5^{\circ} \mathrm{S}$ and $10^{\circ} \mathrm{S}$ in January $\left(6^{\circ} \mathrm{S}\right.$ and $10^{\circ} \mathrm{S}$ from geostrophy). We note that Tournier's [1989] study found this current to lie between $7^{\circ} \mathrm{S}$ and $12^{\circ} \mathrm{S}$ in April-May-June (southernmost extent) and between $5^{\circ} \mathrm{S}$ and $10^{\circ} \mathrm{S}$ in October-November-December (northernmost position). In similar fashion, the position of this current can be explained by the meridional migration of the South Pacific Conyergence Zone [Tournier, 1989].

The most striking feature of the seasonally averaged velocity sections is the relative vertical thickness of the Equatorial Undercurrent and Intermediate Current. The Undercurrent is thicker in July than January (Figure 14). This measure is somewhat difficult to evaluate in July as the Undercurrent is linked to the Countercurrents north of $0^{\circ}$, but this feature is confirmed by the vertical extent of the high velocity core. The maximum speed of the Equatorial Undercurrent is greater in July (54 cm $\mathrm{s}^{-1}$ ), when the Undercurrent is thicker, than in January (43 cm $\left.\mathrm{s}^{-1}\right)$. These results are confirmed by the mooring measurements at $165^{\circ} \mathrm{E}-0^{\circ}$ [McCarty and McPhaden, 1993]. They computed the mean seasonal cycle of the Undercurrent core speeds (current meter at 200-m depth) over the period from January 1986 to January 1992, including the 1986-1987 El Niño event and found that the Undercurrent core speeds are minimum in November $\left(36.2 \mathrm{~cm} \mathrm{~s}^{-1}\right.$, s.d. $\left.17.3 \mathrm{~cm} \mathrm{~s}^{-1}\right)$ and maximum in June $\left(56.5 \mathrm{~cm} \mathrm{~s}^{-1}\right.$, s.d. $\left.10.5 \mathrm{~cm} \mathrm{~s}^{-1}\right)$. Velocities greater than $50 \mathrm{~cm} \mathrm{~s}^{-1}$ are observed between February and July.

The Equatorial Intermediate Current exhibits the opposite behavior. When the Undercurrent has maximum (minimum) velocity and thickness in July (January), the Intermediate Current is narrow (thick) (Figure 14). Core speed is also slower in July $\left(13 \mathrm{~cm} \mathrm{~s}^{-1}\right.$ ) than in January $\left(18 \mathrm{~cm} \mathrm{~s}^{-1}\right.$ ) (a point that is more evident in transport calculations below). This feature cannot be confirmed by the mooring at $165^{\circ} \mathrm{E}-0^{\circ}$ as the deepest measurement is $300 \mathrm{~m}$.

All of these features are present in the geostrophically estimated fields, including the relative strengths of the subsurface equatorial currents. The vertical stretching of the Undercurrent core could have been foreseen from the temperature section which showed a better developed upwelling of the isotherms in the upper part of the thermocline in July than in January (not shown). It is worth noting that the northward extension of the high salinity Tropical Water tongue at 120 dbar, is greater in January $\left(5^{\circ} \mathrm{N}\right.$ for the isohaline 34.9$)$ when the Equatorial Undercurrent is the thinnest, than in July $\left(3.5^{\circ} \mathrm{N}\right.$ for the isohaline 34.9) (not shown).

The transport calculations confirm these features (Table 8). The Equatorial Undercurrent transport increases by a factor of 2 between January $\left(10.7 \times 10^{6} \mathrm{~m}^{3} \mathrm{~s}^{-1}\right)$ and July $\left(21.5 \times 10^{6} \mathrm{~m}^{3} \mathrm{~s}^{-1}\right)$, and the Equatorial Intermediate Current transport is halved (6.3 $\times 10^{6} \mathrm{~m}^{3} \mathrm{~s}^{-1}$ in January, $3.5 \times 10^{6} \mathrm{~m}^{3} \mathrm{~s}^{-1}$ in July). This result is found in both the direct measurements and the geostrophic calculations. On the other hand, there is relatively small variation in transport of the two Subsurface Countercurrents between seasons (Table 8). Measured velocities indicate larger North Equatorial Countercurrent transport in July $\left(28 \times 10^{6} \mathrm{~m}^{3} \mathrm{~s}^{-1}\right)$ than in January $\left(21.2 \times 10^{6} \mathrm{~m}^{3} \mathrm{~s}^{-1}\right)$ which is not confirmed by the geostrophic estimate. Toole et al. [1988] computed the mean geostrophic transport of the North Equatorial Countercurrent (temperature $>12^{\circ} \mathrm{C}$ ) at $160^{\circ} \mathrm{E}$. They found a well-defined seasonal cycle with a minimum transport in March-April-May $\left(13.2 \times 10^{6} \mathrm{~m}^{3} \mathrm{~s}^{-1}\right)$ and a maximum in September-OctoberNovember $\left(41.8 \times 10^{6} \mathrm{~m}^{3} \mathrm{~s}^{-1}\right)$. Their transport estimates during the transition seasons were comparable, $22.3 \times 10^{6} \mathrm{~m}^{3} \mathrm{~s}^{-1}$ in December-January-February and $24.9 \times 10^{6} \mathrm{~m}^{3} \mathrm{~s}^{-1}$ in June-JulyAugust. These later estimations are close to the present geostrophic transport figures for $165^{\circ} \mathrm{E}$ (Table 8). This confirms that the semi-annual SURTROPAC cruises in January and July do not sample the maximum and minimum of the North Equatorial Countercurrent transport (see the appendix).

We find more South Equatorial Current transport in January $\left(37.5 \times 10^{6} \mathrm{~m}^{3} \mathrm{~s}^{-1}\right)$ than in July $\left(25.8 \times 10^{6} \mathrm{~m}^{3} \mathrm{~s}^{-1}\right)$. This difference of $12 \times 10^{6} \mathrm{~m}^{3} \mathrm{~s}^{-1}$ between seasons is also found in the geostrophic computation but with the same drawback as we had with the mean section: geostrophic calculated westward velocities in the South Equatorial Current at the equator are much greater than those measured directly. The South Equatorial Countercurrent also varies significantly between July $\left(3.5 \times 10^{6}\right.$ $\left.\mathrm{m}^{3} \mathrm{~s}^{-1}\right)$ and January $\left(7 \times 10^{6} \mathrm{~m}^{3} \mathrm{~s}^{-1}\right)$. Here the geostrophic estimates are very close to the measured values (Table 8 ).

Geostrophic velocities referred to 600 dbar in July and January along $137^{\circ} \mathrm{E}$ are shown on Figure 15 . Both seasons show the presence of an eastward current north of the equator between $0.5^{\circ} \mathrm{N}$ and $1^{\circ} \mathrm{N}$. It is only in January that there is a welldefined subsurface maximum of eastward velocity that can be identified as the Equatorial Undercurrent. No estimation of Undercurrent transport has been made for July as there is no subsurface maximum of eastward velocity. The transport estimate of the Equatorial Undercurrent in January is $12.4 \times 10^{6} \mathrm{~m}^{3}$ $\mathrm{s}^{-1}$, which is reduced when the velocities are referenced to 1000 dbar $\left(5.7 \times 10^{6} \mathrm{~m}^{3} \mathrm{~s}^{-1}\right.$ ) (Table 5). Seasonal differences in the North Equatorial Countercurrent transport are notable; it is larger in July $\left(52.5 \times 10^{6} \mathrm{~m}^{3} \mathrm{~s}^{-1}\right)$ than in January $\left(34.9 \times 10^{6} \mathrm{~m}^{3}\right.$ $\mathrm{s}^{-1}$ ). The difference between seasons is reduced with a $1000 \mathrm{dbar}$ reference: $56.3 \times 10^{6} \mathrm{~m}^{3} \mathrm{~s}^{-1}$ in July versus $44.8 \times 10^{6} \mathrm{~m}^{3} \mathrm{~s}^{-1}$ in January. For the same period (1972-1985) we computed the North Equatorial Countercurrent transport from the individual cruise estimates of Qiu and Joyce [1992]. It gave a transport of $55.4 \times 10^{6} \mathrm{~m}^{3} \mathrm{~s}^{-1}$ (s.d. $18.2 \times 10^{6} \mathrm{~m}^{3} \mathrm{~s}^{-1}$ ) in July, and $48.6 \times 10^{6}$ $\mathrm{m}^{3} \mathrm{~s}^{-1}$ (s.d. $18.6 \times 10^{6} \mathrm{~m}^{3} \mathrm{~s}^{-1}$ ) in January. Information about the annual cycle of the North Equatorial Countercurrent transport at that longitude is sparse. The historical analysis of hydrographic data by Toole et al. [1988] found no significant seasonal variability of the North Equatorial Countercurrent geostrophic transport (temperature $>12^{\circ} \mathrm{C}$ ) on their $133^{\circ} \mathrm{E}$ section with a 

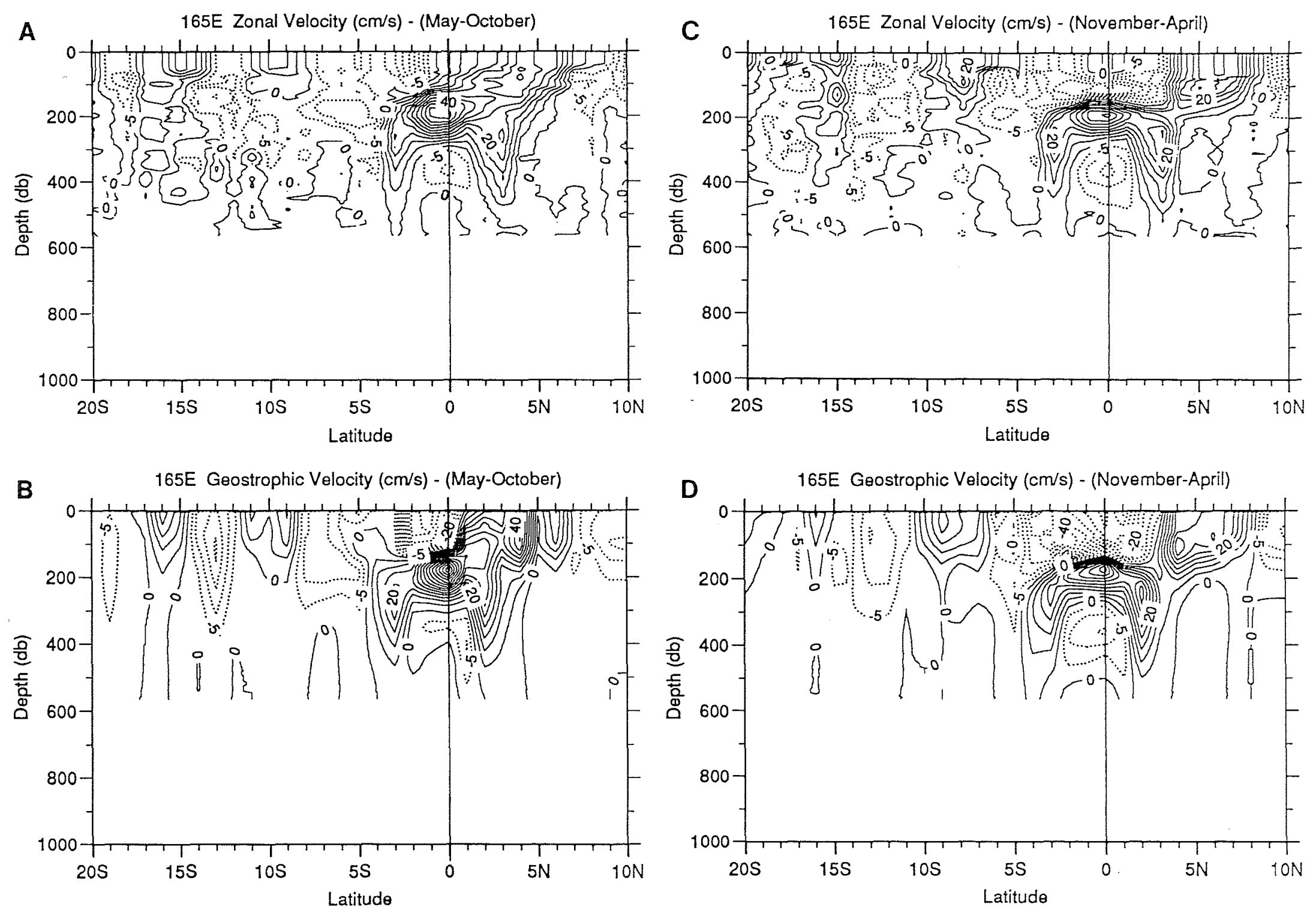

Fig. 14. Mean meridional sections of zonal velocity in $\mathrm{cm} \mathrm{s}^{-1}$ along $165^{\circ} \mathrm{E}$. (a) Direct measurements for the period May-October. (b) Geostrophic estimation relative to $600 \mathrm{dbar}$ for the period May-October. (c) Direct measurements for the period NovemberApril. (d) Geostrophic estimation relative to $600 \mathrm{dbar}$ for the period November-April. Solid contours denote eastward flow. 
TABLE 8. Mean Transport at $165^{\circ} \mathrm{E}$ in $10^{6} \mathrm{~m}^{3} \mathrm{~s}^{-1}$

\begin{tabular}{lccccc}
\hline & \multicolumn{2}{c}{ July } & & \multicolumn{2}{c}{ January } \\
\cline { 2 - 3 } \cline { 5 - 6 } & $\begin{array}{c}\text { Direct } \\
\text { Measurement }\end{array}$ & $\begin{array}{c}\text { Geostrophy* } \\
\text { /600 dbar }\end{array}$ & $\begin{array}{c}\text { Direct } \\
\text { Measurement }\end{array}$ & $\begin{array}{c}\text { Geostrophy* } \\
\text { /600 dbar }\end{array}$ \\
\hline STCC & 12.5 & 4.4 & 6.0 & 2.4 \\
SEC 2 & -3.9 & -3.0 & & -6.1 & -1.7 \\
SECC & 3.5 & 3.8 & 6.7 & 7.7 \\
SEC & -25.8 & -36.1 & & -37.5 & -49.5 \\
SSCC & 8.2 & 8.0 & & 7.9 & 5.9 \\
EUC & 21.5 & 21.8 & & 10.7 & 12.3 \\
EIC & -3.5 & -3.0 & & -6.2 & -6.8 \\
NSCC & 10.7 & 12.1 & & 11.1 & 10.2 \\
NECC & 28.0 & 23.2 & & 21.2 & 22.3 \\
\hline
\end{tabular}

STCC, South Tropical Countercurrent; SEC, South Equatorial Current; SECC, South Equatorial Countercurrent; SSCC, Southern Subsurface Countercurrent; EUC, Equatorial Undercurrent; EIC, Equatorial Intermediate Current; NSCC, Northern Subsurface Countercurrent; NECC, North Equatorial Countercurrent.

* Geostrophic velocity computed every degree of latitude off $1^{\circ} \mathrm{N}$ and $1^{\circ} \mathrm{S}$. reference level of $1000 \mathrm{dbar}$. Whatever the choice of the reference level, the decrease of the North Equatorial Countercurrent transport between $137^{\circ} \mathrm{E}$ and $165^{\circ} \mathrm{E}$ found in the annual mean is reproduced in January and July.

\subsection{Pressure Gradient}

Mangum et al. [1990], analyzing historical data, found that the Zonal Pressure Gradient (ZPG) referenced to $500 \mathrm{~m}$ in the western equatorial Pacific varied in phase with the monsoonal winds. Their study utilized data within $1^{\circ}$ latitude of the equator between two longitude bands: $153^{\circ} \mathrm{E}-170^{\circ} \mathrm{E}$ and $128^{\circ} \mathrm{E}-138^{\circ} \mathrm{E}$. They found that positive surface ZPG $\left(2.9 \pm 0.410^{-7} \mathrm{~m} \mathrm{~s}^{-2}\right)$ accompanied the westerly wind maximum in boreal winter and negative surface ZPG $\left(-1.7 \pm 0.210^{-7} \mathrm{~m} \mathrm{~s}^{-2}\right)$ was associated with the easterly maximum in boreal summer. The zonal sections along $165^{\circ} \mathrm{E}$ and $137^{\circ} \mathrm{E}$ confirm this result (Figure 16). At the equator, the $\mathrm{ZPG}$ at the sea surface (computed with a reference at $600 \mathrm{dbar}$ ) is $1.6 \times 10^{-7} \mathrm{~m} \mathrm{~s}^{-2}$ in January and $-2.2 \times 10^{-7} \mathrm{~m} \mathrm{~s}^{-2}$ in July.

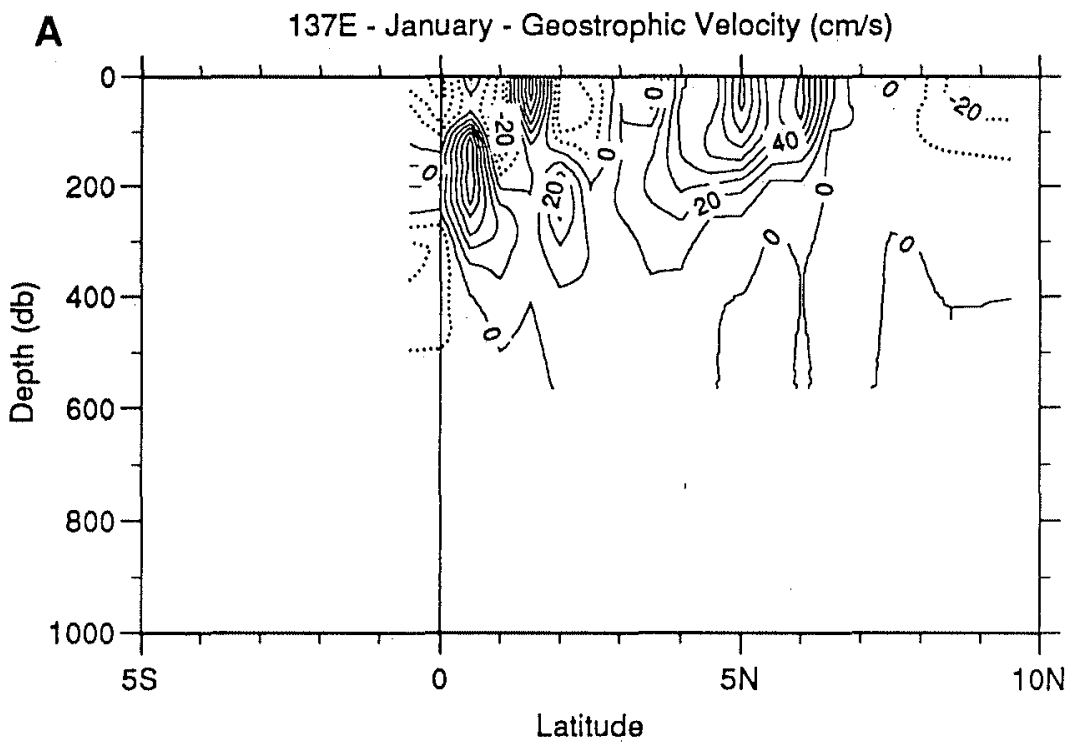

B

137E - July - Geostrophic Velocity (cm/s)

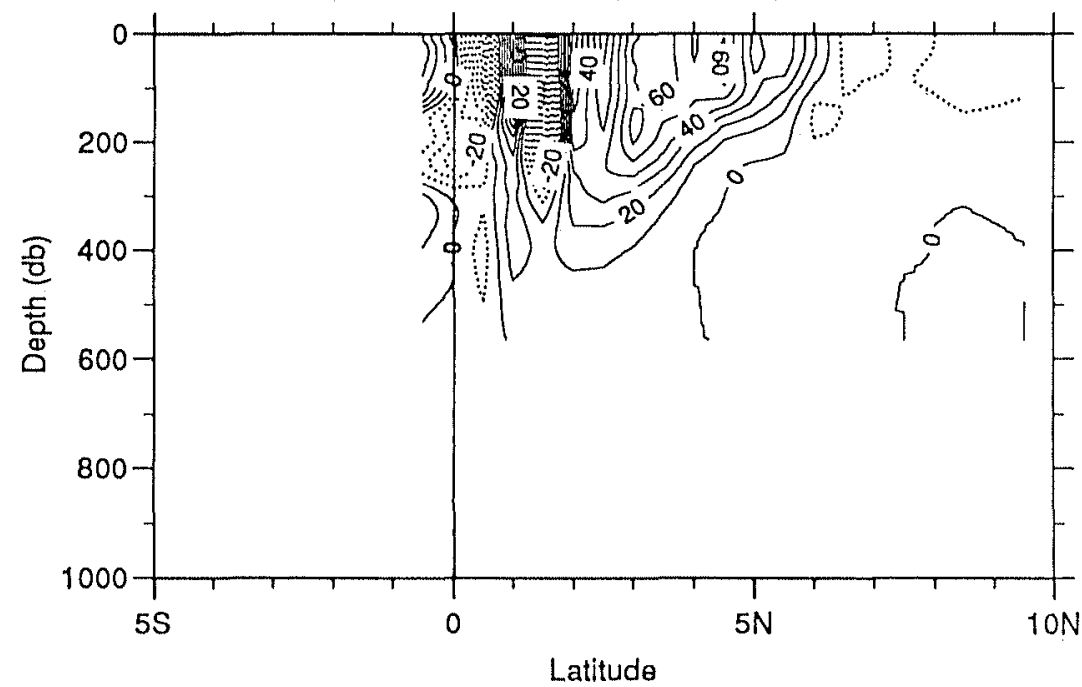

Fig. 15. Mean zonal geostrophic velocity in $\mathrm{cm} \mathrm{s}^{-1}$ relative to 600 dbar along $137^{\circ} \mathrm{E}$ in (a) January and (b) July. Solid contours denole eastward flow. 
A January - ZPG (165E-137E) 10-7 m.s**2

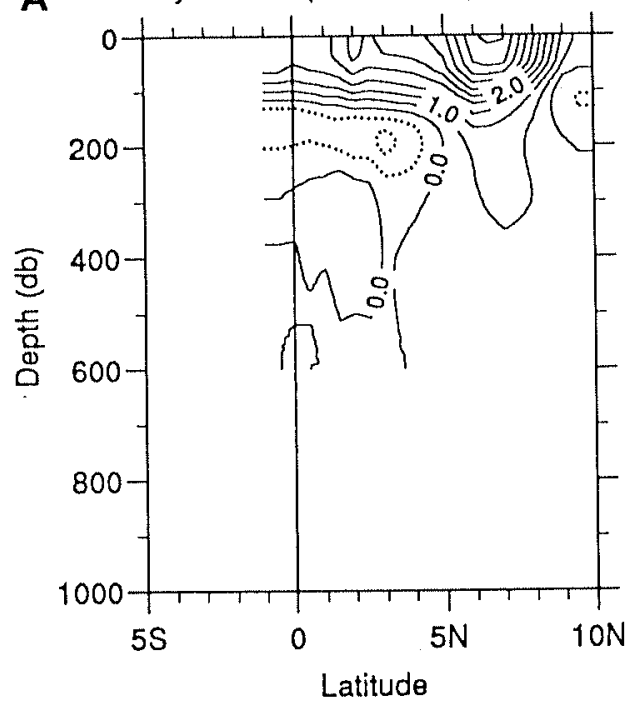

B July - ZPG (165E-137E) 10-7 m.s*2

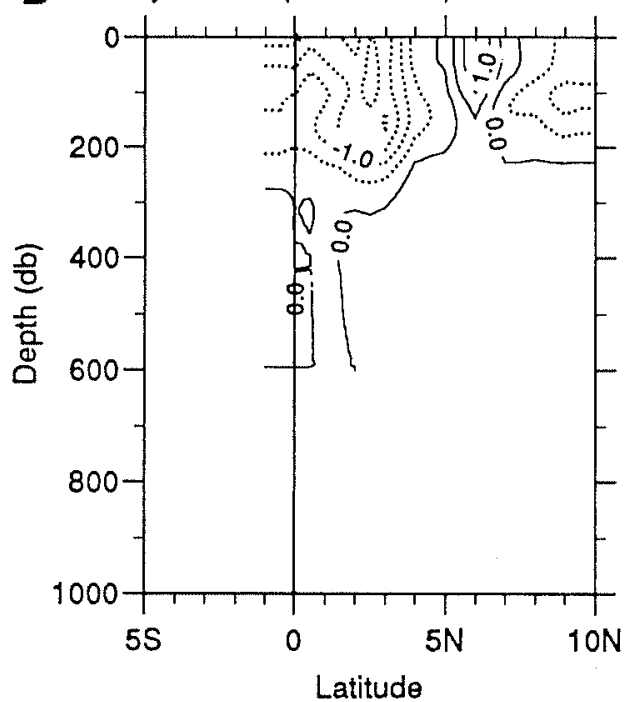

Fig, 16. Mean zonal pressure gradient in $10^{-7} \mathrm{~m} \mathrm{~s}^{-2}$ relative to $600 \mathrm{dbar}$ between $165^{\circ} \mathrm{E}$ and $137^{\circ} \mathrm{E}$ in (a) January, and (b) July. Solid contours denote positive zonal pressure gradient.

The vertical structure of the ZPG is quite different in the two seasons. In July, the ZPG is negative to $300 \mathrm{dbar}$ and then slightly positive below. This vertical structure differs somewhat from that reported by Mangum et al. [1990]. They found, in boreal summer, a significant negative pressure gradient from the sea surface to $400 \mathrm{~m}$ before it crossed zero at $500 \mathrm{~m}$, the reference level they chose. They concluded that the observed westward currents below $300 \mathrm{~m}$ (e.g., the Equatorial Intermediate Current) would flow against the ZPG. The present analysis, which finds a zero crossing at $300 \mathrm{dbar}$, removes this discrepancy. In January we obtained a similar vertical profile as shown by Mangum et al. [1990], that is to say, a negative pressure gradient is deduced at the level of the Equatorial Undercurrent, although the wind has a strong eastward component. This ZPG has been computed over $28^{\circ}$ of longitude and thus cannot be the exact representation of the mean pressure gradient at $137^{\circ} \mathrm{E}$ or $165^{\circ} \mathrm{E}$. Nevertheless, it shows that even though the wind stress reverses direction seasonally, its influence does not extend deep enough to directly influence the Undercurrent.

\section{Discussion ANd Conclusion}

We have been able to build a mean section of temperature, salinity and velocity along $165^{\circ} \mathrm{E}$ between $20^{\circ} \mathrm{S}$ and $10^{\circ} \mathrm{N}$ that, we believe, is representative of the average hydrographic conditions in the upper equatorial western Pacific. The 27 sections used in this study spanned 8 years and sampled one major El Niño/La Niña event. Direct measurement of currents during all these sections, but one, allowed us to compute reliable transports which, we find, agree very well with geostrophic estimations. The present transport estimates are uncertain for two main reasons. The first is that we were obliged to extrapolate currents in the upper $20-30 \mathrm{~m}$. We took the velocity profile as constant in the mixed layer, an assumption supported by the $\mathrm{S}$. Wijffels et al. (Direct observations of the Ekman balance at $10^{\circ} \mathrm{N}$ in the Pacific, submitted to J. Phys. Oceanogr., 1993) analysis of the Ekman transport along $10^{\circ} \mathrm{N}$ in the Pacific Ocean (see also Santiago-Mandujano and Firing [1990]), but unsubstantiated closer to the equator. Our second reservation is that the PCM returns relative measurements that were referenced to $600 \mathrm{~m}$. Yet, direct absolute measurements (both moored and from shipboard ADCP's) suggest this zero velocity surface may be close to reality, at least near the equator.

We find indication of the Undercurrent at $137^{\circ} \mathrm{E}-0.75^{\circ} \mathrm{N}$ in the average geostrophic fields. The Equatorial Undercurrent has previously been reported at that longitude from direct measurements of current [Kort et al., 1966; Masuzawa, 1967]. The northern Subsurface Countercurrent is clearly seen at both $165^{\circ} \mathrm{E}$ and $142^{\circ} \mathrm{E}$, separated from the North Equatorial Countercurrent by a minimum in the zonal component of velocity. The Subsurface Countercurrent velocity maximum is located at $3^{\circ} \mathrm{N}$ with the $10 \mathrm{~cm} \mathrm{~s}^{-1}$ isotach reaching $400 \mathrm{dbar}$ or $450 \mathrm{dbar}$. The structure of these currents is quite different at $137^{\circ} \mathrm{E}$, although this section is only $5^{\circ}$ west of $142^{\circ} \mathrm{E}$. The maximum eastward velocity at depth is still at $3^{\circ} \mathrm{N}$ where the $10 \mathrm{~cm} \mathrm{~s}^{-1}$ isotach reaches $420 \mathrm{dbar}$, but there is no indication of a minimum of velocity between the upper and lower parts of the eastward flow. At this longitude, the North Equatorial Countercurrent seems to extend from the sea surface to 400 dbar. Qiu and Joyce [1992] invoked this consolidation of the two flows to rationalize their Countercurrent transport excess above that deduced from wind forcing.

An interesting result of this study is the strong seasonal variation (which includes interannual variability) of Equatorial Undercurrent and Intermediate Current transport at $165^{\circ} \mathrm{E}$. The surprisingly good qualitative and quantitative comparison between the direct measurements and geostrophic estimation enhances our confidence in this result. We kept the same reference level, $600 \mathrm{dbar}$, to compute the geostrophic velocity for both seasons, a choice supported by the comparison with measured velocity. We note the large-scale ZPG is always negative at the depth of the Equatorial Undercurrent, and that there is no variation in the strength of the ZPG at that depth between July and January (Figure 16). With the data at hand it is impossible to link the seasonal variation of the local wind to the variation of the ZPG in the thermocline, especially because the response of the Pacific ocean to seasonal forcing is not an equilibrium response [P hilander and Chao, 1991]. On the other hand, the ZPG in the upper $120 \mathrm{~m}$ reverses sign between the two seasons. During the boreal summer the southeast trade winds are maximum and favorable to upwelling, which could explain the vertical stretching of the upper part of the Equatorial Undercurrent. In boreal winter the winds reverse west of $160^{\circ} \mathrm{E}$, and the ZPG between $165^{\circ} \mathrm{E}$ and $137^{\circ} \mathrm{E}$ reverses at the surface. This leads to a 
convergence of upper waters toward the equator; the resulting downwelling which should occur at the equator could explain the crushing of the Equatorial Undercurrent during that season.

The seasonal variation in transport and maximum velocity of the Undercurrent is opposite to that found by Tournier [1989] from her analysis of XBT in the western Pacific, probably because she used a reference of 400 dbar to compute the geostrophic currents. This reference is right at the depth of the Equatorial Intermediate Current that shows strong seasonal variation in this study. In contrast with the Equatorial Undercurrent and Equatorial Intermediate Current, the Subsurface Countercurrents show no noticeable transport variations between July and January.

In the absence of direct current measurements, equatorial circulation has often been inferred from the distribution of water property extrema such as salinity, dissolved oxygen or nutrients [e.g., Montgomery, 1938; Tsuchiya, 1968]. The present highquality temperature, salinity and velocity measurements combined with a good meridional sampling, permit more precise estimates of property distributions within the major currents of the western equatorial Pacific (Figures 9, 10, 11). The very striking pattern which emerges from this analysis is that the axes of the main eastward currents are associated with strong meridional property gradients, not with property extrema. In the case of the northern Subsurface Countercurrent, a salinity minimum is 10cated at the northern flank of the current, but the southern flank transports relatively high salinity. This pattern is coherent between $137^{\circ} \mathrm{E}$ and $165^{\circ} \mathrm{E}$, over nearly $30^{\circ}$ of longitude. That particular structure of the salinity had previously been noticed by Tsuchiya [1975]: "... a narrow tongue of low salinity $(<34.8)$ extends east along about $5^{\circ} \mathrm{N}$ as far as $98^{\circ} \mathrm{W}$. The axis of the tongue lies within the eastward flow of the counter-current (on the $160 \mathrm{cl} \mathrm{t}^{-1}$ isanosteric) but does not everywhere coincide with the current axis; the intense meridional gradient of salinity on the southern flank of the tongue more nearly coincides with the current axis." This tendency was also noticed by Hayes et al. [1983] at $110^{\circ} \mathrm{W}$. These eastward currents represent a barrier to the northward extension of the tongue of maximum salinity of the South Tropical Waters. In dynamical terms, this is consistent with the meridional distributions of potential vorticity we deduced. Fluid particles are precluded from moving across these currents, giving rise to the property gradients. The role played by strong currents as a barrier to cross-stream exchange had previously been discussed by Bower et al. [1985]. They found that the gradients of temperature, oxygen, and potential vorticity were very large near the axis of the Gulf Stream and that the current acts as a barrier between the Sargasso Sea and the slope waters. Interestingly, it appears that potential vorticity and salinity are more or less homogenized in the westward currents. This is particularly true on the surface $26.7 \mathrm{mg} \mathrm{cm}^{-3}$ at the latitude of the Equatorial Intermediate Current. We found that the relative vorticity contributed significantly to distributions only very close to the equator. This term acted to increase the meridional gradient of planetary vorticity in the Equatorial Undercurrent and decrease the gradient at the depth of the Intermediate Current.

\section{APUENDIX: REPRESENTATIVITY OF TUE MEAN FLOW}

With in general only two realizations per year of the upper ocean stratification and flow, typically in January and July, concern exists whether the average sections at $137^{\circ} \mathrm{E}$ and $165^{\circ} \mathrm{E}$ are a true representation of the mean fields. Two recent studies of the mean thermal field in the western Pacific Ocean bring some information about the seasonal variability of the zonal component of velocity and transport [Toole et al., 1988; Tournier, 1989]. Tournier [1989] built a quasi-meridional section of temperature from XBT measurements over 3 years (1979 to 1981 , with about $2.8 \mathrm{XBT}$ per month per $1^{\circ}$ latitude). The section extends from $20^{\circ} \mathrm{S}$ to $20^{\circ} \mathrm{N}$ and spans a broad range of longitude $\left(150^{\circ} \mathrm{E}-175^{\circ} \mathrm{E}\right)$. Tournier found clear evidence of seasonal variation in the speed of the main currents (geostrophic calculations referred to $400 \mathrm{~m}$ ): (1) The North Equatorial Countercurrent had a maximum velocity in December-January, the minimum being found in May-June, (2) the South Equatorial Current at the equator was maximum in March and minimum in July, and (3) the South Equatorial Countercurrent was maximum in AugustSeptember-October and minimum at the beginning of the year. Toole et al. [1988] computed the geostrophic tranisport of the western Pacific North Equatorial Countercurrent (temperature $>$ $12^{\circ} \mathrm{C}$ ) by season from historical data, finding a well-defined cycle on their $145^{\circ} \mathrm{E}$ and $160^{\circ} \mathrm{E}$ sections with a minimum transport in March-April-May and a maximum transport in SeptemberOctober-November. No significant seasonal variability was found on the $133^{\circ} \mathrm{E}$ section. Moreover, mooring data at $165^{\circ} \mathrm{E}-$ $0^{\circ}$ show that the mean Undercurrent core speeds, computed between January 1986 to January 1992, are maximum in June and minimum in November [McCarty and McPhaden, 1993]. From this review it appears that the semi-annual SURTROPAC cruises in January and July were phased to capture the maxima and minima of the seasonal cycle of all main currents in the western Pacific but the North Equatorial Countercurrent.

An equally serious concern is interannual variability. The $165^{\circ} \mathrm{E}$ mean section is built from measurements between January 1984 and July 1991. During that time period one EI Niño-La Niña episode occurred. Is one episode in 7.5 years a normal frequency? Analysis of the historical record (1803-1987) obtained a mean period between two El-Niño events of 3.8 years (averaged over the years 1803-1987) record [Quinn et al., 1987]. The time difference between the events can vary between 2 and 7 years. That statistic includes all events Quinn et al. classified as moderate, strong and very strong. This period was also found in a coupled atmosphere-ocean model of the tropical Pacific [Cane and Zebiak, 1985]. So if we considered the anomalous conditions that persisted in 1984, plus the 1986-1987 El Niño, it appeared that our mean section has a realistic weighting of ENSO conditions.

Acknowledgments. The bulk of the work reported here was accomplished while Y.Gouriou was visiting the Woods Hole Oceanographic Institution. Support from this institute has been greatly appreciated. Special thanks go to the many officers, crews, and scientists who gathered the high-quality data sets. We wish to thank E. Firing for providing ADCP data acquired during the U.S./P.R.C. cruise, and the SURTROPAC group (ORSTOM - Noumea) for sharing data with us prior to its publication. We also thank Bo Qiu for giving us access to the Japan Meteorological Agency cruises. This work was supported by ORSTOM (Y.G.) and by the National Science Foundation under grant OCE-9 115347 (J.M.T.). Woods Hole Oceanographic Institution contribution 8404

\section{REFERENCES}

Bahr, F., E. Firing, and J. Songnian, Acoustic Doppler current profiling in the western Pacific during the US-PRC TOGA cruises 2,3 and 4 , IIMAR contribution 89-0175, Data Rep. 005, 199 pp., Univ. of Hawaii, Honolulu, 1989. 
Bower, A.S., H.T. Rossby, and J.L. Lillibridge, The Gulf Stream: Barrier or blender?, J. Phys. Oceanogr., 15, 24-32, 1985.

Bridy, E.C., Observations of wave-mean flow interaction in the Pacific Equatorial Undercurrent, Doctoral dissertation WHOl-90-51, $216 \mathrm{pp}$., Woods Hole Oceanogr. Inst./Mass. Inst. of Technol., Woods Hole, 1990.

Cane, M.A., and S.E. Zebiak, A theory for El Nifio and the Southern Oscillation, Science, 228, 1085-1087, 1985

Cook, M., L. Mangurn, R. Millard, G. Lamontagne, S. Pu, J. Toole, Z. Wang, K. Yang, and L. Zhao, Hydrographic observations from the US-PRC cooperative program in the western equatorial Pacific ocean Cruise 1-4, Tech. Rep. WHOI-90-07, 379 pp., Woods Hole Oceanogr. Inst., Woods Hole, Mass., Jan. 1990.

Cox, M.D.; Generation and propagation of 30 day waves in a numerical model of the Pacific, J. Phys. Oceanogr., 10, 1168-1186, 1980.

Delcroix, T., and C. Hénin, Observations of the equatorial intermediate current in the western Pacific Ocean $\left(165^{\circ} \mathrm{E}\right)$, I. Phys. Oceanogr., 18 363-366, 1988

Delcroix, T., G. Eldin, and C. Hénin, Upper ocean water masses and transport in the western tropical Pacific $\left(165^{\circ} \mathrm{E}\right), J$. Phys. Oceanogr. $17,2248-2262,1987$.

Delcroix; T., F. Gallois, F. Masia, and P. Waigna, Rapport de la campagne SURTROPAC 14 à bord du N.O. LE NOROTT (11 mars au 8 avril 1991 , de $20^{\circ} \mathrm{S}$ à $8^{\circ} \mathrm{N}$ le long du méridien $165^{\circ} \mathrm{E}$ ), Rapport de mission, Série Sciences de la Mer, Océanographie Physique, Rep. 4, 117 pp., Centre ORSTOM de Nouméa, New Caledonia, 1991.

Delcroix, T., G. Eldin, M.H. Radenac, J.M. Toole, and E. Firing, Variation of the western equatorial Pacific Ocean, J. Geophy. Res., 97, 5423$5445,1992$.

Duling, W.O., and D.R. Johnson, High resolution current profiling in the Straits of Florida, Deep Sea Res., 19, 259-274, 1972.

Firing, E., Deep zonal currents in the central equatorial Pacific, $J$. Mar. Res., 45, 791-812, 1987.

Hayes, S.P., A comparison of geostrophic and measured velocities in the equatorial undercurrent, J. Mar. Res., 40, Suppl., 219-229, 1982.

Hayes, S.P., J.M. Toole, and L.J. Mangum, Water-mass and transport variability at $110^{\circ} \mathrm{W}$ in the equatorial Pacific, J. Phys. Oceanogr., 13, $153-168,1983$.

Keffer, T., The ventilation of the world's oceans: Maps of the potential vorticity field, J. Phys. Oceanogr., 15, 509-523, 1985.

Kessler, W.S., and B.A. Taft, Dynamic heights and zonal geostrophic transports in the central tropical Pacific during 1979-84, J. Phys. Oceanogr., 17, 97-122, 1987.

Kort, V.G., V.A. Burkov, and K.A. Chekotillo, New data on equatorial currents in the western Pacific, Dokl. Akad. Nauk SSSR, 171, 4-6, 1966.

Lake, B.J., K. Yang, Z. Luizhi, R.C. Millard, S. Pu, J.M. Toole, Z. Wang, and L.H. Mangum, Hydrographic observations from the US/PRC cooperative program in the western equatorial Pacific ocean: Cruises 5-8. Tech. Rep. WHOI-91-19, 408 pp., Woods Hole Oceanogr. Inst., Woods Hole, Mass., 1991.

Lindstrom, E., R. Lukas, R. Fine, E. Firing, S. Godfrey, G. Meyers, and M. Tsuchiya, The western equatorial Pacific Ocean circulation study, Nature, 330, 533-537, 1987.

Lukas; R., Horizontal Reynolds stresses in the equatorial central Pacific, $J$. Geophys. Res., 92, 9453-9463, 1987.

Lukas, R., and E. Firing, The geostrophic balance of the Pacific equatorial undercurrent, Deep Sea Res., 31, 61-66, 1984.

Mangum, L.J., S.P. Hayes, J.M. Toole, Z. Wang, S. Pu, and D. Hu, Thermohaline structure and zonal pressure gradient in the western equatorial Pacific, $J$. Geophys. Res., 95, 7279-7288, 1990.

Mangum, L. J. Lynch, K. McTaggart, L. Stratton, and S Hayes, CTD/O2 data measurements collected on TEW (Transport of Equatorial Waters) cruise, June-August 1987, NOAA Data Rep. ERL PMEL-33, 375 pp., U.S. Government Printing Office, Washington, D.C., June 1991.

Masuzawa, J., An oceanographic section from Japan to New Guinea at $137^{\circ} \mathrm{E}$ in January 1967, Oceanogr. Mag., 19, 95-118, 1967.

Masuzawa, J., Second cruise for CSK, Ryofu Maru, January to March 1968, Oceanogr. Mag., 20, 173-185, 1968.

Masuzawa, J., T. Akiyama, Y. Kawadara, and T. Sawara, Preliminary report of the Ryofu Maru cruise Ry7001 in January-March 1970, Oceanogr. Mag., 22, 1-25, 1970.
McCarty, M.E., and M.J. McPhaden, Mean seasonal cycles and interannual variations at $0^{\circ}, 165^{\circ} \mathrm{E}$ during 1986-1992, NOAA Tech Memo., ERL PMEL-98, 64 pp., 1993.

McPhaden, M.J., S.P. Hayes, L.J. Mangum, and J.M. Toole, Variability in the western equatorial Pacific Ocean during the 1986-1987 Fi Nifo/Southern Oscillation event, J. Phys. Oceanogr., 20, 190-208, 1990.

Merle, J., F. Rotschi, and B. Voituriez, Zonal circulation in the tropical western south Pacific at $170^{\circ} \mathrm{E}$, Bull. Ipn. Soc. Fish. Oceanogr., Spec. Vol. (Professor Uda's Commemorative Papers), 1969.

Millard, R.C., W.B. Owens, and N.P. Fofonoff, On the calculation of the Brtint-Vlisitla frequency, Deep Sea Res., 37, 167-181, 1990.

Montgomery, R.B., Circulation in the upper layers of southern North Atlantic deduced with use of isentropic analysis, Pap. Phys. Oceanogr. Meteorol., 6(2), 55 pp., 1938.

Philander, S.G., El Niño, La Niña and the Southern Oscillation, Int Geophys. Ser., vol. 46, 293 pp., Academic Press, San Diego, Calif., 1990.

Philander, S.G., and Y. Chao, On the contrast between the seasonal cycles of the equatorial Atlantic and Pacific Ocean, J. Phys. Oceanogr., 21 , $1399-1406,1991$

Philander, S.G., D. Halpern, D. Hansen, R. Legeckis, L. Miller, C. Paul, R. Watts, R. Weisberg and $M$. Winbush, Long waves in the equatorial Pacific Ocean, Eos, Trans. AGU, 66, 154, 1985.

Qiu, B., and M.J. Joyce, Interannual variability in the mid- and lowlatitude western north Pacific, J. Phys. Oceanogr., 22, 1062-1079, 1992.

Quinn, W.H., V.T. Neal, and S.E. Antunez de Mayolo, El Niffo occurrence over the past four and a half centuries, J. Geophys. Res., 92, 14,449. $14,461,1987$.

Reid, J.L., Intermediate waters of the Pacific Ocean, Johns Hopkins Oceanogr. Stud., 2, 85 pp., 1965.

Rhines, P.B., and W.R. Young, Homogenization of potential vorticity in planetary gyres, J. Fluid Mech., 122, 347-367, 1982.

Rual, P., Courants Equatoriaux Profonds, Deep Sea Res., 16, 387-391, 1969.

Santiago-Mandujano, F., and E. Firing, Mixed-layer shear generated by wind stress in the central equatorial Pacific, J. Phys. Oceanogr., 20, $1576-1582,1990$.

Talley, L.D., Potential vorticity distribution in the North Pacific, J. Phys. Oceanogr., 18, 89-106, 1988.

Toole, J.M., E. Zou, and R.C. Millard, On the circulation of the upper waters in the western equatorial Pacific Ocean, Deep Sea Res., 35 $1451-1482,1988$

Tournier, R., Variabilite de la structure thermique et des courants a l'Ouest et au centre de l'océan Pacifique tropical de 1979 a 1985, Thèse de Doctorat, 154 pp., Univ. de Paris VI, 1989.

Tsuchiya, M., Upper waters of the intertropical Pacific Ocean, Johns Hopkins Oceanogr. Stud., 4, 44 pp.; 1968.

Tsuchiya, M., Subsurface countercurrents in the eastern equatorial Pacific Ocean, J.Mar. Res., 33, supp., 145-175, 1975.

Tsuchiya, M., R. Lukas, R. A. Fine, E. Fíring, and E. Lindstrom, Source waters of the Pacific equatorial undercurrent, Progr. Oceanogr., 23, $101-147,1989$

Webster, P.J., and R. Lukas, TOGA COARE: The Coupled OceanAtmosphere Response Experiment, Bull. Am. Meteorol. Soc., 73 1377:-1416, 1992

Wyrtki, K., Equatorial currents in the Pacific 1950 to 1970 and their relations to the trade winds, J. Phys. Oceanogr., 4, 372-380, 1974.

Wyrtki, K., Fluctuations of the dynamic topography in the Pacific ocean, J. Phys. Oceanogr., 5, 450-459, 1975.

Wyrtki, K., and B. Kilonsky, Mean water and current structure during the Hawaï-to-Tahiti shuttle experiment, $J$. Phys. Oceanogr., 14, 242-254, 1984.

Y. Gouriou, IFREMER, Centre ORSTOM, B.P: 70, 29280 Plouzané, France.

J. Toole, Department of Physical Oceanography, Woods Hole Oceanographic Institution, Woods Hole, MA 02543.

(Received May 8, 1993; revised August 11, 1993; accepted August 13, 1993.) 